Portland State University

PDXScholar

1972

\title{
SADDAS; a self-contained analog to digital data acquisition system.
}

Walter Anton Petersen

Portland State University

Follow this and additional works at: https://pdxscholar.library.pdx.edu/open_access_etds

Part of the Computer and Systems Architecture Commons, and the Data Storage Systems Commons Let us know how access to this document benefits you.

\section{Recommended Citation}

Petersen, Walter Anton, "SADDAS; a self-contained analog to digital data acquisition system." (1972). Dissertations and Theses. Paper 949.

https://doi.org/10.15760/etd.949

This Thesis is brought to you for free and open access. It has been accepted for inclusion in Dissertations and Theses by an authorized administrator of PDXScholar. Please contact us if we can make this document more accessible: pdxscholar@pdx.edu. 
AN ABSTRACT OF THE THESIS OP halter Anton Petersen for the Master of Sclence in Applied Soience presented May 17, 1968.

THtle: SADDAS, a Selfucontained Analog to Digital Data Acquisition System.

APFROVED BY MEMBERS OF TTE THESIS COMMITTEE:

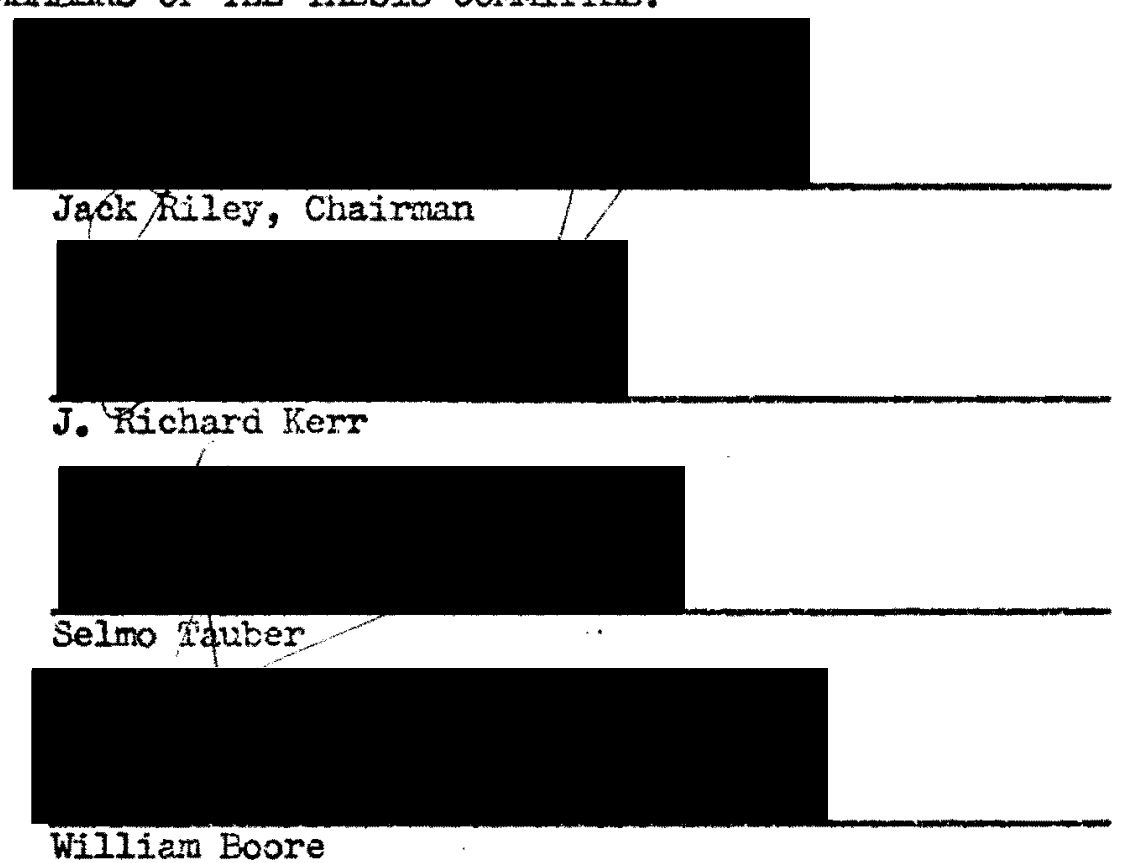

SADDAS, a Self-contained Analog to Digital Data Acquisition System, converts analog voltage inputs to formatted BCD (binary coded decimal) digital magnetic tape. SADDAS consists of a 16 channel multiplexer, a 17 bit ( 4 digits + sign) 40 microsecond analog to digital converter, a $5: 2$ byte 8 bit core memory, a 30 IPS (inches per second) disital tape recorder recordirg at a density of $556 \mathrm{cpi}$ (characters per inch), and a controller which integrates these instruments into a flexible and easy-to-use system. Sampling rates in excess of 360 sarples per second may be used when converting seven charnels of data, such as IRIG (Inter Range Instrumentation Group) analog magnetic tapes. 


\section{SADDAS}

a

SELF-CONTAINED ANALOG TO DIGITAL DATA ACQUISITION SYSTEM

by

WALTER ANTON PETERSEN

A thesis submitted in partial fulfillment of the requirements for the degree of

MASTER OF SCIENCE

in

APFLIED SCIENCE

Portland State University

1972 
TO THE OFFICE OF GRADUATE STUDIES AND RESEARCH:

The member's of the Committee approve the thesis of

Walter Anton Petersen presented May 19, 1972.
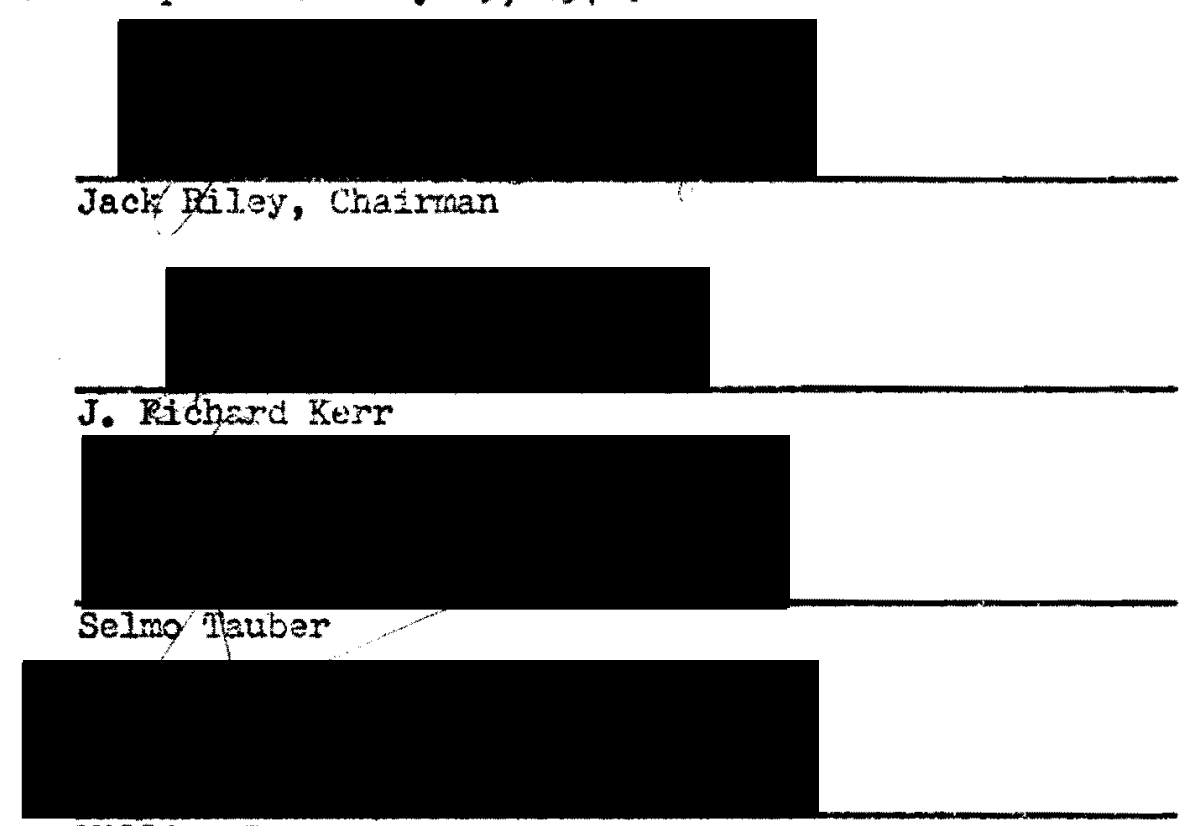

William Boore

APPROVED:

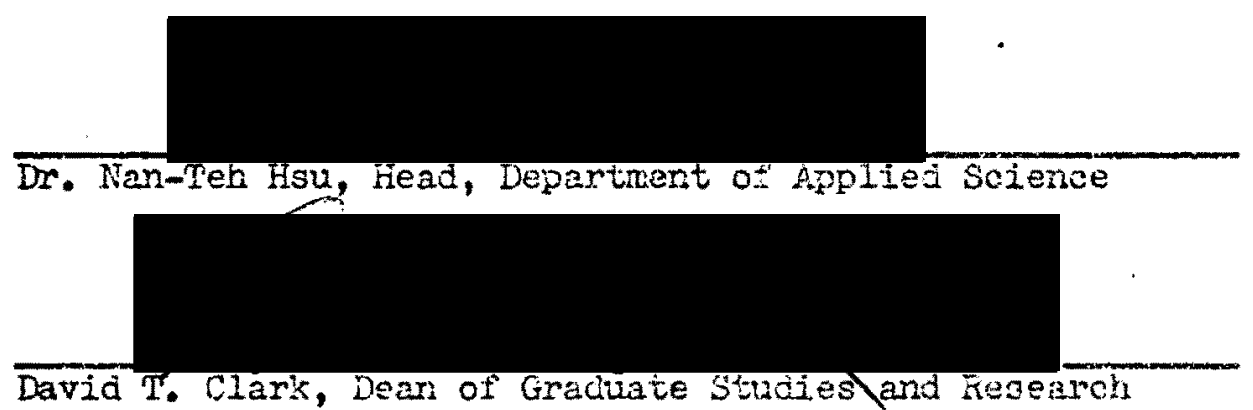




\title{
SADDAS
}

a.

SELF-CONTATNED ANALOG TO DIGITAL DATA ACQUISITION SYSTEM

by

WALTER ANTON PETERSEN

\author{
A thesis submitted in partial fulfillment of the \\ requirements for the degree of
MASTER OF SCIENCE
in \\ APPLIED SCIENCE
}

\section{Portlend State University 1968}


TO THE OFFICE OF GRADUATE STUDIES AND RESEARCH:

The members of the Committee approve the thesis of Walter Anton Petersen presented May 17, 1968.

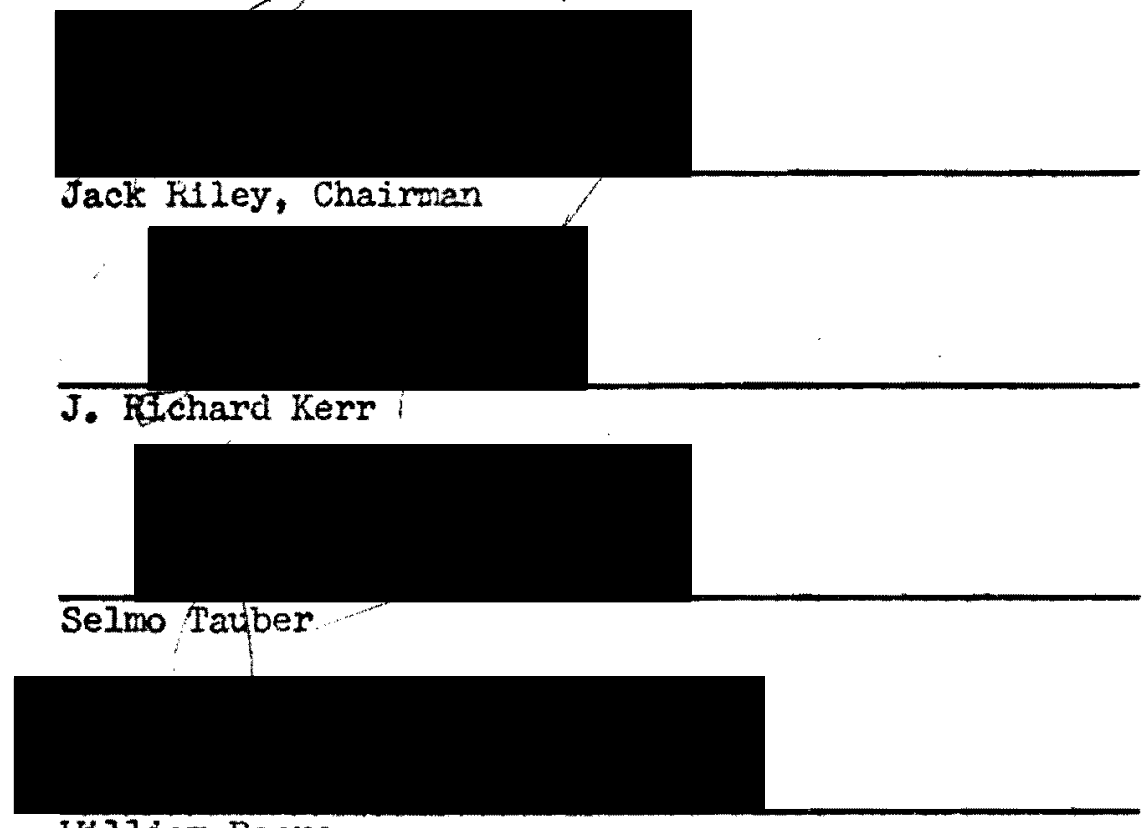

William Boore

APPROVED:

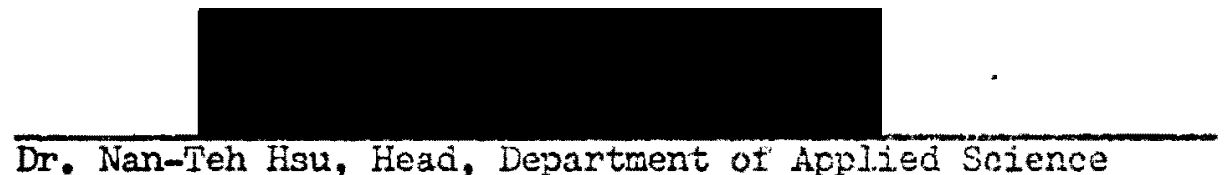

Dr. Nan-Teh Hsu, Head, Department of Applied Science

David T. Clark, Dear of Graduate Studies and Research 


\section{ACKNOWLEDGEMENT}

The Research Instrument Service of the University of Oregon Medical School made important contributions to this project, especially in modification of the ASR-33 Teletype for parallel output and in the construction of the interface between the tape recorder and the Storage Access Channel (SAC) of the IBM Computing System. The author is also indebted to Mr. Dwain Reed of the Department of Physiology for his patient work in troubleshooting parts of the system and in cabling (and recabling) the rack on several of the system components. It is aiso a pleasure to acknowledge the continuing moral support of Dr. John M. Brookhart, Chaiman of the Department of Physiology, who as principal investigator of USPHS, $\mathrm{NJH}$, Grant NB 04744 articulated the need for and acquired the funds for the development of the SADDAS system.

Iastly, I would like to thank the faculty of the Applied Science Department of Portland State University, particularly Dr. Harry White, Dr. Nan-teh Hsu, Lr. Selmo Tauber, and Mr. Jack Riley for their contimed patience and encouragement over lo these many years. 
TABLE OF CONIENTS

PAGE

ACKNOWLEDGEMTIS ....................... ili

TABLE OF CONTENTS ......................... iv IIST OF FIGURES ......................... v viii INTRODUCTION .......................... 1

Background ........................ 1

Design Considerations ................... 2

THE "SADDAS" DATA ACQUISITION SYSTEM . . . . . . . . . . 5

System Philosophy . . . . . . . . . . . . . 5

Collecting Phase ................ 7

Editing Phase ................ 7

Converting Phase ............... 8

Processing Phase ............... 10

System Component Selection ................ 11

Multiplexer and A/D Converter .......... 13

Buffer Memory ................ 13

Digital Tape Recorder ............ 15

Alphamumeric Annotation ............ 17

Control and Formatting Electronics .......... 19

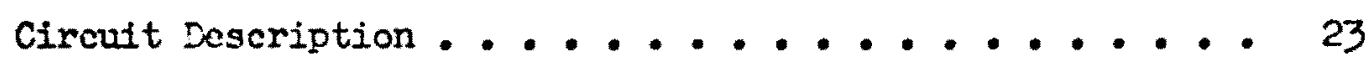

Block Dlagram ............... 23

General Concepts ............... 24

Circuit Card Functions .............. 30 
PAGE

Card A - Record Length Counter and IR Gap Generator 30

Card B - Synchronizer and Coincidence Generator . . 31

Card C - Start/Stop Control and clock ...... 32

Card D - Data Sampler and Shifters . . . . . 33

Card E - Magnetic Tape Formatter ........ 34

Card F - Unload Address Counter . . . . . . 35

Card G - Ioad Address Counter . . . . . . . 36

Card H - Memory Interface . . . . . . . . 36

Card I - Memory Formatter ........... 36

Card J - Multiverter Interface . . . . . . . 37

Card M - Light Drivers . . . . . . . . 37

Card N - Error and Status .......... 37

Card S - Tape Record Interface ........ 38

RESULTS ......................... 40

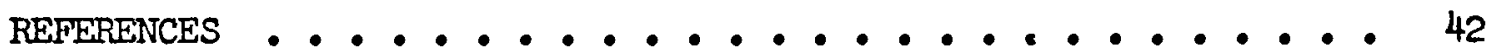

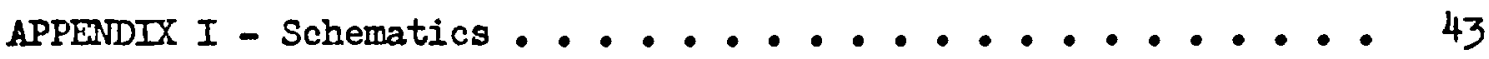

BLOCK DIAGRAM .................... 44

SCHEMTIC NOTES .................. 45

CARD A - Record Length Counter and IR Gap Generator . . . . 46

CARD B - Synchronizer and Coincidence Generator . . . . . 47

CARD C - Start/Stop Control and Clock . . . . . . . 48

CARD D - Data Sampler and Shifters .......... 49

CARD E - Magnetic Tape Formatter . . . . . . . 50

CARD F - Unload Address Counter . . . . . . . . 52

CARD G - Load Address Counter . . . . . . . . . 53 
CARD H - Memory Interface . . . . . . . . . 54

CARD I - Memory Formatter .............. 55

CARD J - Wultiverter Interface ............ 57

CARD M - Light Drivers ............... 58

CARD N - Error and Status ............. 59

CARD S - Tape Record Interface ............... 60

FP - Front Panel Lights and Switches .......... 61

BUFFER MEMORY ............................ 62

POWER SUPPLIES AND RACK POWER CABLING . . . . . . . . 64

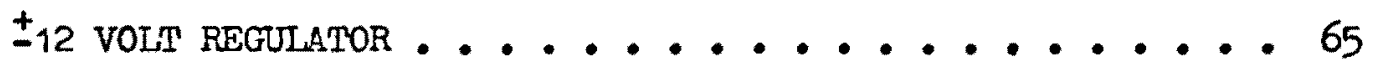

POWER SUPPLY - LTGHT DRTVER CARD . . . . . . . . . . 66

READ CAGE SWITCH - DATA - TTY - 1130 . . . . . . . 67

pulse gentrator Card .................... 68

APPENDIX II - Card Layouts and Wiring Lists . . . . . . . . 69

CARD A - Record Length Counter and IR Gap Generator . . - 70

CARD B - Syrchronizer and Coincidence Generator . . . - 71

CARD C - Start/Stop Control and Clock . . . . . . 72

CARD D - Data Sampler and Shifters ............ 73

CARD E - Magnetic Tape Formatter . . . . . . . . 74

CARD F - Unload Address Counter . . . . . . . . 75

CARD G - Ioed Address Counter ... . . . . . . . 76

CARD H - Memory Interface ............... 77

CARD I - Memory Formatter . . . . . . . . . . . 78

CARD J - Multiverter Interface . . . . . . . . . 79

CARD M - Light Drivers ................ 80 
vii

PAGE

CARD N - Error and Status ................ 81

CARD S - Tape Record Interface . . . . . . . . . . 82

FP - Front Panel Lights and Switches........ 83

APPENDIX III - Signal Cross Reference . . . . . . . . . 84

APPENDIX IV - Operating Procedures ............... 88 


\section{LIST OF FIGURES}

Photograph of SADDAS ............... Frontispiece

Figure 1. Data Acquisition and Processing .......... 6

Flgure 2. Data Record Formats ... . . . . . . . . 12

Figure 3. Comment Records, Tape and Computer Formats . . . . 18

Flgure 4. SADDAS output ................... 41 


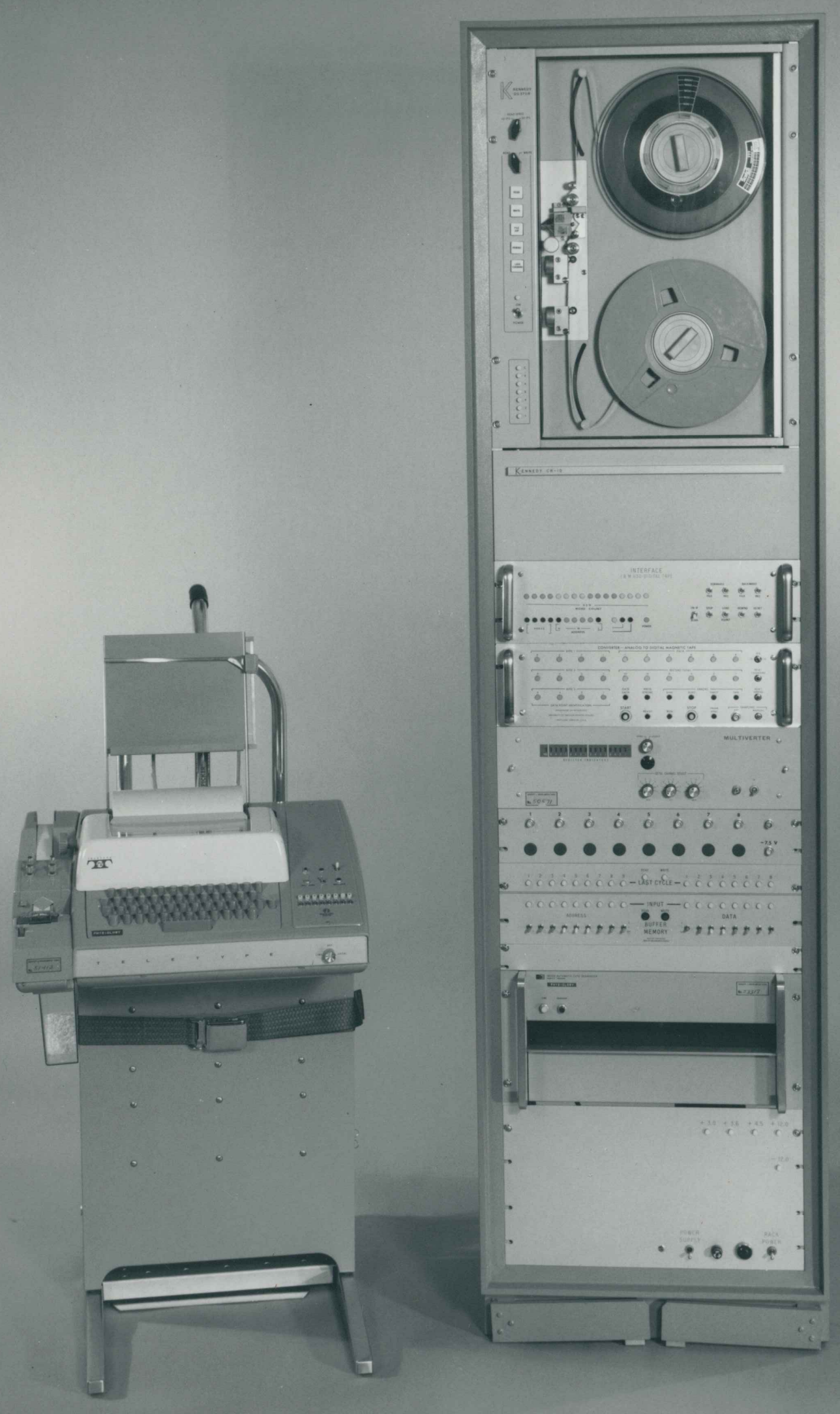




\title{
SADDAS
}

3.

SEIF-CONTAITD MAICG TO DIGITAL DARA AOUISITIOH SYSTEA

\author{
Walter A. Petersen \\ Department of Pinsiolos \\ Univonsty on Oracor recical school
}

IMPROTUCTION

\section{Facisround}

A few years aso a maicai researci team had great need of a multichanne? data accuisition and date processing system to investigate the neurophrsiological casis of postural control. Postural control resesrch us to that time was predorinantly cualitative in nature, in that the ray data vas mostly visual obsemation. Postural reactions elicited by a rariety of positional situations, either natural or imposed, iere cualitatively obsemed and recorded by shilled and decieavec investidetors. Fowover, they Iacied the tools necessam to do cuantitative postural cortrol rescarch.

Fechnoloeical acvenees brount ahout by rorid far II Iead to the development of scyoisticated reooritns equipment, servo systems, and corputers. Wth this amementerium the reseanchen could nor attacti posturel control mecheriems and its underlying neurophysiolocical basts in a giantitative faglion. Thus a new horizon in posturel control rescarch res opened un.

The essential vools for a cuantitative approach to postural 
control research and position, fonce, ard ande transcucers, mutichannel recording equipment, channel multiplexing and analos-todigital converters, and a digital computer fon data processing. Special transcueens nere conceired and built in the Uors Deparument of Phrsiolon. In rot tane recorcer capacle of recoring cherrels to a band with of 20 wlohewtz in the IrTg (Inter-zange Instinmentation (row) fomat wes on hand. Tacking vere analos-to-didital conversion ecuipment are a digital computor.

A suppiementary research grant application was made to an appropriate fecierai asency to fund these necessary tools. Although the grent rovier comittee recomised the novelt of the approsch and the merit ot the project, the recuest was not sully funced. The grantins asency felt, and fustiriebly so, that they had already funded several conputer instaliations in the viciniwy that vere not beins utilized to their allest capacity. Thenerone, they provided 20,000 to constuct on interiace to the then existing corputers - an IEn $1+10$ and an 318320 . The present thesis describes the evolution anc implenentation of this intenface -.. a seli-contained analog-to-diatid data acouis: tion gyster - SinDAs.

\section{Desion Consterentions}

The corputors initidy arailobie at not have electrical interfaces wich vere cinocty cocessbie to users. A direct tie-in to a computen's main Irame ros ceenec impractical, since jt ras felt that substartial enort vols be recuirec to install an interface rithout causing mutiple techiesl, practical, and legal probleme nith the 
computer, its othew users, and its manucturer. Mrenesore, a ver. early decision was male to have a univensal intersace to all cormuters by transferring the sata to the computer via binam coded decimal (30D) disital motid tape. Since the sotual interface to the computen would be ria comentional media, the problene hoperuliy rould be none.

Nor: that the basic neccis o: the resenchers had becn solvod, in principle at lesst, the conversion os soven track fil aralos data tapes to eeven track BOD fomattor difital tapes, consicionation ras Eiven to the ofhen usos that such a srotem might have in a medical researcis envinonmont.

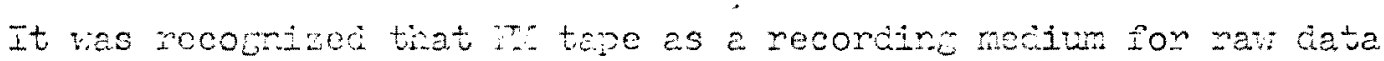
vas ganing in popuarity, and thorefone. it was likely that a nunew of othen investigators could nate use of an enalos-to-digital tape

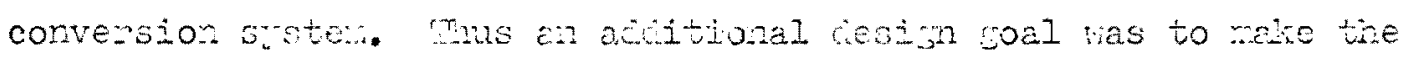
Systen easy to use, 23 rell es exsily aroilable, to all those tho necied such a caparity. Seconely, it was recomized that the system recuired soro mother oponsive, but ceneral purpose inswments, e.8.: an $1 / D$ (analos-to-cisital) converter, a core memony, and a

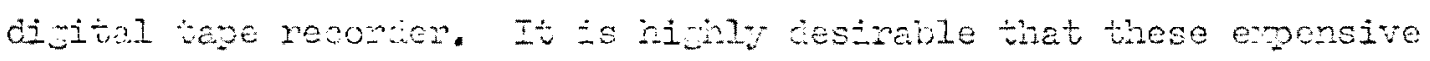
instmuments not be totaly dectected to a single data conversion syem tem, wh that they de uses non othen puposes as tell. Therefore,

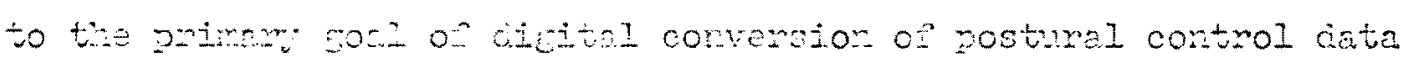

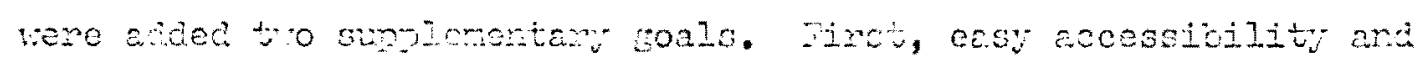

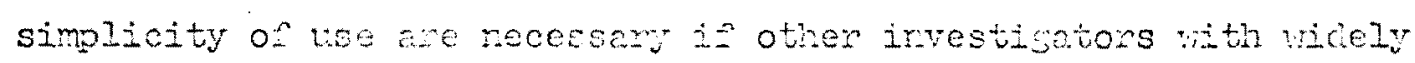
difrement probzers are to uso such a system epectively. Second, 
efficient lise of the ciollars spent could be made if the instmuento purchased hed a utility berond thet of their principal function as system components. The fulfillment of these latter boals cetemined in large part the selection of spcifia suster components constrained, of course, by consistonoy rith the basic systen philosophy. 
THE "SRDE" DATA ACOUISTION OYSTIA

\section{Srstem intiosophr}

The principal pupose of StDDS is the accuisition of data and its conversion to a form dicostable by modem diutal computers. In that conputer time is oponsive, it is very desirable that ouly neaningrul data be presented to the comouter. Thus, it is generally true that data rust be eritas (and/or concensed) if economical comouter opcration is to be achieved. Biolugical research, especialiy projects which are highly instmurental, cen easily enerate over-rholming amounts of rav data. rffective eciting of the rav data curing the conversion prooss is thereare essontial. This eciting phase is illustrated in Hidure 1 , Data Acquisition and Processins.

Fioure 1 aiso illustrates the position and rols of cata processinc in the cycle of research. Fiolosical hypotheses are embodied in researoh paradign - a mocol of that "migh" be true. Fperiments are desicned to prove on disprove the hypotheses by coliecting data wich hoperuliy cen support on roject the model. Discppointingly, often, the cieta orly reacly suponts on rejects the rypotheses. Given a clue, all-be-it small, the tenceious reseercher, rodifies his paradigm, asts a nore incisive cuestion, cesichs a nev experiment, collects rore catid, and thus stablishos a closed loop, on cyole, of research. Lata acouisition end processing are essential elenents of this loop and can ve conveniently describes, in Figure 1 , as four phases: colieatine, euitine, convertine and processing. 
COLLECTING

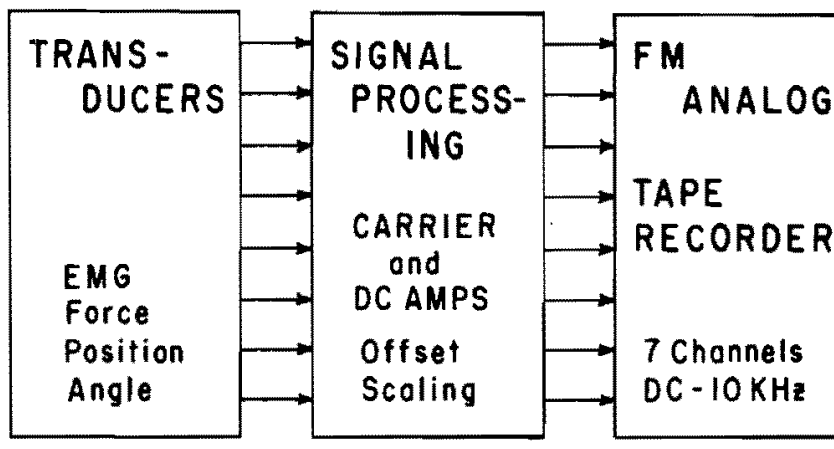

EDITING

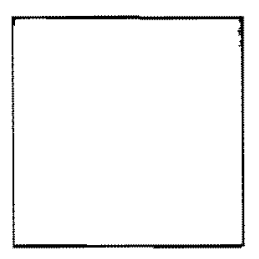

TELETYPE

ASR -33

alphonumeric editing

CONVERTING

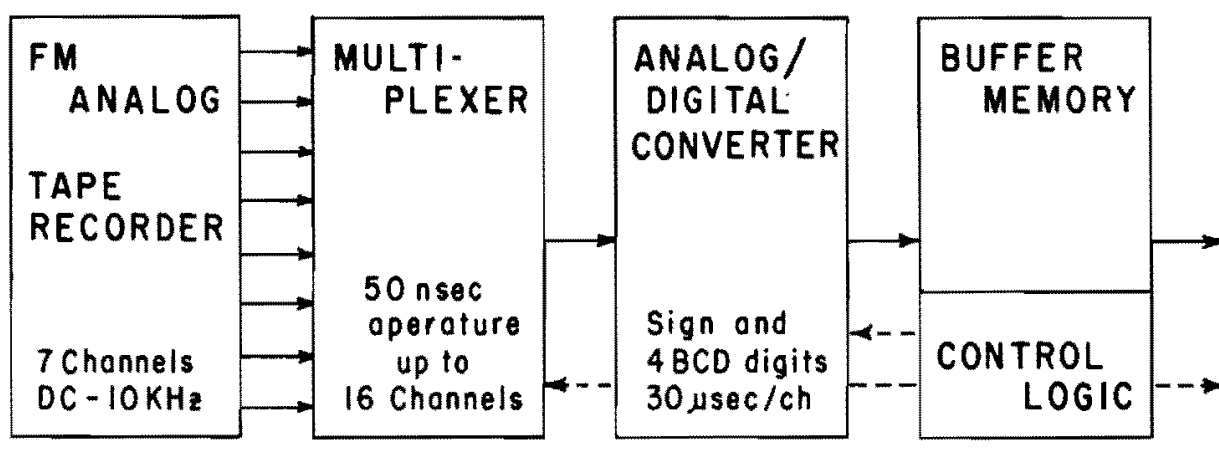

INCRE-

MENTAL and CONTINUOUS DIGITAL TAPE RECORDER 6 or $17 \mathrm{KHz}$

PROCESSING

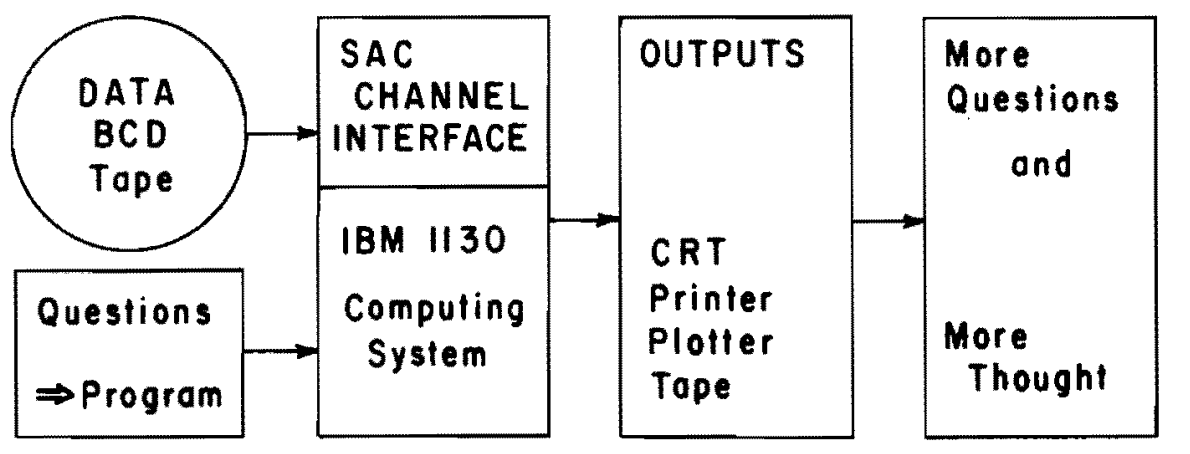

$B C D$

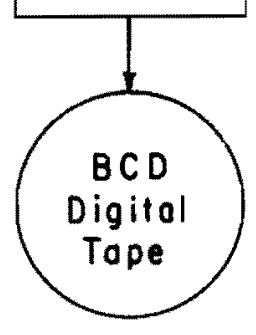

DATA ACQUISITION AND PROCESSING 


\section{Collecting pincss}

In the coliecting phase, ray data, hoperully manifest of the hypothisized uderlying paracigm, is captured. In the past, this vas usually a transient visual event and thus most often consisted in qualitative obsemation. Today sensitive instmuntation maies accurate cuantitative observations routine, and methocs of pemmenent reconcing maiss the cata accessible to many investicators and for years to come. Figure 1 schematically illustrates now the collecting phase consists ôे transcuction o $\hat{i}$ biological phenomena into electrical signals, and then the recorcine of those sicnals for subsecuent analysis.

\section{Ditin: Dlase}

As illustrated in figure 1, the editing phase appeans enpty and inconsecuential, but it is extremely important as it is the key to quality research. Simificant results are made manifest, not by averasins all data - both good and bad - , but by skilifully coirecting anc/or valicily excluding unreliacle data.

Jatins also consists of liening tract of the data and the conditions under anich it vas taien. For this reason SADDAS includes in

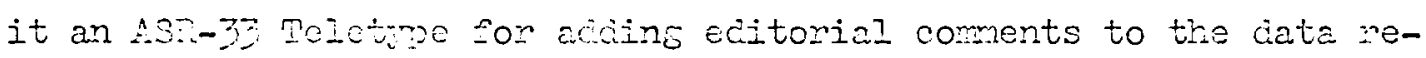
concis at the time of $h / 2$ conrension. BJ placing the dicital tepe reconder in the incremental mode, comments trped in via the Asi-33 Teletype keycond are mitten directly onto the digital marnetic tape as computer reaciale characters. 


\section{Converting Phase}

The corversion phase consists o: transforming the raw recorcied data into a form suitable for aralvses, or as labelled in Fisure 1 , processin: For hand-collectec cata, the conversion phase micht consist of drawing a histowran or craph. For SADDAS conversion means converting mltichanel continuous analos deta to sincle channel discontinuous distal data. This reruires sirultaneous trensionmetion of three Facets of the data - 1: numer of channels (7 to 1), a: form (electrical analos to ditgital bits), and 3: time occurrence (continuous to periodic bursts).

Channel conversion of 7 parallel injuts to one serial output is achieved rather easily by usine a muttiplever wich periocically scans all channels secuentially and semples for a brief noment ( 5 microscconcls) the ciata present on cach chemrel. Tho mitiplerer used in SADrAs can scen anci sample 25,000 times per second.

Conversion of electricel analow signals to digital bits is accomplished by an analog-to-cictal converter fith the suDhs converter, accurate conversion to $\varepsilon i m$ and sour difits is accorrolished in acout to microsecons.

The most difficult conversion to accomplish was the timing the aralog cata is cortinuous in time, the output of the $M / D$ corventer is contimuous inile conventing (although it changes, every 10 microseconds), ant the imput to the difitel tape reconder cannot be continuous. A convention in the comuter incustry is that computers reac magnetic tape in bloclis. Ablock (of records) is typically anywhere from 18 to 1096 characters in 2creti. To delimit blocks, an 
inter-record sap (InG) consisting of no deta for three-cuarters of an inch nust be mitten. The term "intermrecond gap" was coined in the industry's irfancy when a block typjoally consisted of a single record. Durins the time that an InG passes the difital recordine head, data cannot be raac or mitton. Thus thils an IFG is beine formed a dicital tape recorier cannot acost the sexial output of an A/D converter. For an illustration of Ire's refer to the langetio Tepe pormat cection of Figure 3. To solve this problem, a oufier memory is employed as a "catch-basin". Data from the $L / D$ converter "passes-through" (i.e., is written into and reac out of) the buffer memory on its way to the disital tape. During InG's lata is not "ead out of the nemory. Therefore, cata comverted curing the ING accumulates in the buffer memory. Then the tape recorcier can accept cata again, the acournulated contents of the memory are witten to tre trpe.

The size of the buffer memory cen limit the sarpling rate of the system. Since the bufier memory accumulates data cenerated curino IFG's, the dicitized date rate (samplins nate $x$ chamel number $x$ difits) mist not fill up the buffer berore an IDG is corroleted. The memory used in sonds is 512 S-vit butes. Each channel sampled vitilizes three bytes of memory. Thus, (if emor (dropped cata) is not to occur), onn 170 cat obmel samles can be occumulated during an

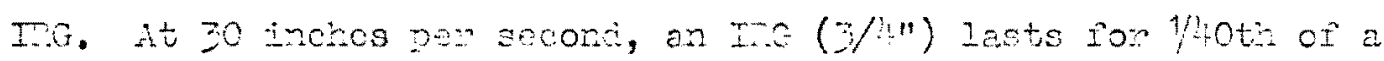
second. Thus the date rate Indit through the bumfer menory cue to accumulation curing Irg's is $40 \times 170=6300$ chemel serples (4 difits + sicn) per second. In terms of digital characters, this amounts to it $\times 6800=27,000$ cheracters per second which far exceecs the writing 
rate of the digital tape recorder usco in SADDis.

The digital tape reconsor utilized in SADDAS operates in both an incrementa). mode (for adding editorial comments from a teletype) and in a continuous rode (for recortins of the mitiplexed anc disitiad cata). At a tape speed of 30 inches per second and a recording density of 556 characters per inch, the poet roconting rate is 16,680 characters per second. The efsective rate is somewhat less cue to the cuty cycle factor imposed by the necessity for IrG's. This cuty cycle is a function of the block length: $D 3=3 I /(3 I+417)$. Yith the conventional aximum blocir lengti of 4096 , the ciuty cycle is $91 \%$ giving an effective reconding rete of 15,150 cherecters per second. of course, with shorter blocks, the entective rate is prosressively lover.

The smell blook calied cOITOI. LOGI is a controller and is the heart of SADDS. It controls the miltiplexer, the analog-to-cigital converter, witing to and readins from the bufer memory, the formatting of the digitized dava with the inclusion of data point identifiers, the ceneration of TRG's, and the operation of the tape reconcier. Details of this logic ill be discussed in the balance of this thesis:

Processing these

referring again to igure 1, the last phase in data acouisition and processing, is processing, or the actual analysis of data. mo principle elements hore are not instmuentation systems, such as SADDAS is, but cerebration and computational and data display assists, 
such as computers and fraphic cevices. In Figure 1, the cerebration is embodied in "Cuestions". These questions are articulated in the form of computer proesams inich manipulate and display the cata in a fashion that will hoperully manifest answers to the questions. Generaliy, the anstens senerate nore cucstions, which then recuire more thought and adcitional experimental desticns to elicit further answers. Thus, the cycle of research is closed.

As ultirately implemented, the cicital tape recorder vas also used to input ECD ta:pes to an IDS 1130 Computine System. The processing phase of Pigure 1 illustrates this somewat by having the BCD tape entering the SAO (Storege Accese CherneI) CHADEL THTRPCD of the IFI 1130. The control electronics for the operation of the disital recorder as a corputer tape transport and the electronic interface to the SAC CHADL is housed in the same electronics rack as the SADDAs, but is not actually an essential part of it. In the frontispiece, the tene control electronics and SAC interface is the rack (rith handles) imediately below the tape recorder.

\section{Systen Comonort Selection}

The digital aspects of the ciata conversion problem are illustrated in Fisure 2. Jach chamel of analos data is digitized into a 17 bit fCD format an an (anelog-to-ligital) conventer. This injormation mut tren be formetter and recorded into the six cata tracks of a seven traek diçital inagnetic tape recorder.

As discussed above, Picure 1 shows that the principle components of this conversion system are a rultiplexer, an $\mathrm{M} / \mathrm{D}$ converter, a 


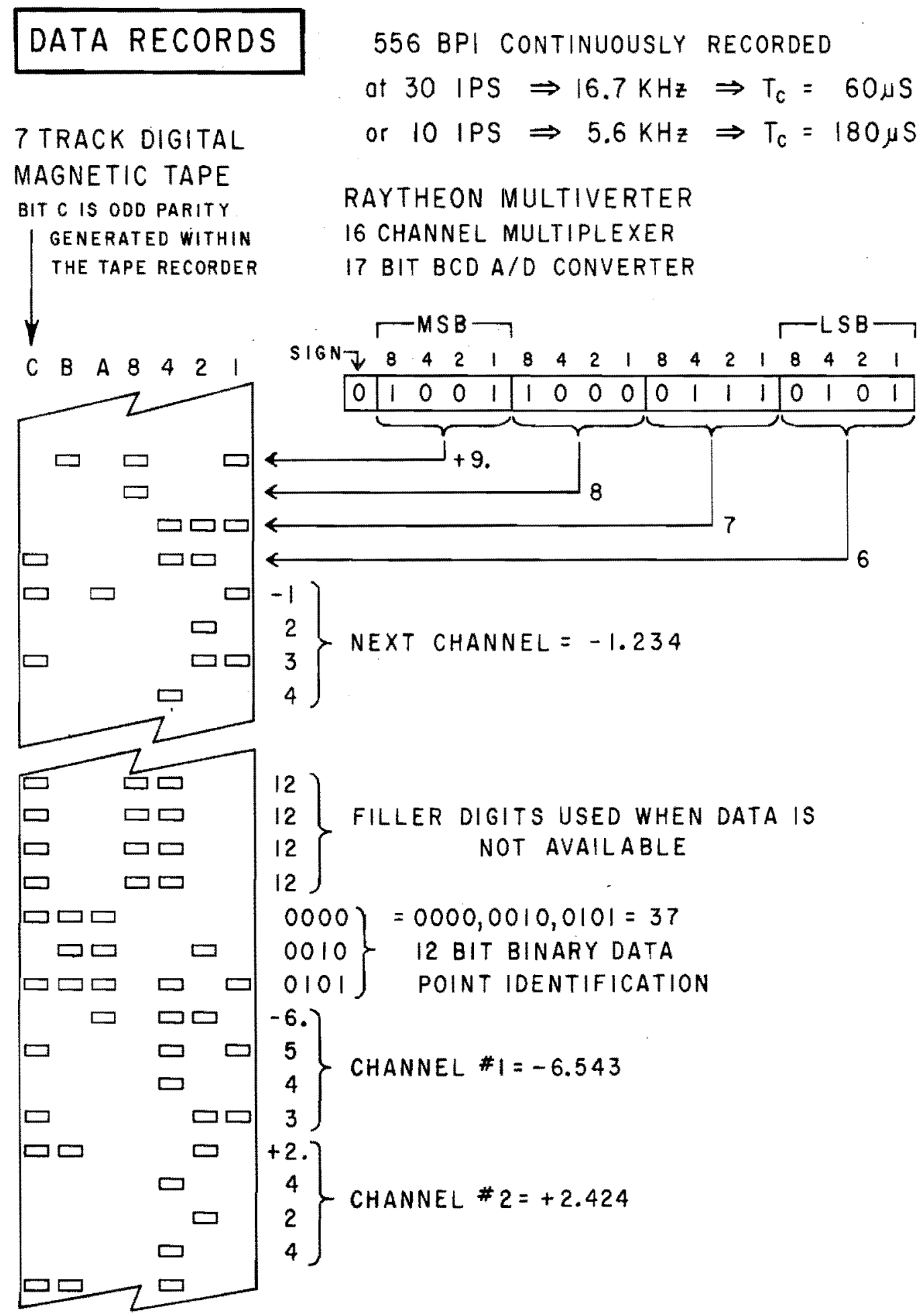

Flare 2. 
buffer memom, and a digital tape recorder, all of which were purchased items. The lowic for their control and the electronics necessam for format conversions, data icentification, and for the individual interfaces to the purchased units wre locally constructed with RT integrated circuits and a liberal spririling of discrete active and passitre components.

\section{Multzolemen $\mathrm{and}$ in Conventer}

The Raytheon Muliverter was attractive for this purpose because it performs both mutiplexins and conversion functions in only $51 / 4$ inches of rack height. Accuracy $(.01 \%)$, hish speed (39 usec for four decimal digits, 31 usec for three bigts), 16 analog inputs (expandeble to 96), anc cost (arount 7,000) vere all convincing reasons for its choice. Seven channels of three digit data can be converted in less then one-ruarter milisecond, wich jo essentially simultaneity for most biclogical cata. It is also useful for several other "uonsystem" purposes. "ith very minor nodifications to the circuitury of its rront parel incicatons, it can be mace to function nicely as a free-standing ECD digital voltmeter. Furthemore, it is intenced to form the anaios to digitol Iink in the eventual hyoridization of an analos computer to a smell disital corputer. Decause of these entra purpoes, a DOD rathen tisen a biram converter vas selected.

Fures:

As show in Figure 2 , the maximum continuous recordine rate of a 30 IPS (inches per second) digital recorcer miting at a ciensity of 556 BPI (bits per inch, longitucinally) is one character every 60 usec. 
Since the Mutiverter can procuce four characters in 79 usee, and may produce 6\% cheracters $(16$ charnels) in less than tro-thirds of a millisecond, it is clear that some sont of a buffer is needec to temponarily store the niltiverten data output wile the individual characters are rritten onto aigital tape. Furhermore, there is the digitai tave convention that demanes InG's and so there must be a data eccurulator curirs the "gen time" of a rocorcer producing computer reaciable tape. A 512 byte ( = 3 bits) ferrite core memory (n-12) manupactures. by the Ferrozcube Corporation semes this purpose very nicely. Reaciing or writine a byte in 10 microseconas, it can interleave the storage of a sutivonten data and the retrievel of that dota for iriting to the digital recorcer. Theoretically, 16,667 Nultiverter words (4 digits + sign stored as 3 brtes) could be stored and retrieved per second $(16,667: 3 \times(10+10) S=1$ second $)$. This is centeinly a sufficient amount of data points for virtually all biological phenomera. In fact, the data rate could be shared among eight or ter chanrels and the samplins rate vould still be sufficiently hich for rost bjological rosearch.

The riltiverter rond of Figure 2 is stored as three eight bit words in cone. The first von contains the sign and the most significent byte (1ree), the next vord, the next tro bytes, and the last word the least signilicant byte (ISS). There is room in the last word for a flaw inich insicates thet it is the last piece of date associated with a single sample bata comard. This flas is used to insems three characters of birary data point icientification into the dicital record, irrespective of the number of analos channels converted -- 3, 7, 
or 16.

Several adiitional uses aro plannei for the core momom. In conjunction with the Multiventer and several $\mathrm{D} / \mathrm{A}$ (dintel-to-analos) converters, the mewom aill be used as a very flexible time delay cenerator for the analos computer mentioned above. Tith little additional electronios, it iil be shle to provice simutaneously several celeys of different curetions. The memory till play an importent role in an off-line system fon plotting digtal computen cata. Short secments or plottirg instiuctions (such as rould be sent to a Calcom incremental plotter) :ill be read into the core from the playback electronics of a tiftel tape recorder, wich would then halt. The plotting instructions rould se taken from the core at a rete corpotible fith the mechanical plotter. The core would then be reloaded ith further commans by reading another plotting recond from the tape recorder.

Disital Tape Feconer

The primery specipication that the tape reconer must meet is an average riting rate of 0.1 kilochanacters per second. Mis ficure us emrived to consicering the rost extreme data rate to co expected of the postunel cortrol experiments. The postural stimuli ane risplacements of a plation on wich nomal cogs are quietly stanting. Thein reactions to the displacements constitute the date. of the postumal control erostumts. Meso date are sencrally re-

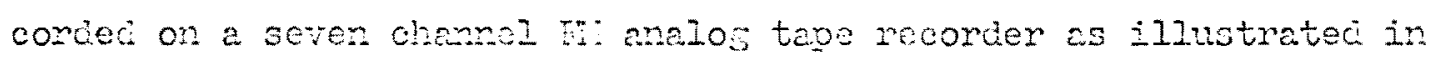
Micume 1. Visual obsemation of nany dogs confims that coms nill not tolerate furdamental frequencies in ercess of 3 herte. For cach 
fundamental erele it is most cesirable to recorc 120 data points (z: phase resolution and frecuercy components to almost the seventh rarmonic). If this were done for each of seven channels and four tape characters icre rocuired for each cata point (four bigits itith a sier "overpunches" by setting the $A$ or $B$ bit), the cata rate rould be 3 $\times 120: 7: 4=10,030$ cheractens/second.

Since his speed tape iransports and low cost are not bedfellons, a mecilum spaed (30 IPS) transpont (Nennedy Company's DS370R) has selected for the difital recordins iot. The 10.1 tilocharactens per seoond requirenent dictated a bit density or the tape of 556 EPI. This combination gives a peak deta rate of $16.7 \mathrm{KC} /$ second, but the averase rates are sonerhat belo. this dependent upon recording block size. Nost of the anticipated data rates are substantially below this, so a slover rate o: $5.6 \mathrm{xo} / \mathrm{second}$ is also avalable via a tro spect capsten motor, wich operates at 10 IPS, as well as 30 IPS.

Generally, it is desimable to annotate the data records ith some sort of a iritten coments, such as vould be enterable fron a Teletype keycoem. Therefore, ax incremental transport vas chosen for the cigital recording job -- it could hencile both the high cata rates by opondins continuousy via a expten, and also could rrite coments asmchronousy with an incremental stepping motor. mhis inencmertal moce ts 2 lso weful for very lon data rates, where the asymohonous rate is below the ravimu stepping rate of zoo per second.

Althoun the initial concept of the conversion systeri cid not recuire playoack or the digital tapes, read electronics vere pur- 
chased along ith the tape transport. The principle reason for this vas to inemponsively implement the offline digtal plotting system mentiored above. It tumed out that this was a very fortuitous ciecision, as it ras subsequentiy recessary to use for cate prosessing a computer that diti not have a rametic tape transport. Thus that started out to be a rite on:" incremental sepe reconcen is nou funetionire as vell as a low buty computer tape unit. The actuel interface vas mece to an IEN 1130 yia its Storage Access Chamel (see SAC, Fisure 1).

\section{Alphemumenic Amotation}

Vany huncreds of exocrinents vill be uncertaken in the postural control stucies. The rametic tape format dosired for these cata is illustrated in Figure 3. Wach experinent is bracieted of $\hat{x}$ by tape maris, i.e., LOF's. Annotations to the cata are recorded as heacer and trailer recoris. The heacier record consists of infomation such as -- the cate, an experiment icentification number, the troe of experiment, transcucor scale factors and oftesets, the sampling rate of the conversion, etc. The trailing recond might consist of specific conversion iniormation, such as the number of data points senplec, the number of magnetic tepa records reitten, and anrtring else the investifaton may have thought about during the conversion.

By operating the tape recorcier in an incremental moce, it is possible to end comment reconds to the difitai tape in an asyncimonous

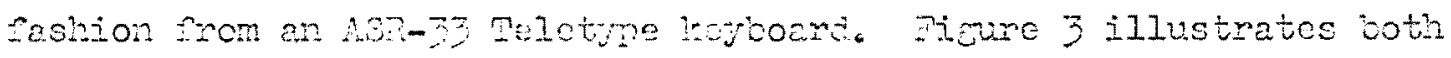
the method of annotation and the cotails of the coding schome. Bastc- 


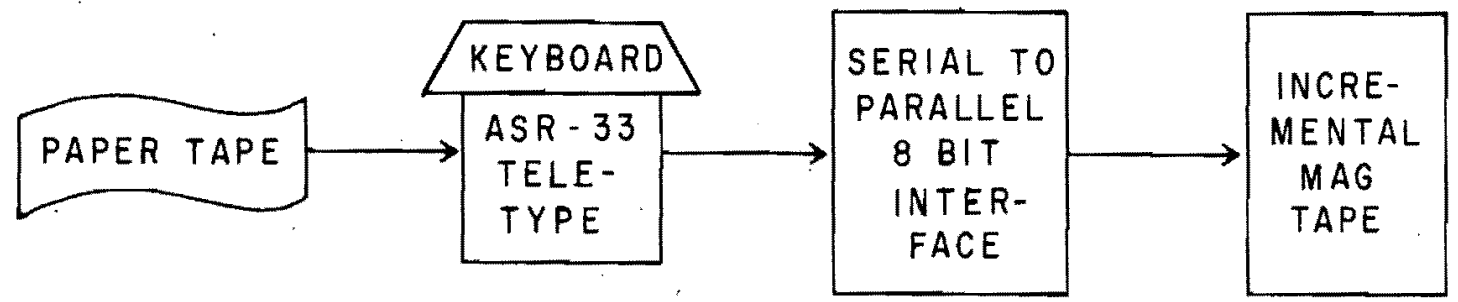

THE SIX BITS OF A MAG TAPE WORD ALLOW 64 CHARACTERS. ONLY THE ALPHAMERIC CHARACTERS OF THE ASCII CODE ARE RECORDED BY USING ONLY THE LOWER SIX BITS AND DEMANDING THAT BITS 6 AND 7 BE MUTUALLY EXCLUSIVE.

MAG TAPE

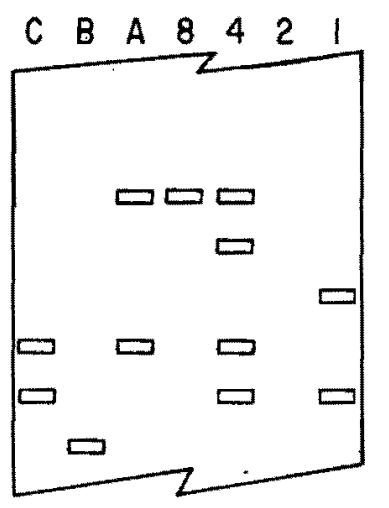

ASC II CODE

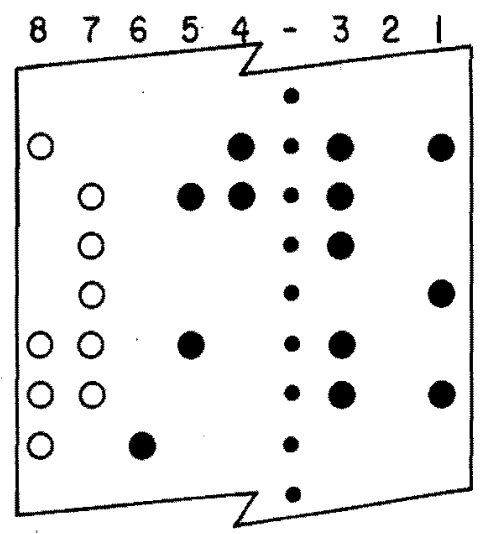

MAGNETIC TAPE FORMAT

EXPERIMENT \#।

EXPERIMENT \#2

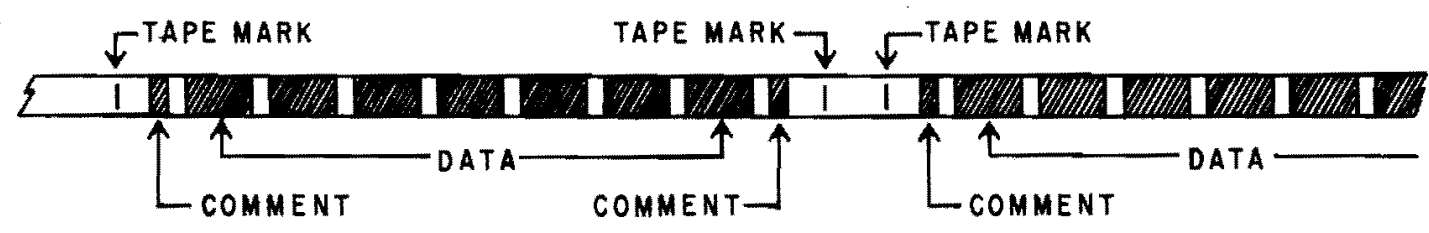

COMPUTER WORD FORMAT

MAG TAPE IMAGE

Fisure 3. 
ally, the first six bits of the ASCII Smorican Standard Code for Information Interchange) cocle are recorcied into the six data tracks of the seven track magnotio tape.

Selotyse wits operate soriely win the nexis and spaces of the coce being simalies by the suesence on abscnce of current passing through tise unit. Sinco a bititel tope reconcen recuires paraliel information as input, a Televpe unt is rot cirectly compatiolo With it. Therefore, a serial to panalel conversion must be exected betreen the tro units. A mocel AST-33 relotype vas mocipiec to provice parallal operation compatible vith NTL logic used throughout the SADDAS electionics.

Contirol and Tomattine nectronics

The integration of the nultiventer, buffer neromy, and distal tape reconcer into the SADTAS system is accomplished by an electronic log package (a controller) that was specifically designed fon this task. The heant and brän of SADDAS, the controller, is illustrated in the Prontispiece as the second rack vith handes below the tope recorder. A nore cetailed illustration of its sront panel may be found on the last pase of lppendix II: Front panel lichts anci Sritches. For a sirplizied blodi diagram of its operation, vever to

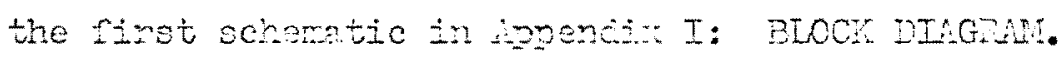

The basic desin coal has to have a conversion system that ias. extremely easy to openate. Whe extent to rinich this goal was met can be juiges by the golloring operatins instmotions:

1) Tum the system porer oN. 
2) Select DAR mode (other options are TiLrYPa mode and CCIPUTH mode).

3) Place the tape recorcer into the mode and select 10 or 30 IS3.

4) Select on the front of the rultiverte: the number of analos chanuels to se comerted ( to i6).

5) Set the samplins rate generaton to the desirec number of scmples/socons.

6) Cheot that the IPS sutith on the controller corresponkis to the Ins sititch on the tape reconter.

7) Push the controllew STMI button to initiate data conversion and the rriting on the dicital tape.

8) Push the controller STOP bution to cease data corversion and to bind the tepe reconder to a halt.

Briefly, the secuence of events curing cata conversion is as follo:s: The controller and the computer intercace share the same poiter supply, as they are never operated simultaneously. Purthermore, they both can control the tepe recorces. The selection of the DnMA mode (a suitch installed in the mepe Feconer electronics rack) gives poren ard tape cortrol to sabns's controller. It also comnects the dotu outputs insm the forratting electronios in the controlien up to the tapo moonem irpuss, nne also renoves from these inputs the parsilel cata outouts from the Telotrpe rinich are used. during the incrementel (TISTPS) rode of operation.

The parametens of the conversion, $1 . e .$, the tape speck, the number of andog channels to be converted, the sampling rate, when to 
start and wen to stop ane 311 detemined sy the data and the interests of the investisator. Theresone, 3400s cannot mate these deciatons for him. Fovever, once he has made his choices, the actual conversion process automatically.

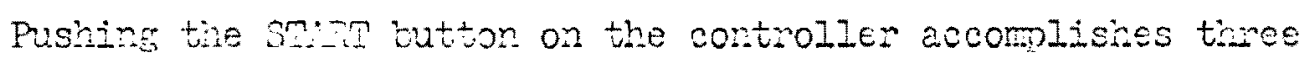
things: 1) it pesets all os the counters, emror indicators ard comat secuencens, e) it allors semping comands to pass to the maltivente: and i) it starts the manevic tape tmansport movin: ith an initial invermecond sop. On ecch conversion secuence or the Inltivertem, the core memow is secuentially loacod with the converted data. Lacir of coincicience betreen tise loading and unloscins core adress counters is an incication thet thewe is information ir the core memow that has not been transcriber onto the monetic tape.

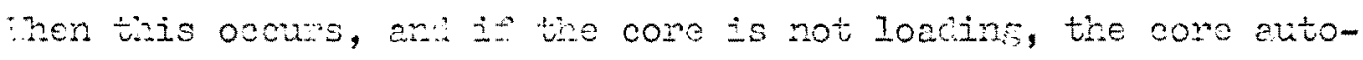
matically unlocs the information secuentially into the InG IAPI

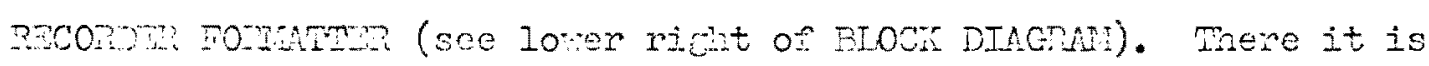
formattod and ratten on to he distal tape at a peak rate of eithon 16.7 or $5.6 \mathrm{ic} / \mathrm{second}$. menever the last cheracter of the last channel of a sample point occurs (the conc lemony rord is rlased for this), the formatter inscrto as tiree characters a 12 bit lata point icentification mubet. Periocicaily, the tape reconder catches up to the cate output of the ultiverten. At that time unioarine cosses and a fillem dit (a binam i2) is miver onto the magnedic tape (see Pioure 2). Irtewrecons gope (a lonjituinal check character and trmoe-quentone of on inch of unzomely saturated tope) are insented automaticaliy after a specinjec rumber of characters, both data and 
filler digits, have beon mitton. The mober of characters, i.e., the record length is seleotable $\mathrm{by}$ sitches that are immodiately behind the front panel of the controller. Nomally, this numiver is 1006 , but $j$ is setale amene from 1 to 1096.

Pushing tie SPor button removes the samle and convent comands from the lultironter, and thus no more data is loeciod into the coro memory. Then all of the cone load has cen transcribed onto the nasnetic tage, there is probebly a substantial pontion of a tape record Iest. mis is filled ith siller jisits, and the transpont comes to a halt at ine rext intermeoond gep. The investigator then has the option of plecing an end-o-file mare ( $\mathrm{O}$ ) on the tape, or incre-

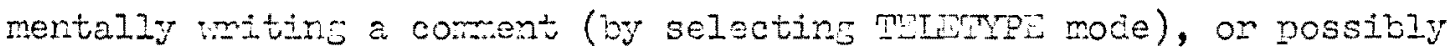
changing the conversion parameters and continuing to convert data. Fow ease of constuction art maintenance the SADNS controllen is made out of foun by five inch circuit eards which plus into a cage of soctetis acci-rowited behind the controlier's front panel. The incivicual camo are mosty socket mounted RaL integnated circuits uith some aduitional semicondictors anc passive components. Connections on the cerds rene make in a point to point rashion lith teilon covened ine. iumerous test points and status lights vere included in the desim, so that any mantenance recuired could be speeniy done. 


\section{CTMCUTR DESTIPTIOTS}

\section{Bock Diamaw}

The SAN21S 3loc: Diasran is an attempt to simply and schemetically relate the multitude of comeations (approminately the mior corponente and furctional elements of the system. On the Iowth, Eest, "est and Bouti on the logio carcis are, respectively, the nltiverter, the core renom, the cisital tase recorder, anc the controjlen's front panel. We finst three compononts are free stercins units (i.e., not part os the controller) and are suitably cisplayed as bole blocts. The Serpling Rate Generator is seni-bold as it is a necessary (ut eztomal) itom. Thero is a selectaic 1, 10, and 60 herta pulse eneretor aveilable on the porer suppiy racir, which is used rostly for systen test. Jomally, for data conversion purposes, a smell bonoin top pulse enerator (Pertronin 114) is used.

In the conter of the bloc's diagnam, the najor logic circuts are given functional names. The letters in the upper-right hand corner of these blocis signify the logic card or which the circutt nay bo round. The broac lines on the sices of these sunctional blocis Meys them to thair closost relatac system comonent (iv, $\vec{E}, \mathrm{~S}$ or it).

Paraliel date poths ene shom as two lines with hala-head arrous and an intorvanis murer stating the nurber of perallel paths. If

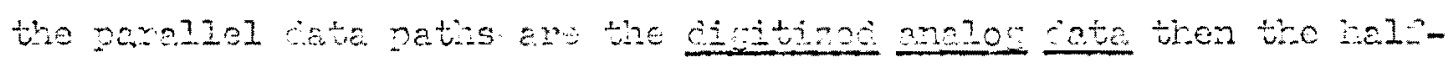
anores lines aro bolc, othertide tiner aro thin-ined. Control end status inionation are shom viti full-heaced amois. Direct control ratos solid lines, ijile incirect control, fectiback, and status are only ciashed lines. 
General conoents

The electrorics in the controller of SADDAS performs two ceneralized furctions:

1) Interacing to and bet:een the electronics of the other system corponerts and

2) Sequencins all of the sister components so that the right sicnals, and only the risht signels, occur at precisely the right times.

Function i) is relatireiy easy to achieve, in that all that must be done is to keop track of polarities, voltaee levels, ourrent requirenerts, inpedanees, the cetails of proper grounc, and shieldine. Function 2) is substantially more difficult in that there is a great ceal of interaction between the system components - certain simeis mat be generated after specific events, but only if certain concitions are met, etc. The difficulty of the two tasks might be linened to staching bricks as compared to jussling bricks. To help understand the "jugeling act", the following concepts should be bom in minc.

Any procecure consists of three parts - a beginnine, a micile, and an end. In control instumentation, eircuitry is designed to do those tesks wich are necessam during each of these periocis. In the case of satas, at the beginning countens and shift registers nust be initialłzed, and the ciejeital reconder must begin noving tape. During the micile, aralos cata must be sampled, disitized, accumalated tomporarily in the bufer memory, retrieved, fomatted and written to the tape recorcer - all in a coordinatod fashion. At the end, data 
sampling must stop, the romaining accumulated clata must be written out, and the tape transport broucht to a halt in the conventional fashion.

The circuitry essociated rith starting and stoppine a conversion can be unclenstoon if the characteristics of the mltiverter, buffer memory, and tape recorder ars inown and by some dilisent study of the SADDAs schematics. Horeve:, the circuitry mich coorcinates data semplins, converting, Eccumilatine, fometting and miting to the tepe recorder recuires some adcitional explanation.

Basically, there must be coordination between two asynchronous timines - the sampling rate aplied to the wltiventer, and the witine rate clock for the tape recorder. This problem is compounded cy three additional factors. The distization rate of the huliverter (appro:irately io mioroseconcs pen difit) erceeis the chanecter mate of the tape recorder (60 microseconds). Secondly, the tape recorder cannot continuously record we to the requirement for IRG's. Lastly, the 17 bit distized output of a iultiverter chamel input must be reformatted into the siy data bits contained in a seven track tape recorder character.

The electronic solution to these problems follows: As each chamel is semoled and digitized, whe 17 bit output of the lultiverter is placed in a 17 bit holding register on Card. These 17 bits (a sten and four 2isits) are subsecuently fomatted sor the merrony and the tape reconder as follon: 


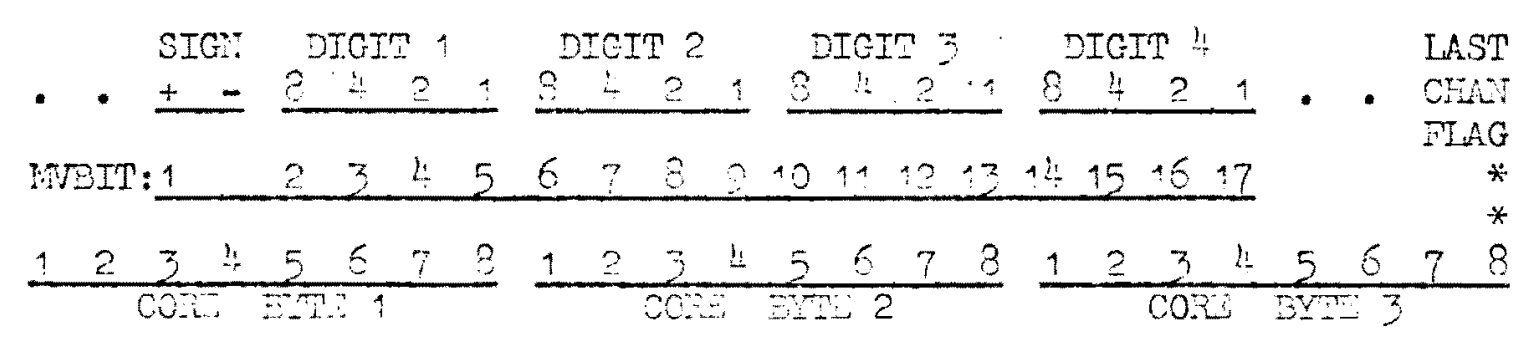

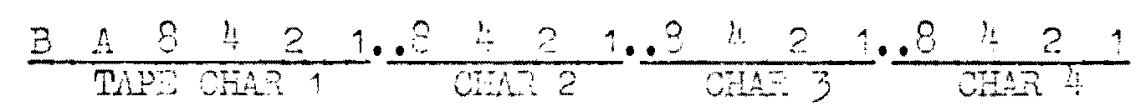

For loacing Into the core nemory card I formats the 17 bits into

three 8 bit brtes -- the stgr enc lSD (most significant digit) into

the first byte, the nert tro digits into tise secord byte, the last

digit and an end of sample flag into the last byte. A plus sin is

coded as a heridecimal 2, and the negative sign as a hexidecimal 1 ,

and it occuss only on the last ohamel of any samole set. These

three bytes are selected (i.e., connected from Card I to the burier

memory's interface on Card $H$ ) and then loaded sequentially into

memory by a three bit sinif register (U7, UO, U13) and IOAD circuitur

on Card D. This secuence happens for each chamel of a sample set in

an unbroken fashion; that is, the burer memory is totalli cedicated

to loadins when iultiventen conversion is in process.

On Card $B$ there is an adiress coincidence circuit wich detects non-coinctdence of locing and unloedire adiresses. This occurs then there has been more cata loaded into the monory twan has been unloeded. Thus, there is date in the menory that has not yet been retrieved and witten to the tepe reconcen. If the tape recorier is not enerating an IVG, end if the nultiverter is rot loading the momory, end if there is non-coinctience ( $U$ and $U: 0$ on Card $B$ ), then unload memory and nte cheracter circuitry is activated (Card D). First a data point iden- 
tifien is mitten onto the tape. As illustrated in Figure a, the cata point identifion is cheracteristicelly identified on the tape by having deta bits $\mathrm{A}$ and $\mathrm{B}$ on. The identifier itself consists of three sequentially written hoxicocimal disits ( = 12 bits) for a total possible count, without repeating, of 4096. These three hexicecimal dicits are witten unden the control of a trires bit ID shirt resister (U16, U17 and U23 on Card D) which secuentially selects (Card I) the appropriate foun bits of a 12 bit counter distributed over cards $P$ and $G$. The initiation of data point ID writing occurs on Card I where non-coincidence (which nalres the CoTrC line lo\%) initiates the Feneration of a ByThsr pulse. This initializes the ID shift rezister (Cerd D) to select the first or the three hexicicimal digits. The Io shift register establishes and meintains the DIECT shift simal on Card D. This allows Genenation of SHTFT pulses (Card B) to carry the ID shift register through its tiree states. At the completion of risiting the data point icientifier tio events hapen. A four bit wite shift register (U18, U2h, Ue9 and Uth on Card $D$ ) is initiolized via the D shirt register $C$ line

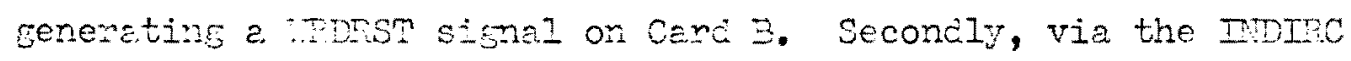
(indirect) Flip-jlop on Card $D$ an GIOAD nemory one-shot is tricsered on Care B. rhis causs the memory to be read at the Unload Admess (Card G) and the first byte of a chariel (sign pius 1st cigit) is passed to the mag tape formet reeister on Carc $\mathrm{F}$. The bit thet is . initialized into position $(\cdots)$ of the wite shift register selects the appropriate data bits out of the format reaister (bits 3-3) to form the first of zour ciata characters, which is then written to the 
tape on the rext ciock pulee. The IDJnC flip-flop is maintainod on by 1 so the seconci bute is unloaded from merom. When the unioed cycle has fetohed the secont and thind decimal ditit (CYco*P), the

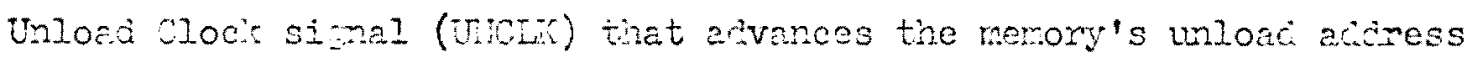
counter is also uses in confunotion itth the IDICC simal (Card E-

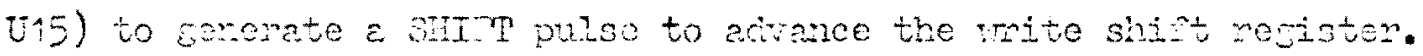
In position '?, the first dicit of the second cone nenory byto no: helc in the romet on rogisten on can Is imitter. since the third

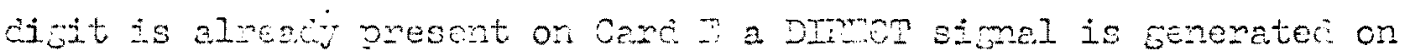
Cars D hich couscs a sint (Canc 3 ) to acvance the rrite shift resisten to 7. The third dist is nori selocted and rituen. i3 sets again the IDIS flip-rop, and a core cycle places the third menor: bite into the mas tape fomat registen. The CYCOP signal

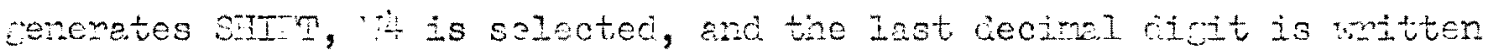
to tepe.

At this point theme are tro poseibilitics: either there are more chamels o: the same deta point to be witten, or the lest channel ô a cete point vas just rmitten. The resolution of these mutualy excluatre states is acomplishec on care a rith the genowetion or a

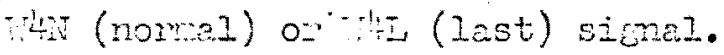

The

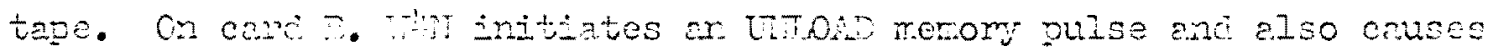

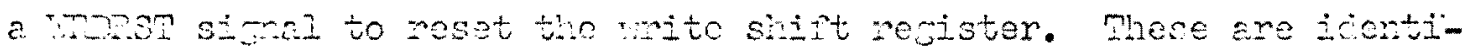
cally the eane evento that ocourad at the completion of miting the date point irentinion. Therefore the subsecuent process ciscussec above is ropected and four cigits of another chernel is iritten to the 
tape recorder.

Eventually the th signal will be present and if there is noncoincidence of memory load and unlaod adciresses, then the data point ID shift resister is resct by the BYTISST pulse ceveloped on Card B. The cata point ID is ritten and at its completion, the $C$ signal from the cata point ID shift resister initiates a memory U.WOH via

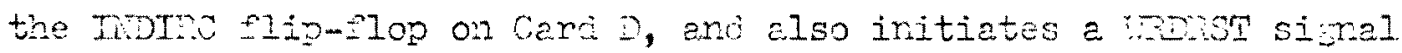
on Card 3. This is icenticai to the state initially discussed and also that cronted of w above (except that the three characters of a ciata point Io have been mitten). The logic then cycles through the three bytes of each charnel's converstion in whin's are encountered

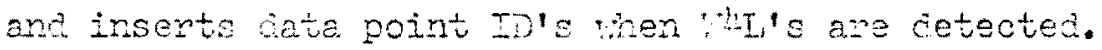

The data triting process continues until coincicenee is reached on Carci 3 . The COIfC sienel blocks further generation of the BYRST pulsc. Thus the thmes cat? point In cheracters are not vaitten, more importanty an UnOOD signal to the menony is not generated by data point ID completion, nor coes the WDEST simal initialize the urite shift recisten. Date transfer has stopped! on Card E a circuit cetects that neither data point ID cijits nor data cigits are beins selcctec. This fores the mag tape fomatier into a filler di fit state, in hich binkry 12 's are mitten to the tape.

To Gain a more cetailed uncierstenting of the SADDAB circuitry, it is eugested that the Elook Diamom be thoroughy uncerstood pirst. Then cetails of sirouit opmetion can be relatively easily cleened from the soincmeties and the circuit functions brietly cescribed in the next section. Liberal use of the Miring ista and the Signal Cross neferenos in the apnondices might malke the task somewhet easier. 


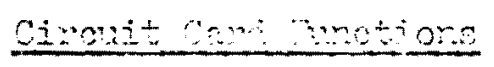

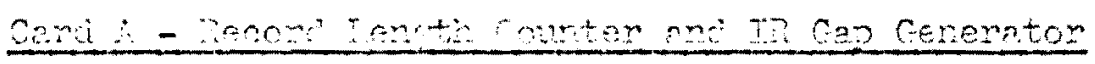

Four basio furctions ane perfomed:

1) We marrctic tape characters aritten are countec so that IO's (inton-neconc nass) may be inserted at the enci of erch data viocis.

2) Ing timing is conerated.

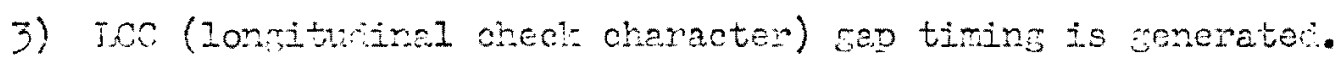

4) The numoen on tapo recons mitten is counted fon dienlay on the consuolzon ront perel.

The recond Ionth courtem consists of trelve bits and thus ina a matimum count of loge. Four sutches on the back of the contioller front penel sets the value to hich the counter is initialized by

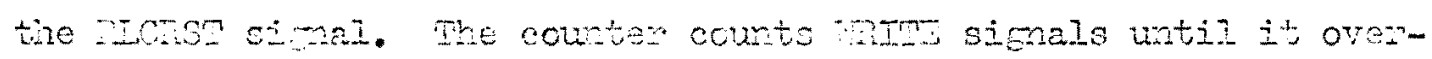
flors. The MTIO signal tuiggers a one-shot that sets the counter back to its initial rive. It also tricsers the IR Gao Gerenator anci the ICC Gap Ceneraton.

The In Gap Generator is a simle onc-shot uth RC timing. There are to ne wich are either open on comected to +3.6 volts in a mutulit enclustre arsicn. If the PRST line supplies current through the 1. sesiston, the ore-shot timing is 31 milliscoonss. If the 30 resistor is used, the timits is 100 milliseconds. The IrGap siona?

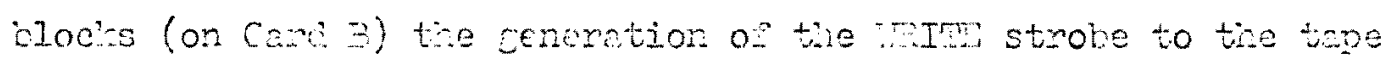
recores.

The ICO Cap Ceneratow is a onc-shot that operates identicelly to the In Ges Gensaton. The $330 / 1000$ pecond timing cetermines the 
the position o: the loncitucinal check character trailing the cata characters (approximateit 5 characters later). The LCCSLI signal resets (via cand s) the wrte-current fip-lops in the tape recorcor, the action ricis actually arrios the ico.

The Recond rumber counter is a simple couter mich is initially set to zero at Sing time the thon signel. It simply countu

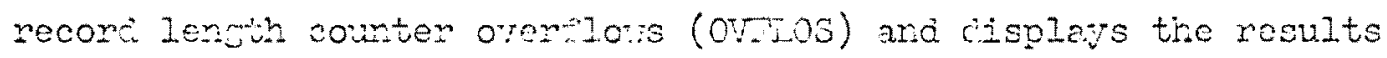
vis livits on tive controllen's front panel.

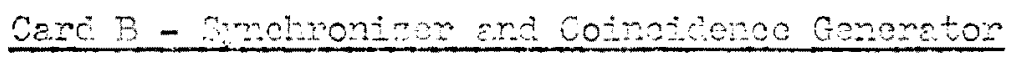

Four basic rumotions ane perionned:

1) Synchronization of menory wlocing and the uriting of cata point icentiriess and the data cheriel dicito.

2) Control of the acronoement and output sating of the load and unlooc memory abiress counters.

3) Genenation of the …ITE strobe.

4) Genention of a mom adwess coincicience signal. Synchronization of wenom unioatine and chanacter miting is discussec in the General concepts section abore.

Hemory ochess counter acvenoement oocuns lith the completion of a momom cyole (Cronp). The cownter hich is adraned is cetemined

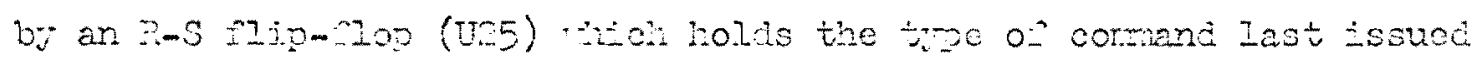
to the momo:" We output soting of the menomy adiress courtems is establishod wy ruventer activity. The MJAs signal (Cand I) seta

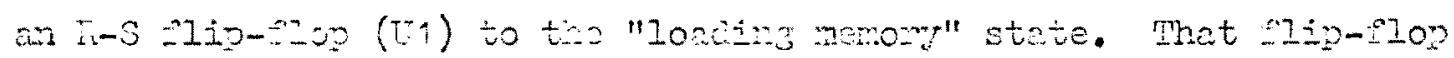
stays there watil the vultiverter is finished at wich time U1 is 
reset by the 10 t $10 \mathrm{O}$ G sirnal that is reestablished on Card D by the INSTic simal.

The iriti strobe is generated by a one-shot (U11) criven by the Clow and eater (USA) ay a olocked dextrative (U:7 and U18) of the IPG:P signal.

The Dotnotdones Generetom compres the state of comespondins flip-rops in the momory lodi and unloac achress counters. If ary of the nine =lip-fops do not aree the nerom aciresses are ditferent and the coincience is not achieved (Cortc remains $20 \%$ ).

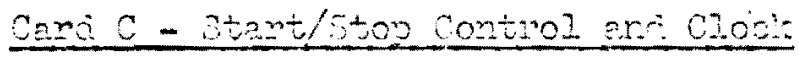

Four basto Hunctions ane penomsa:

1) Initializins all. counters, format shift reeisters and error Ilip-ropo.

2) Controi or mecorcen tape motion.

3) Gating semplins comancis.

4) Genemation of a precision clock signal.

Rescttins of many counters and emon alip-rlops can se asconpliched manuly (sons), The convert fip-flop (US), set and reset respectively dise BTAR end Snop pushouttono, also automatically resets all the counters and error Hip-inops. In adition the convert

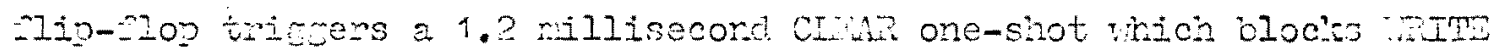

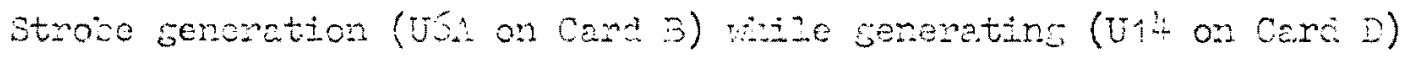
pseuso-sinte aimels to elean out the lowmet shift reatsters on Card D.

A Fomanc ilip-flop (up) controls tape rotion. It is sct by 
the clear one-shot and reset wen the last ISO is rritien. Tre Deta

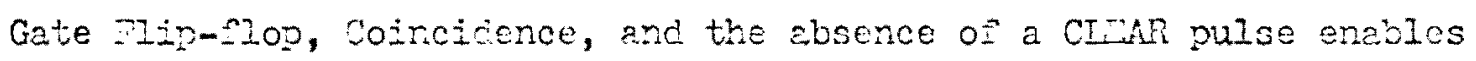
this rinal activity of a sams conversion sequence. Bamlino comands are olloved (Ut?) to pass to the iultiventer at the end of the initial InG intitited py pushing SnIT. Pushing

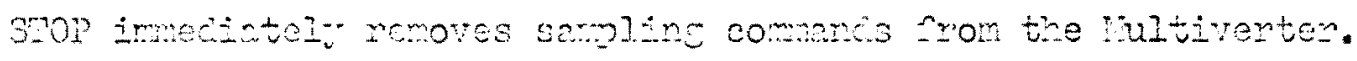

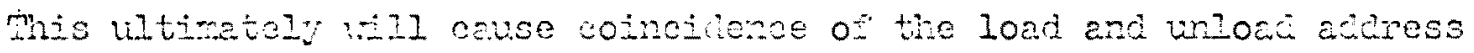
countere, end thus ereble tic bate (U6) which will allor the last Ifo to stop the tepe transpont. The system's mestor ciock $(2,03)$ is a precision themeily comensated free munirs multiviorator with a period of 60 microsecons. It iriasers a one-shot $(0 \cdot 3)$ winch has a selectable duration on 33 or 145 microseconcis. In the $2 \mathrm{AST}$ mode, each cycle oi the riduiribnetor fincs the ore-3hot and thus the 60 microsecond penion is maintained. In the SIOt mode every second and third multivibrator period has no pesect because the one-shot is alraay firec. Thus there is effected a 3 times division of the rate siving a period of 180 mienoseconts wich is recuined fon mitins 556 opt vepo at 10 IPS. The mester clock pulses are shaped by a 30 microsecond one-shot

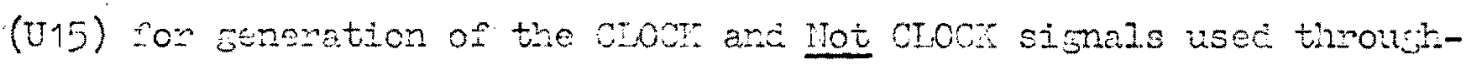
out the contiollen.

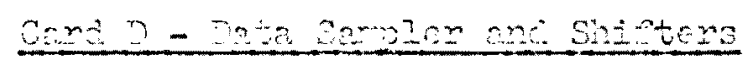

Five bsic functions ano performed:

1) Cycling of the sultiventer.

2) Golins of remor loadin. 
3) Data fomattine of the isultivorter output.

4) Data formatting of the data point icentifier counter outout.

5) Data formettins of the core memory output.

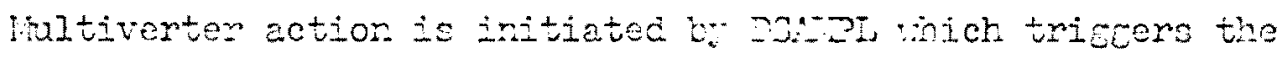
INSTrip one-3hot to saple and convert the first charmel. Subsecuent chamels are semplce by feesed from the miltiverter (INSUSY) triceorine a one-shot Wich is sated by the Wustro signal. Samoling and conversion of the muber of channels selected on the rultiverter Front parel propeeds cutomstically until the IVGric signal indicatas that the first chernaz is ajair selocted.

Cycling of the momory loeding is intitated by r.trus, continued through the sccond and tilire oyele by the Crcorp simal, ard is finaliy teminated by a cate (US3) Wich allow the ovcops simal to pass

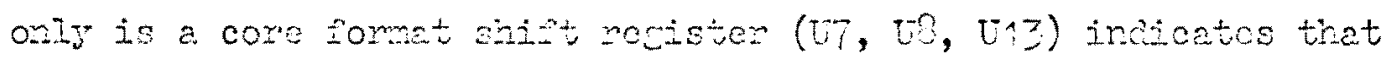
there is data to be witten.

Data formetting of the hultiverten output is accomlished by this seme shift registen. Intialized to select the first core byte

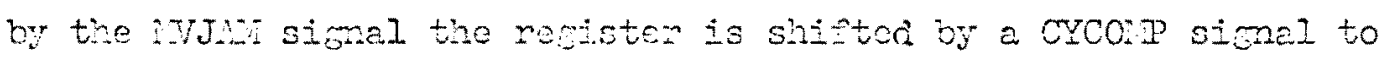
select the scound anc thire brites.

Data formatudas of the deta point iclentifier is accomplished by U16, U17, ane U23. Initialized by SWOST the rosisten selects the

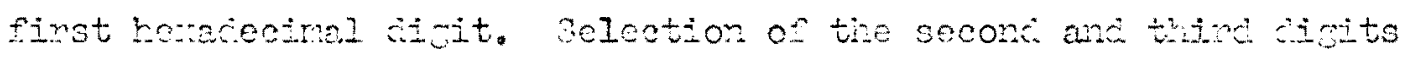

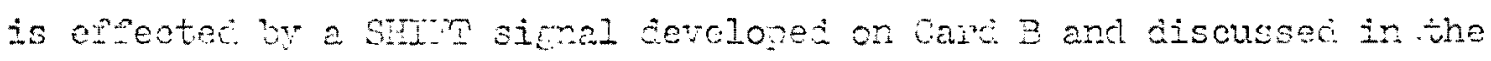
ceneral Concops soction biove.

Data fomatuine of the core memom outut is accorpiched by $v$, U2\%, U?, and UI!. Operation of this circuit is similan to that of 
the clata point fientifier sinte register.

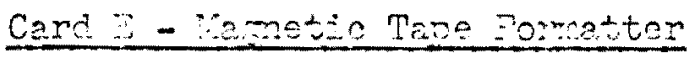

Five basic functions aro periomed:

1) Holding of the core mamom output.

2) Deteztion of tire last chamel plas ( $h_{L}$ ).

j) Gatins of the conventad data as cecimal dicits.

4) Geting of the deta noint fichtifien as hexidecimel dictis.

5) Gereration of a pinfer cigit in the absence of any data to be imitten.

All of these functions are cone in a straichtoriard namer and can be nost easily uncenstood by direct reference to the schematic. The geting functions are ccoomlished by the mitually exclusive

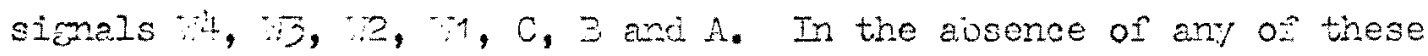
signels, the character output is celalted to a binary 12 stete by the transistors of and 2 anci associated dioces. Furing loading of the merory rom intiverter outnut, the character outout is forced to a binary 12 by the simal Fono developed on Card 3 .

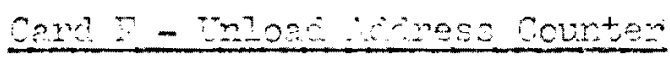

Three beste iunctions are periomed:

1) Pantial gensection of the cata point identivier.

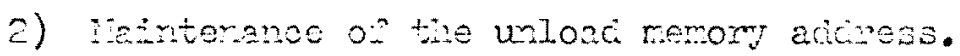

3) Geting on tre unlori sciness to the core memory intertece.

The lest ain on the trelve bits of the buta point ichontinier are

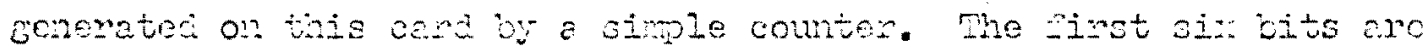
cenerateci on Card G - Loaci Aderess Counter, winich is an icientical cord. 
icidress mintonence is pextomed by a simple nine bit counter. Dach UILOAD command generates on Card D generates an UNCLis signal wich is the cloc: input to the counter.

Wen the unloac ackess is recuired the iound line coes $10 \%$ and thus allo:s gatine of the counter outout to the memony adiress cincuits.

\section{Carc G-Iose nowess counter}

The operation oi this cord is icentical to that of Carc I - Unload ficiress Cownter.

\section{Card I - Yemory Interáce}

Tho basic sunctions are perfomed:

1) Vemory adiress generation by oa'ing the gated outputs of the load adiness countor and unloaz adciness counter.

2) Intenacing (ouforing) memom control, nerony inout and merory output sierals.

The "boyy" connections on the schenatic represents the remory cable which is hard vired to this card. The "arroved" connections are those of the cari's edge connector. The circuitry is straichtformarci and can be rearily undenstood from the schematio.

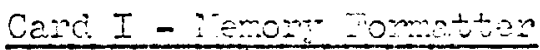

Three basic functions ame perionmed:

1) Holeing of the iultiventer outout.

2) Gating or the ivltiverter output as bytes for the momory.

3) Generation of tire last chemel sas.

The rinst tio functions are straightionrard and can be reaclily 
understood from the schematic. The MVYIC sicnal incicates that the lifliverten is looking at the finst analoo chamol. Therefore, the last aralos channel is currently in the holding resister. Thus, when the thind kyte (oz) is witten the last chemel flag (a bit in com-

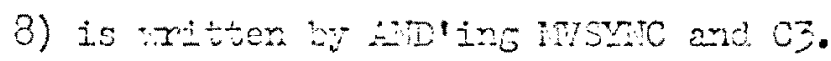

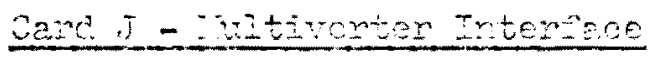

One besto guretion is perfomed:

i) Irtentacing (burfering) mutiventen input, output, and control signals.

The circuitn is straichtomard. Details of the timing may be fourd in reserence to

\section{Cardi- Istrt mivers}

One funetion is panorrad:

1) Suppling zaw curront to the contiollen's front panel incicator lisits.

Ret lojic locs rot heve surficient curment capability to dxive indicator Iichts. Thereione, trencistous must be usec as lero cravans.

\section{Caxd 2 - proon ens status}

Three basto hutetions are periomed:

1) Tape trancport erron cotection.

2) Controngen anchnonization anror cetection.

3) Supling lom current to incicator lights.

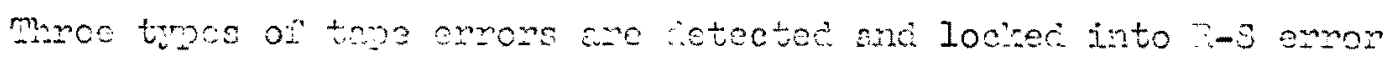
flip-gloss. Transport errors (EOT, Tor, Broken tape), paity errors, 
and echo cheoit exrors are a.1 detcoted on Card $S$ and pass respectively

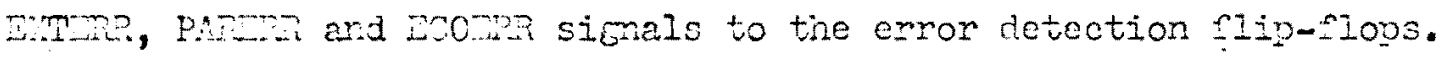
Synchoriation errow checling is performed by U3, Ut and $U 7$. Vagnetic tapo chamacter 1 ( $(\because)$ is tested asainst cone byte $1 \mathrm{by}$ checing that brte positions : and $2(131$ and Na2) are zerose. Tape chanacten $(\cdots)$ is tested aganst cone cyte 3 by checing that jyto positions 5 and 6 (II5) anc iJu) are zerocs. Iagnetic tape cheracters 2 and $\exists(2$ an: 3$)$ ane tested (U) ajanst the probable presence of byte 2. The outputs o: these tests are strobei by the rrito onoshot sipnal M3. If an inconsistency is detecied, the sync error flip-lop to is sot.

This card also provices the interface transistors to the crron and status incicator 1-itus.

\section{Card 3 - Tepe Reconden Intenface}

Tho basic functions are periomed:

1) Intersacing to the -10 volt negative logic of the remedy tape reconcien.

2) Comporison of the charater sent to the recorcer tith the echo check recelved from the recorcer.

The -10 volt nerative logic used in the Rennedy DSE70: tepe reconcon recuirse transiston level convorters to interrace inth the ETL lozic usee throunout Bnots. Fon the sake of conpleteness, all tope recorien lines vere intemaces even thoung some of thom rere not used. Deteils of the moning of all simels my be found in neverence 2. 
Cormarison of the character sent to the recorder with the echo received from the resorien by the cheracter actually uritten is accomplished by frolustvi-08 circuits (U3, Uh, U5, U6, U7, U10, U11) operatire into a seven-irput 0 : cincuit (U2 and UD). If there is a mismatch, an acon signal is eneratec. 
RESULTS

Succinctly stated, the results are that SADDAS works. Over 4000 eight crcle trials (each with seven channels) have been digitized, yeilding therefore over 220,000 cycles of digitized data (4000 8 x 7). Each cycle has approximately 150 samples in it, so there has been in excess of 33 million data points digitized $(150 \times 220,000=$ 33,000,000). With four characters per data point, over one-eighth billion digits have been digitized and written to magnetic tape.

Figure 4 is a reduced computer listing of typical SADDAS output data point identification followed by seven channels of digitized data. The input to all seven channels was a poorly regulated 5 volt power supply that had noise and sixty cycle hum on it, which explains the existence of all positive values of $5000 \pm 50$ millivolts.

The performance of the system is sufficient to meet the initial design goals. In converting seven channel IRIG (Inter Range Instrumentation Group) magnetic tapes sampling rates in excess of 360 samples per second may be used. This allows three cycle biological data to be sampled at a rate sufficient for $3^{\circ}$ phase resolution, as was the initial design goal. When sampling fewer than seven channels, the sampling rate may be progressively increased: e.g., SADDAS will convert one channel at a rate in excess of 2000 samples per second. 


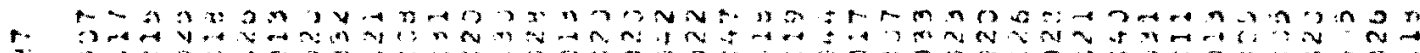
\begin{tabular}{lll}
\hline \\
$H$
\end{tabular}

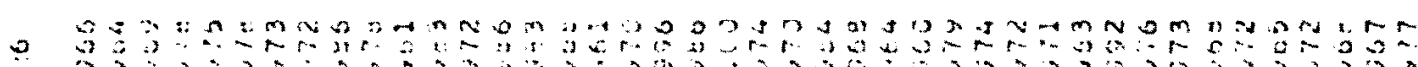
u

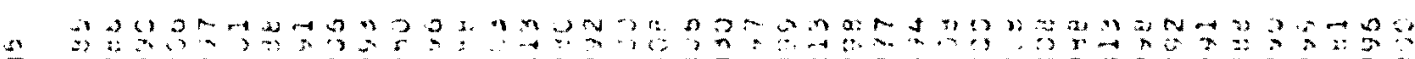

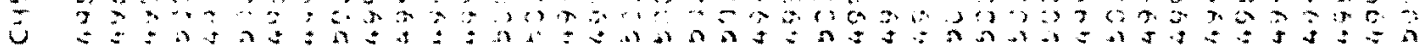

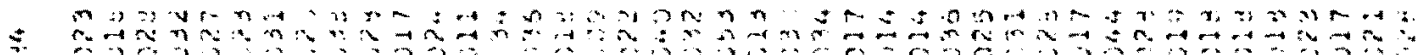
U tha

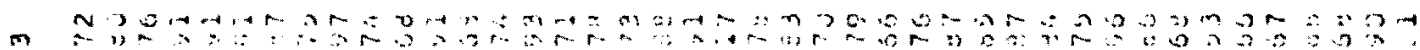

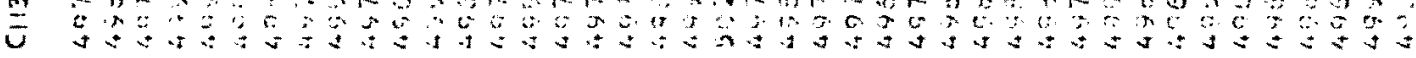
N

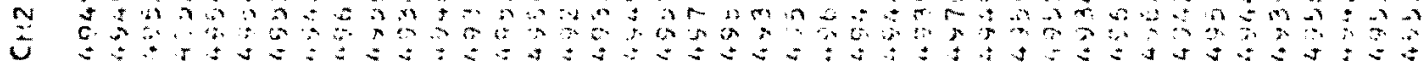

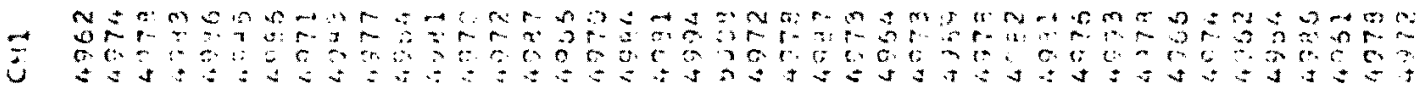

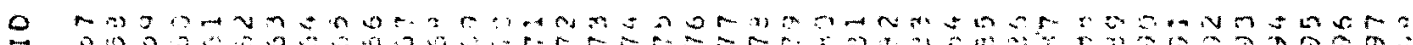

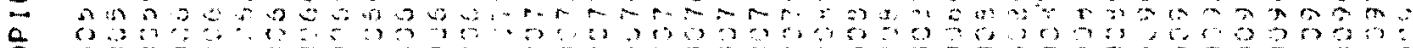

各

ค

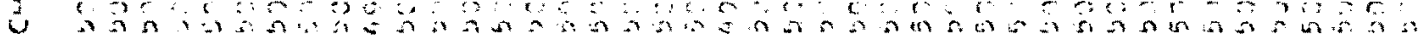

-

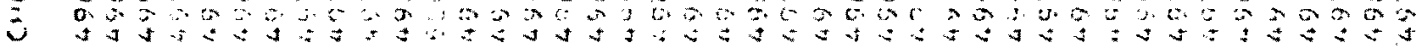

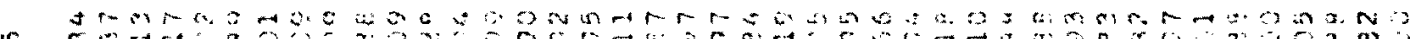

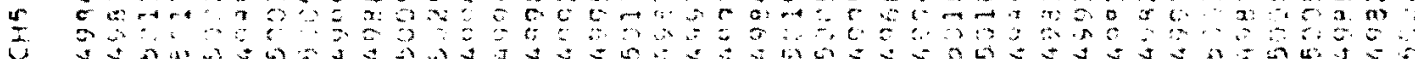

\$

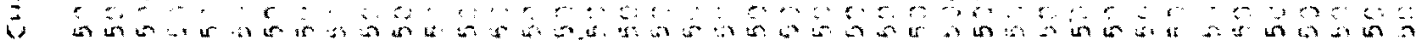
F.

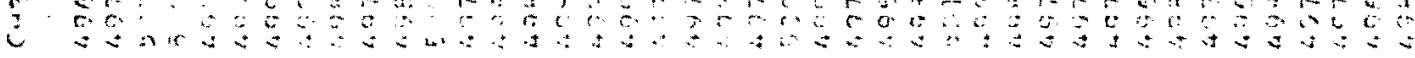

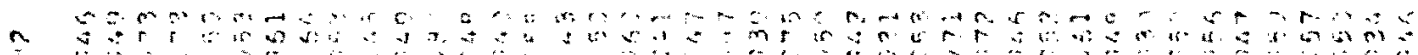
Z,

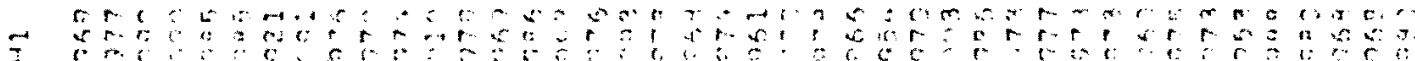

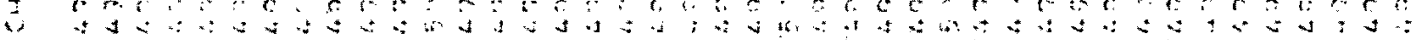

0
0 Dimes. 1. 


\section{REFERENCES}

1. Ferroxcube Corporation of America. Core Memory System Series FX-12. Saugerties, New York. 1966. 47 pgs.

2. Kennedy Company. Model DS370R Incremental Magnetic Recorder. Altadena, California. 1966. 65 pgs.

3. Power Designs, Inc. Instruction Manual UPM- 6 Power Supply. Westbury, New York. 1966. 14 pgs.

4. Raytheon Computer. Technical Manual A/D 20-17BCD Multiverter. Santa Ana, California. 1965. 217 pgs.

5. Teletype Corporation. Technical Manual - 32 and 33 Teletypewriter sets. Skokie, Illinois. 1965. 383 pgs.

6. Petersen, Walter A. "A Flexible Data Acquisition and Formatting System for Input to Digital Computers." Section 2-C-2, IEEE Region Six Conference. Institute of Electrical and Electronic Engineers. New York, New York. 1968. 7 pgs. 
APPUITIX I

SCHEMTICS

BIOCI DIAGDA

SCEMTRTC NOTHS

CADD A - Fecord Length Counter and Th Gap Generator

CAND B - Smchronizer and Coincidence Generator

CABD C - Stant/stop Control anci Cloc:-

CARD D - Late Sampler and Shifters

CABD E - Magnetic Tape Pormatter

CAPD P - Unioad Address Counter

CAID G - Ioan Address Counter

CAPD $\mathrm{H}$ - Nerory Interface

GADD I - TEnom Eomatien

CARD J - iultiverter Interface

CABD Ir - IiGS' Drivers

CAUD N - Exror and Status

CARD S - Tepe Tecord Interiace

IP - Wront PeneI Ijights and Britches

BUTER 1LAOY

POTRR SUPPITS ND PACH POWTE CABLIIU

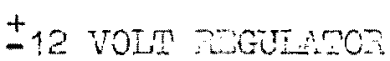

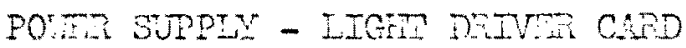

RAD CAOS BATPCH - DAR - TMY - 1130

PULSE GEHEUTOE CADD 


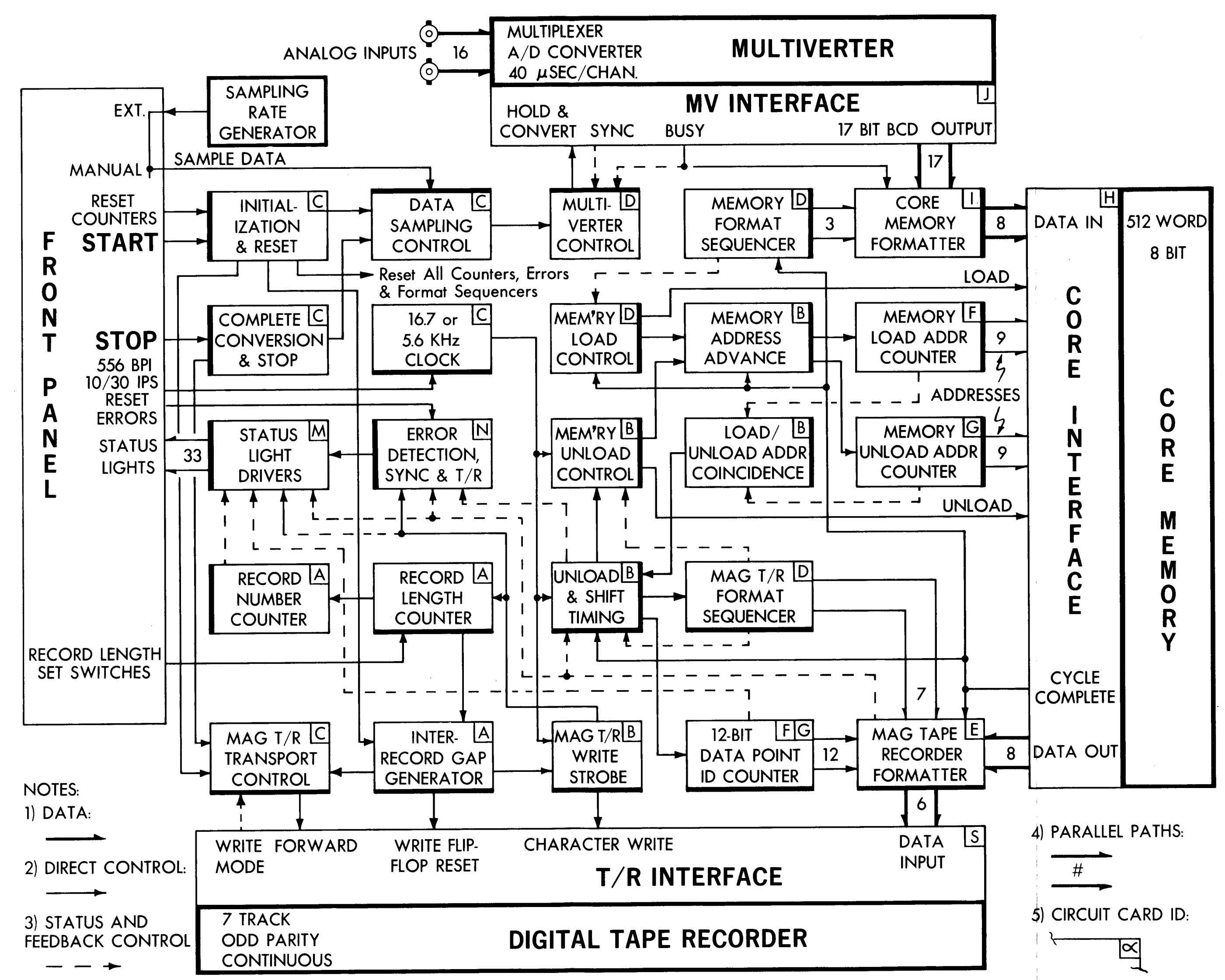




\section{SCHEMATIC NOTES}

UNLESS OTHERWISE NOTED:

1. All NPN transistors: - 5 are type 2 N4275

2. ALL PNP tRANSISTORS: - 0 ARE TYPE 2 N3906

3. ALL GERMANIUM DIODES: $\triangle$ ARE TYPE'TEK' 6075

4. ALL SILICON DIODES: $\rightarrow$ ARE TYPE CD 6538

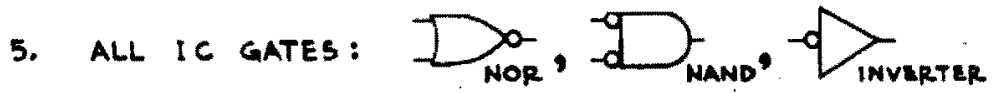

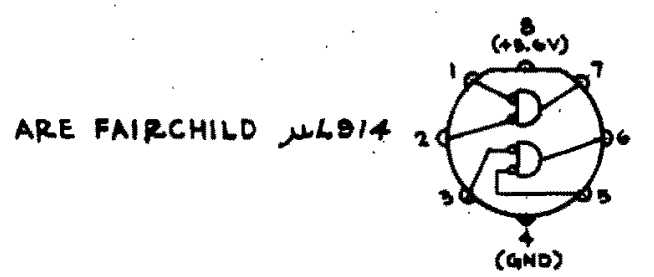

6. ALL BUFFER AMPLIFIERS:

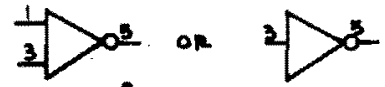

ARE FAIRCHILD $\mu L S O 0$

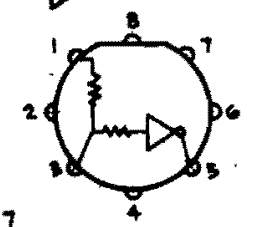

7. ALL JK FLIP-FLOPS:

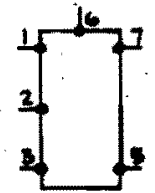

ARE FAIRCHILD $\mu L 923$

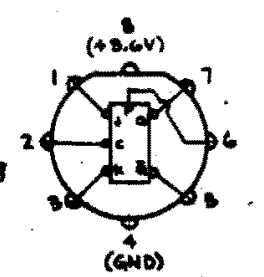

8. ALL EXCLUSIVE OR's:

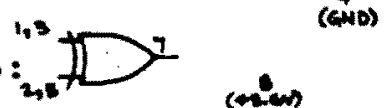

ARE FAIRCHILD $\mu 2908$

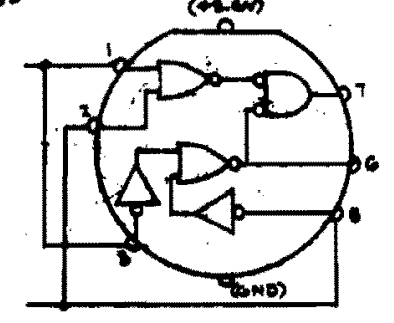




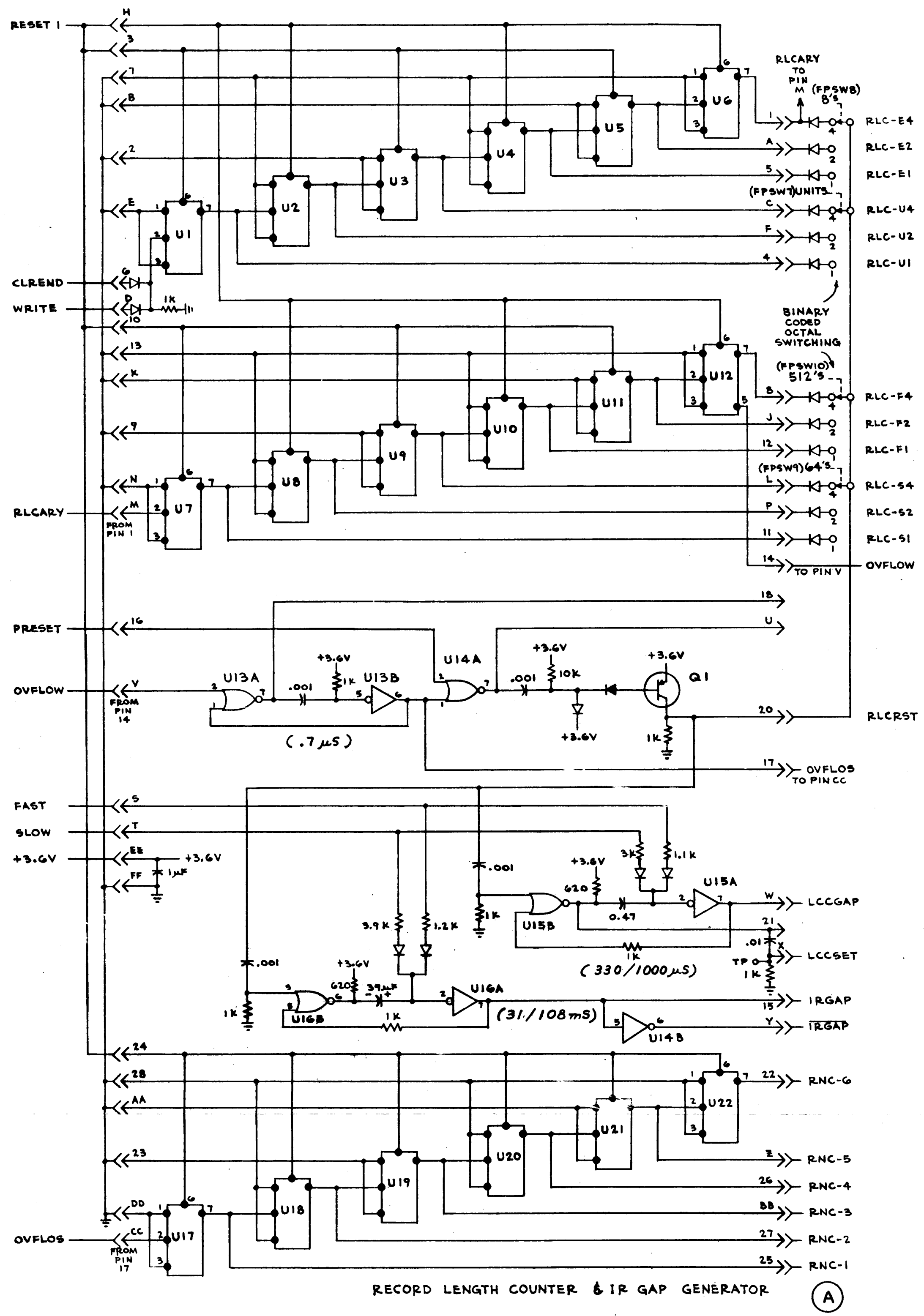




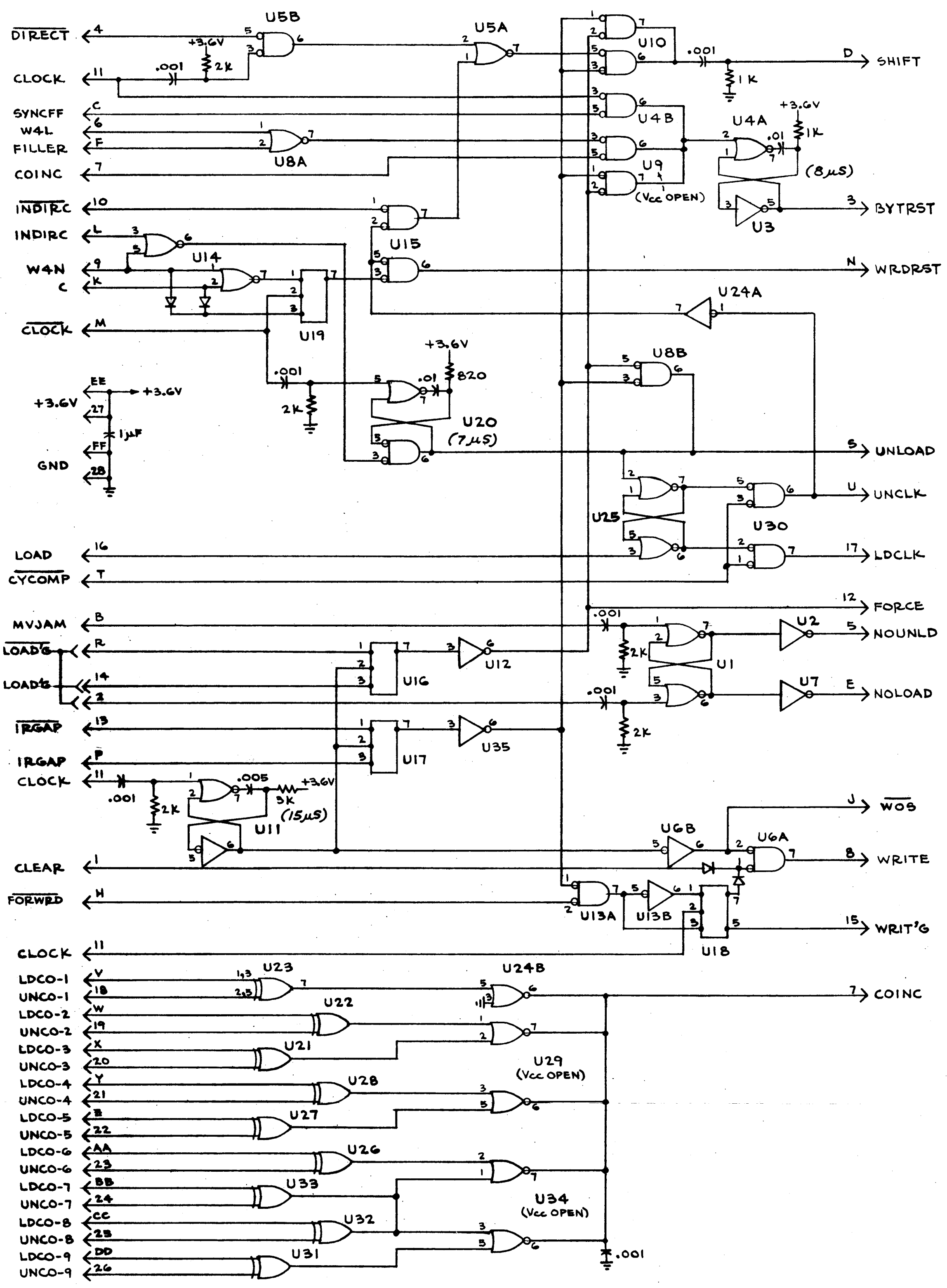



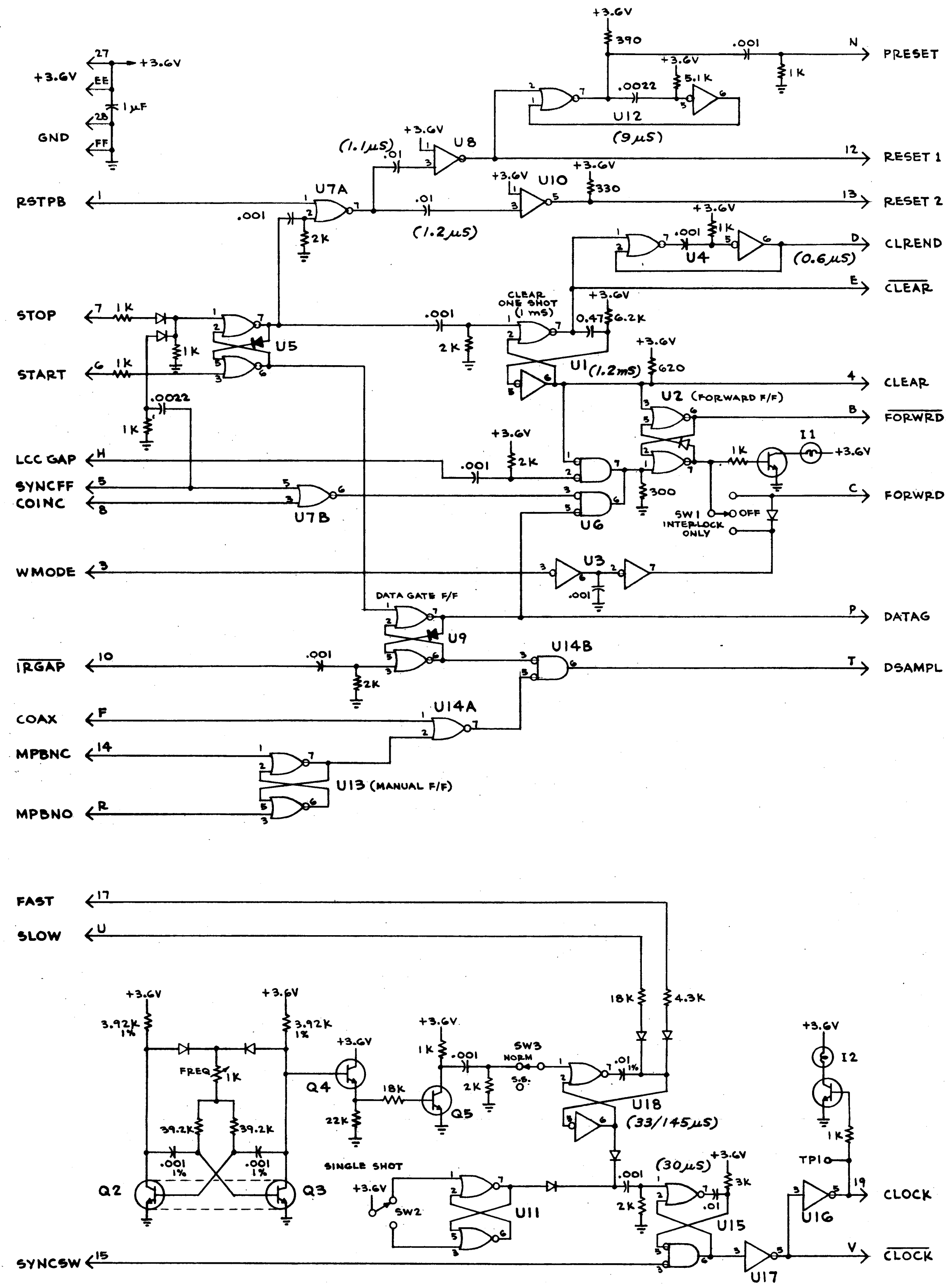

START/STOP CONTROL \& CLOCK 


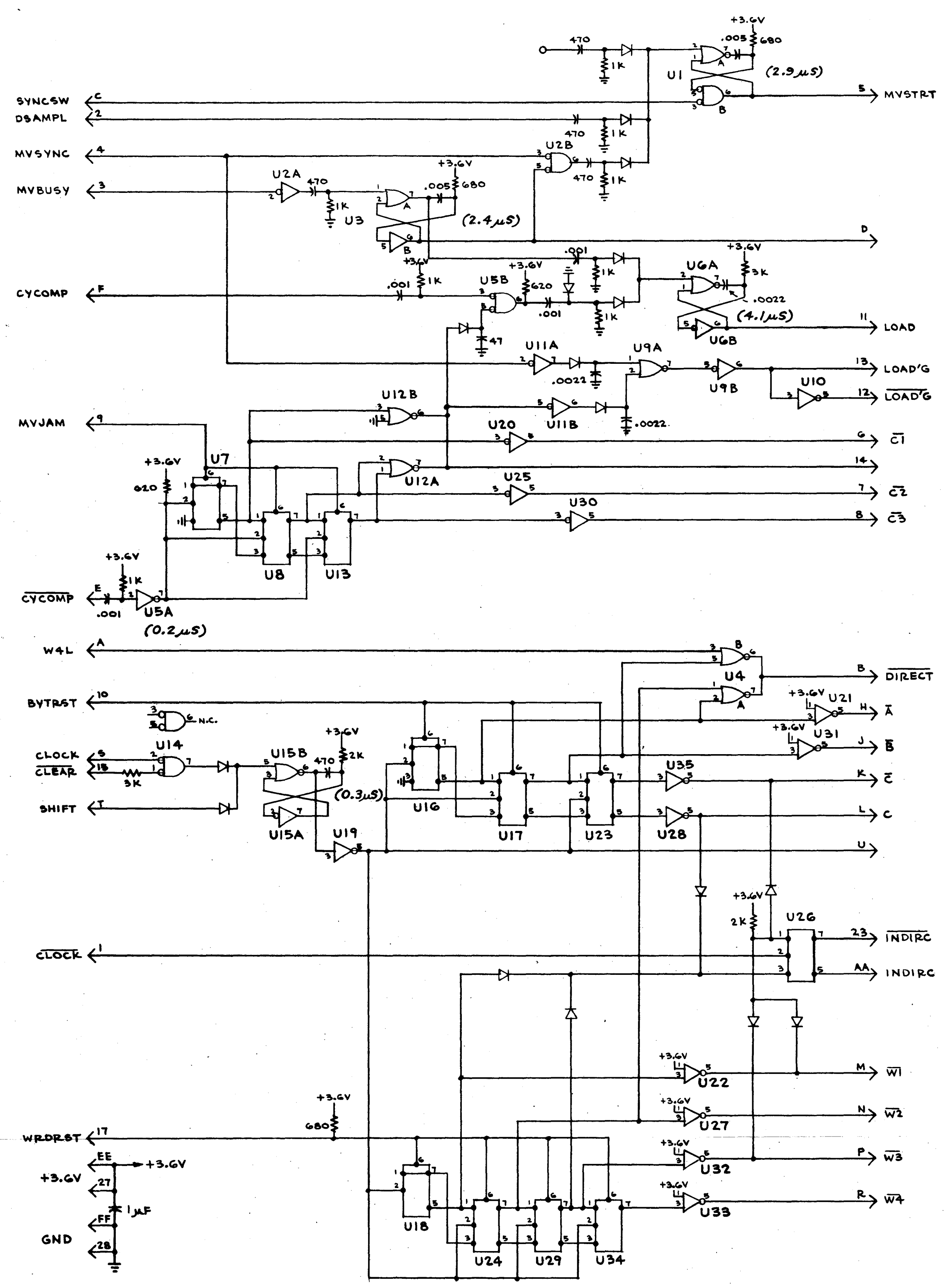

DATA SAMPLER \& SHIFTERS 


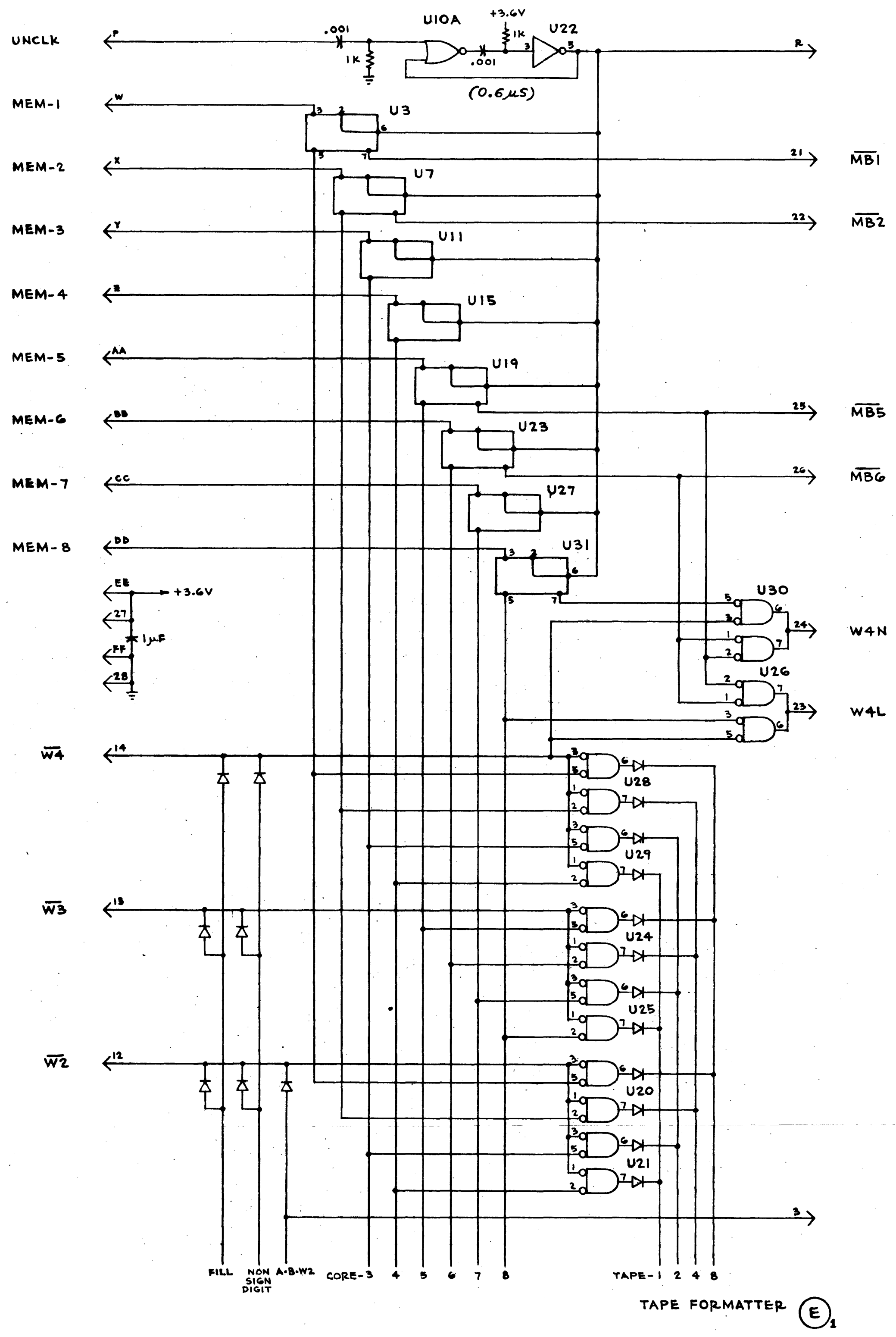




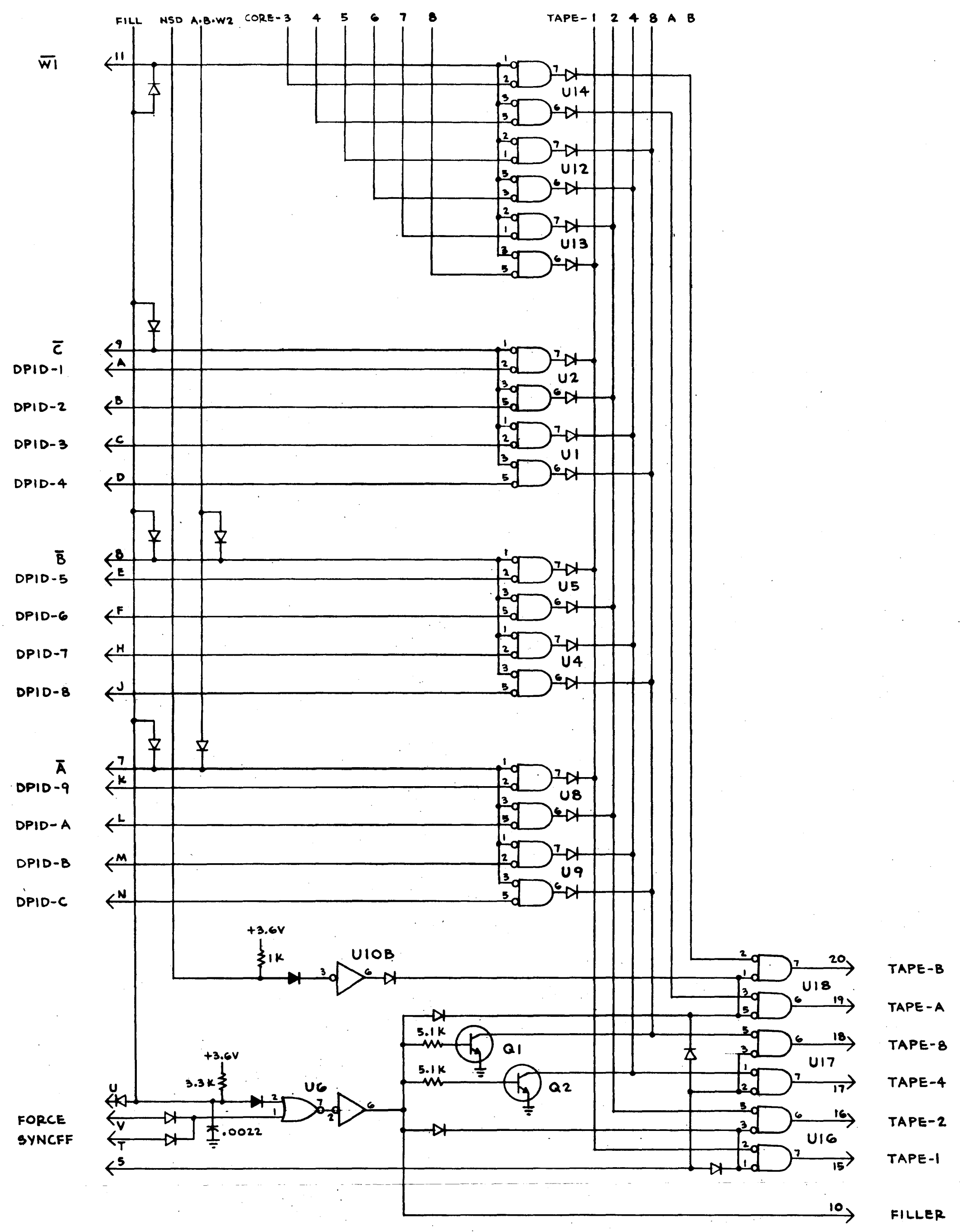

TAPE FORMATTER E 2 


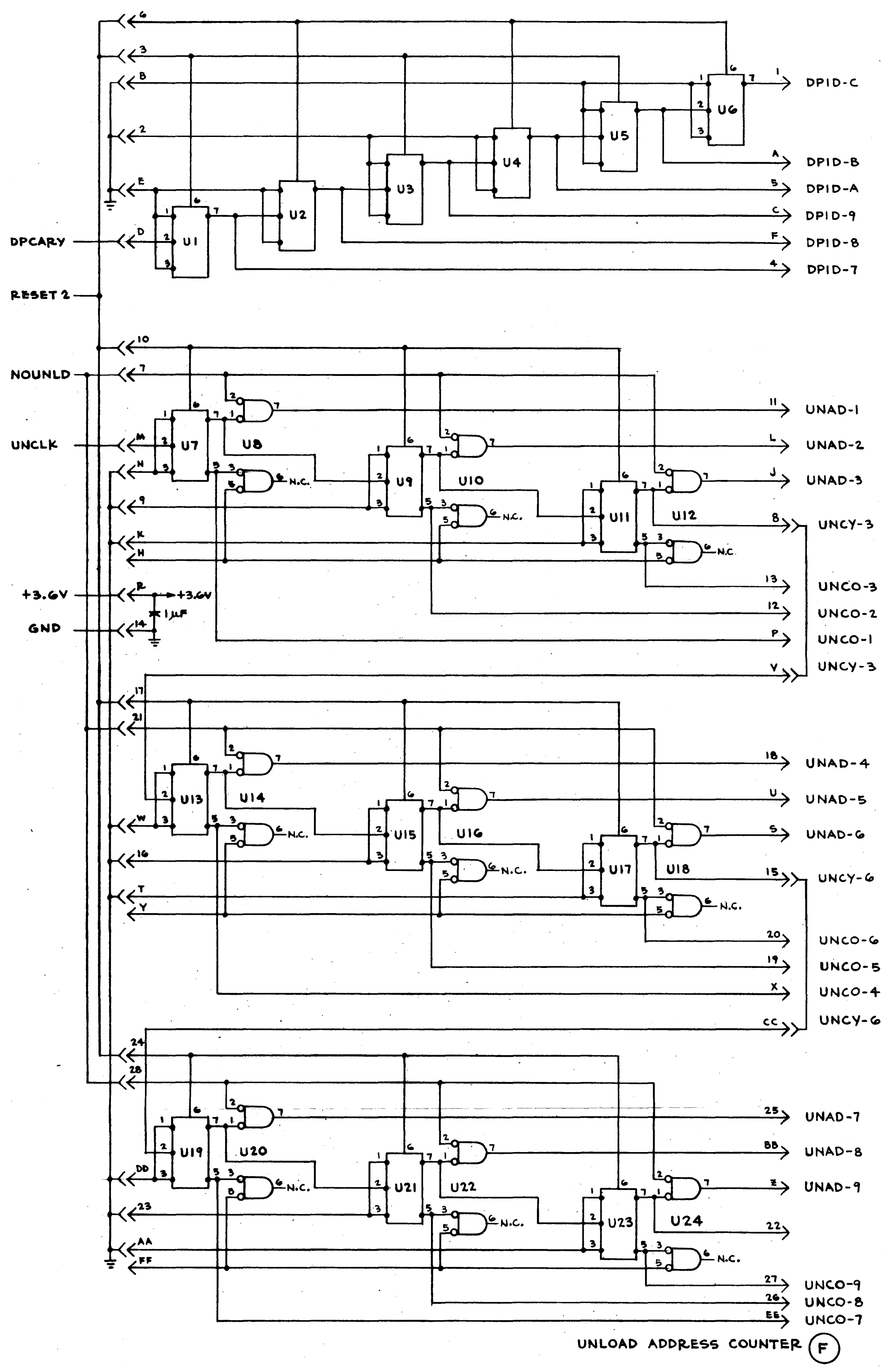




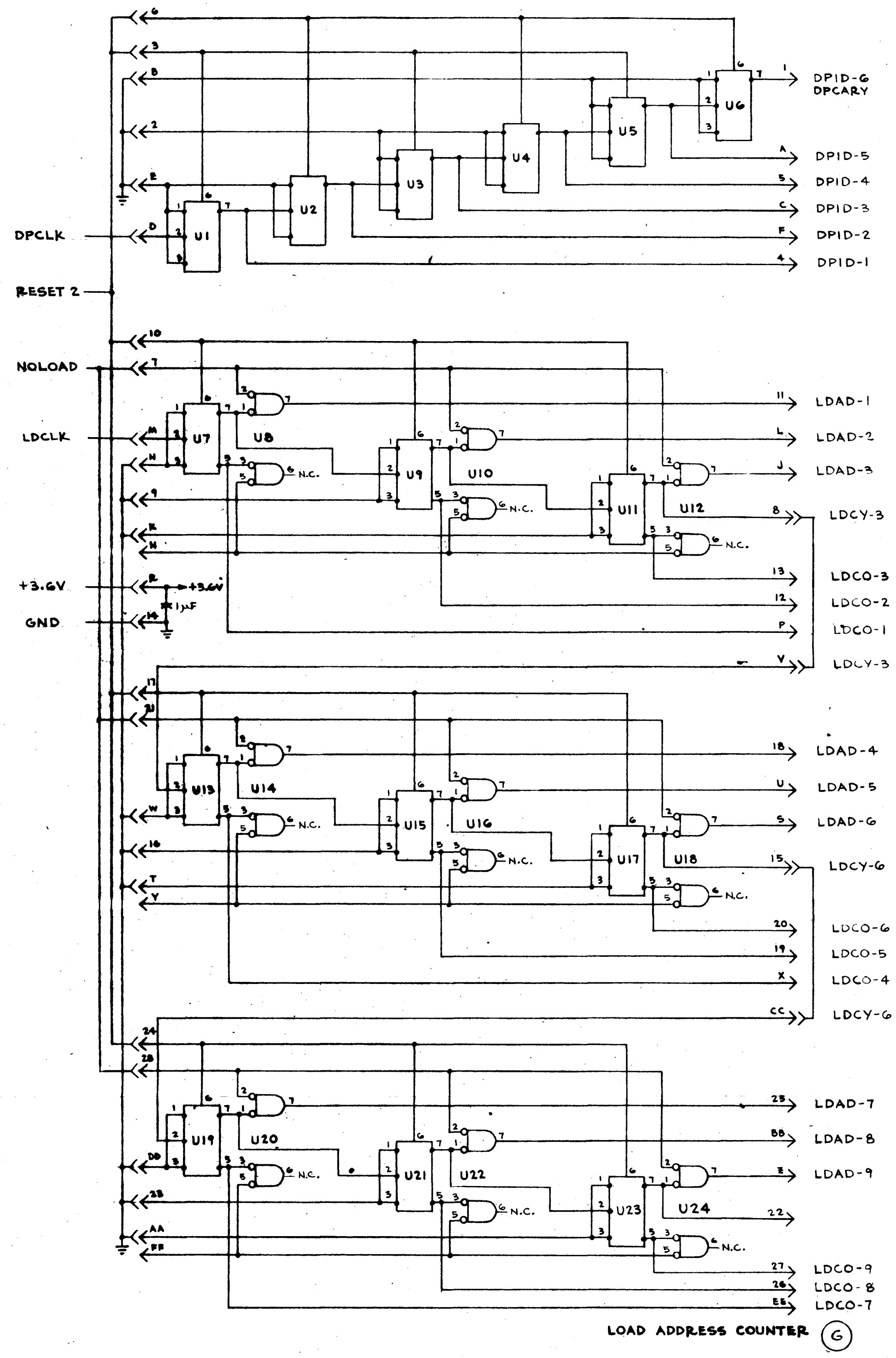




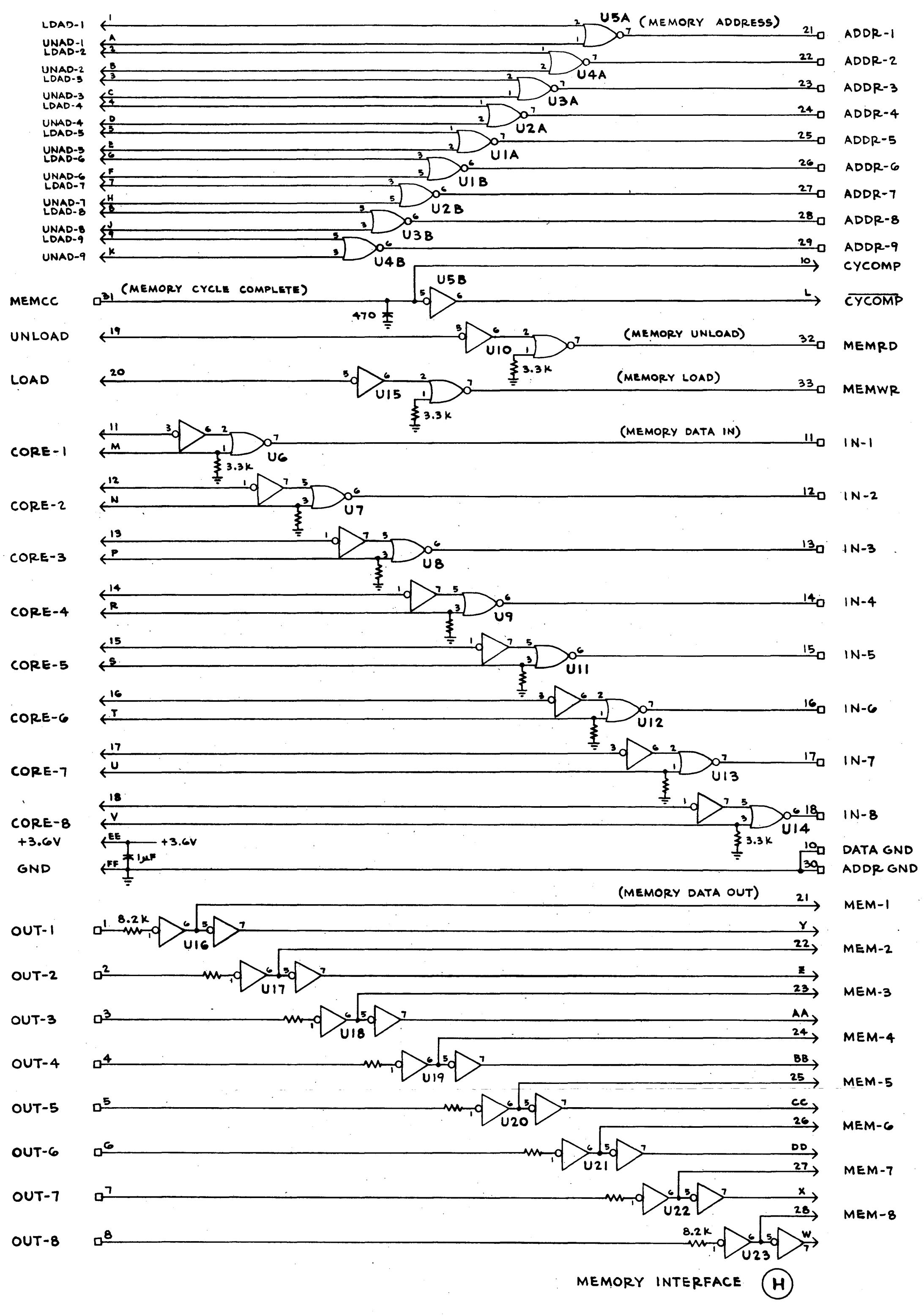




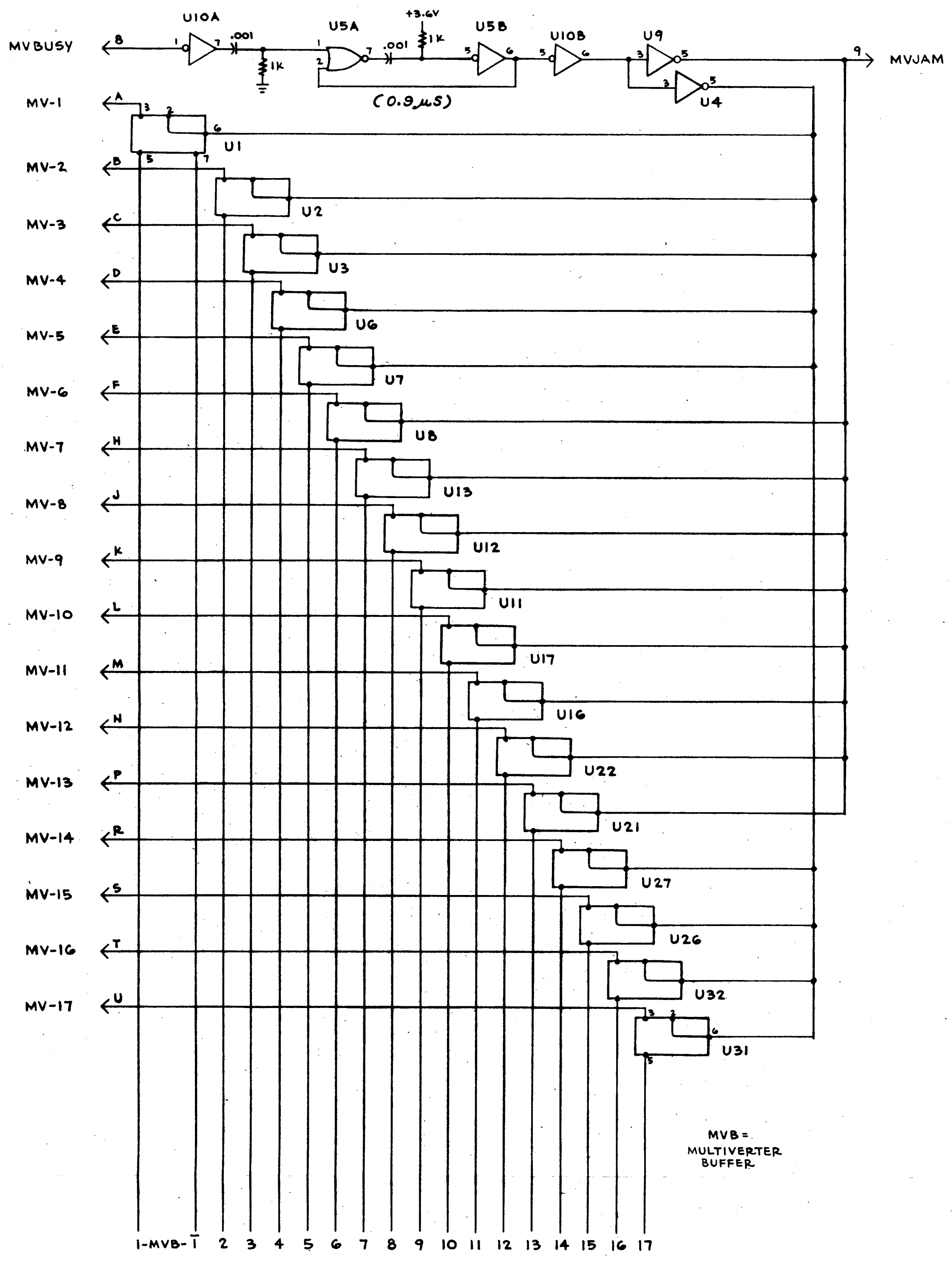

MEMORY FORMATTER (I), 


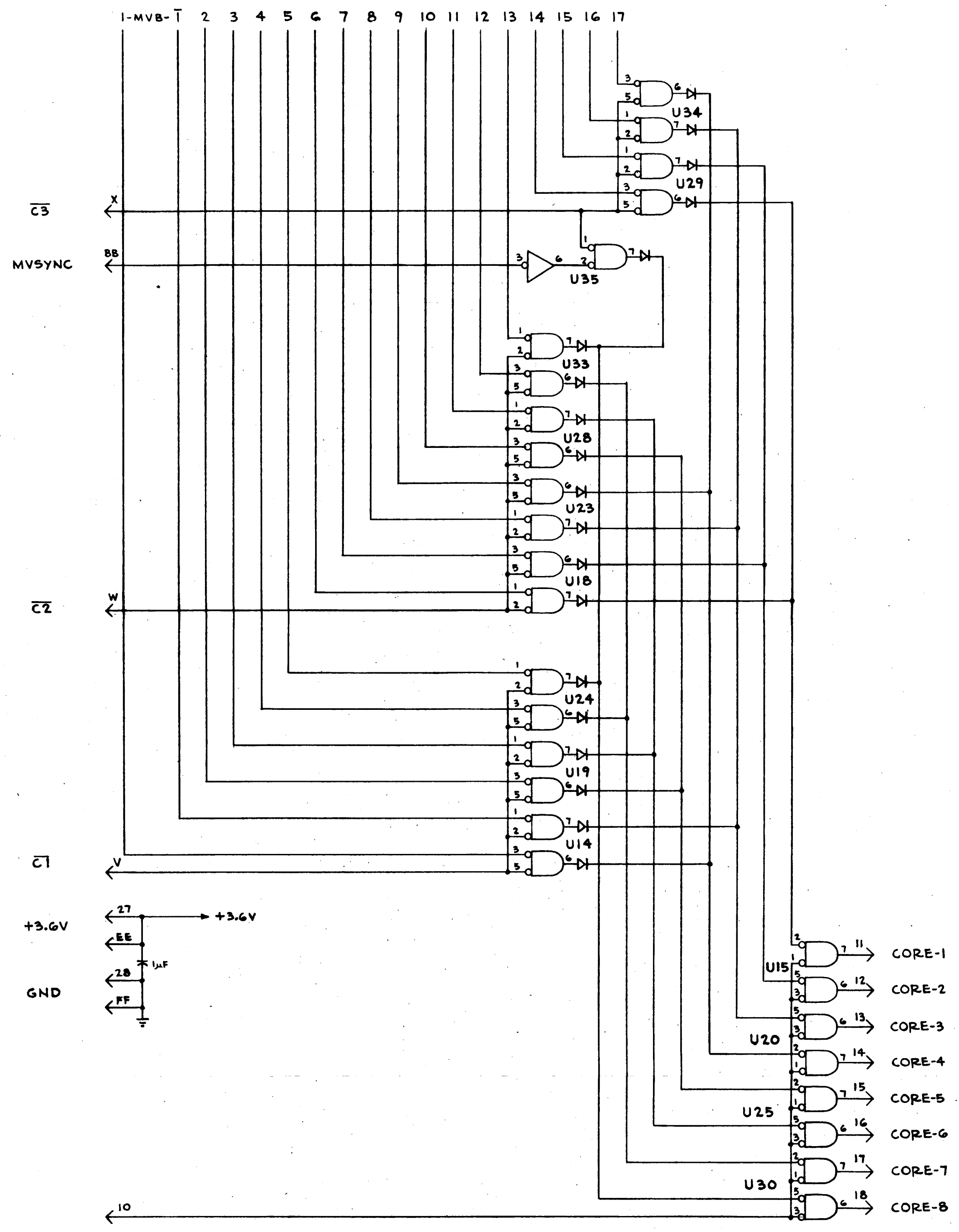

MEMORY FORMATTER I $_{2}$ 


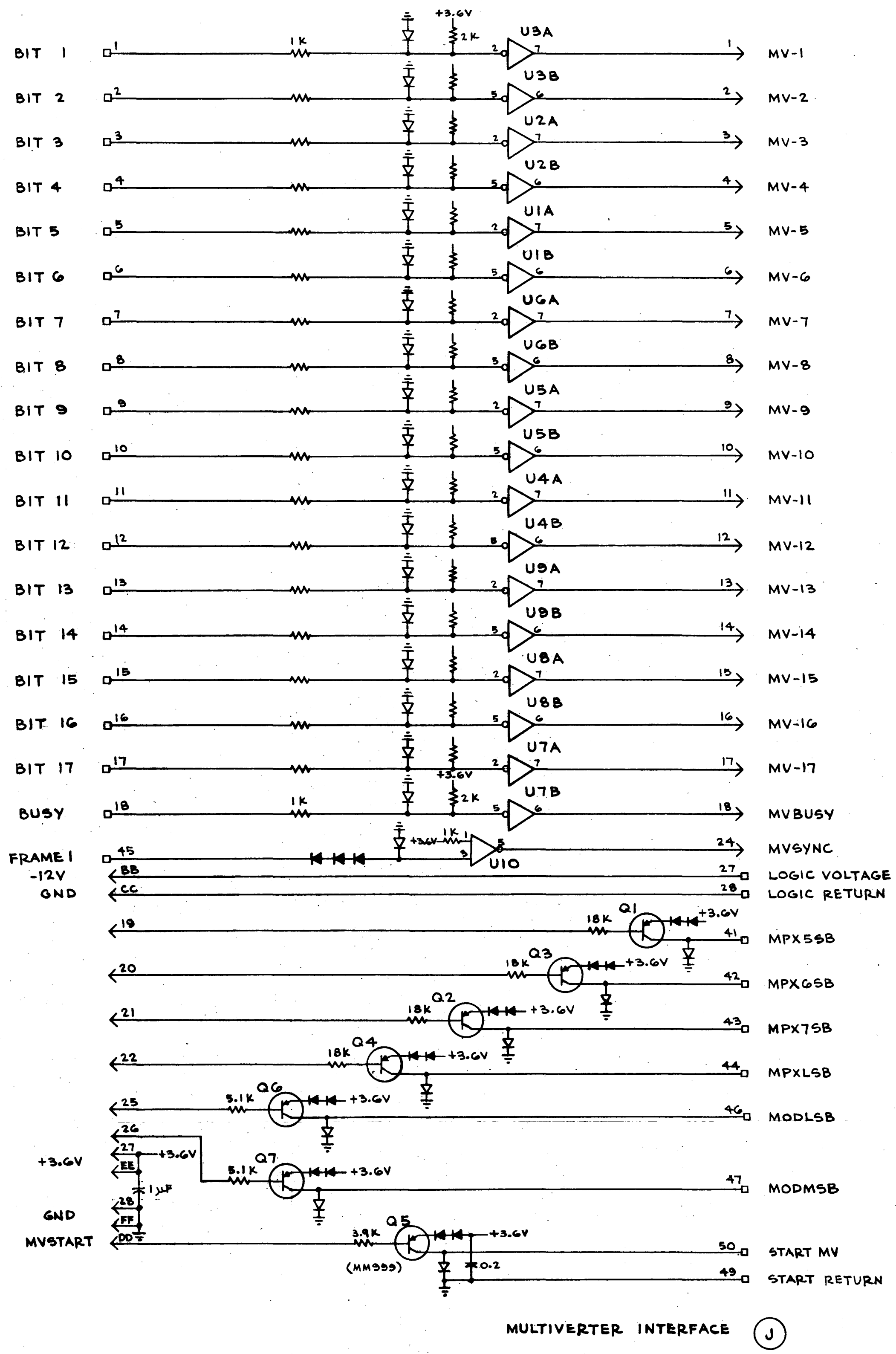




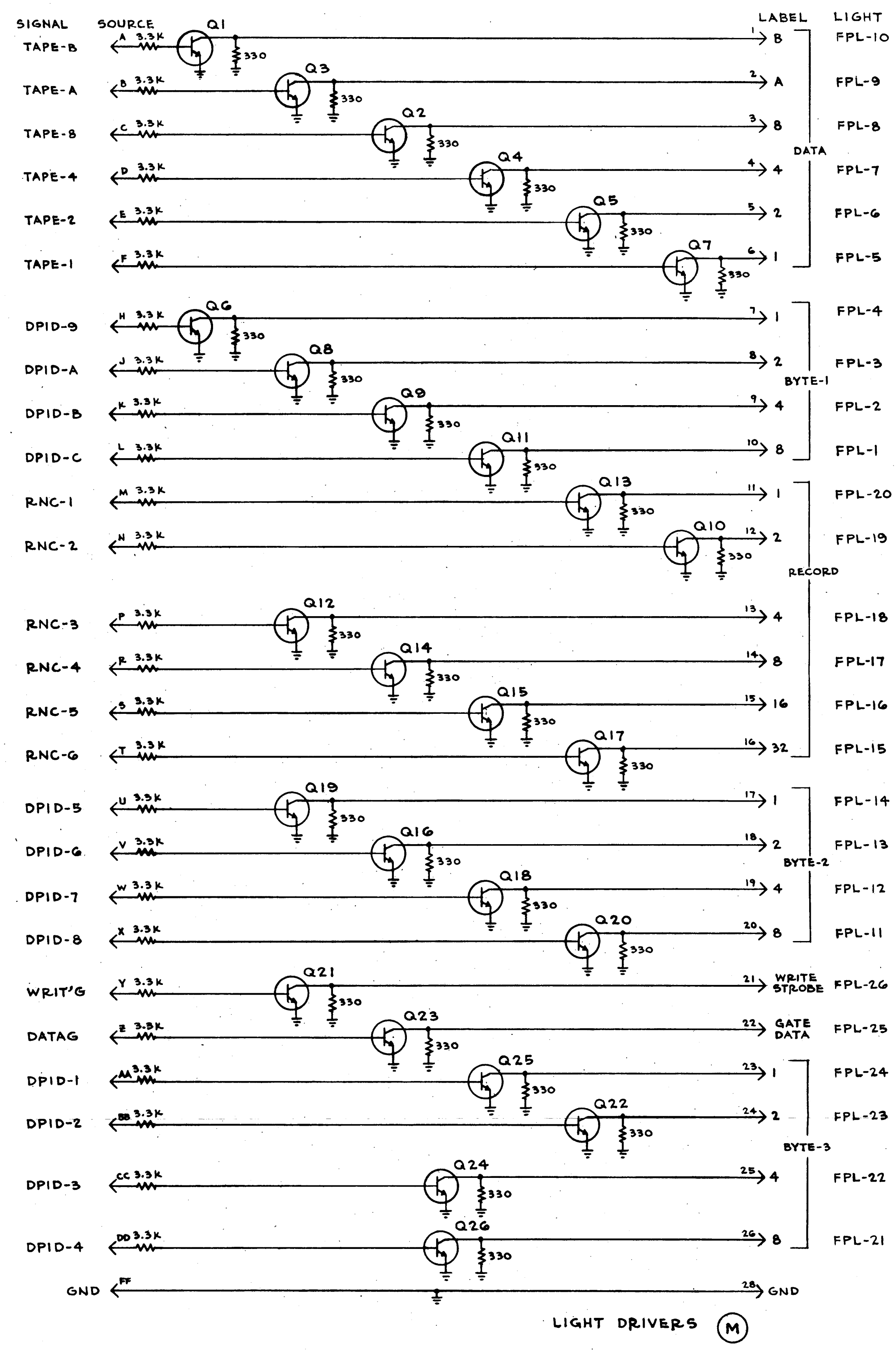




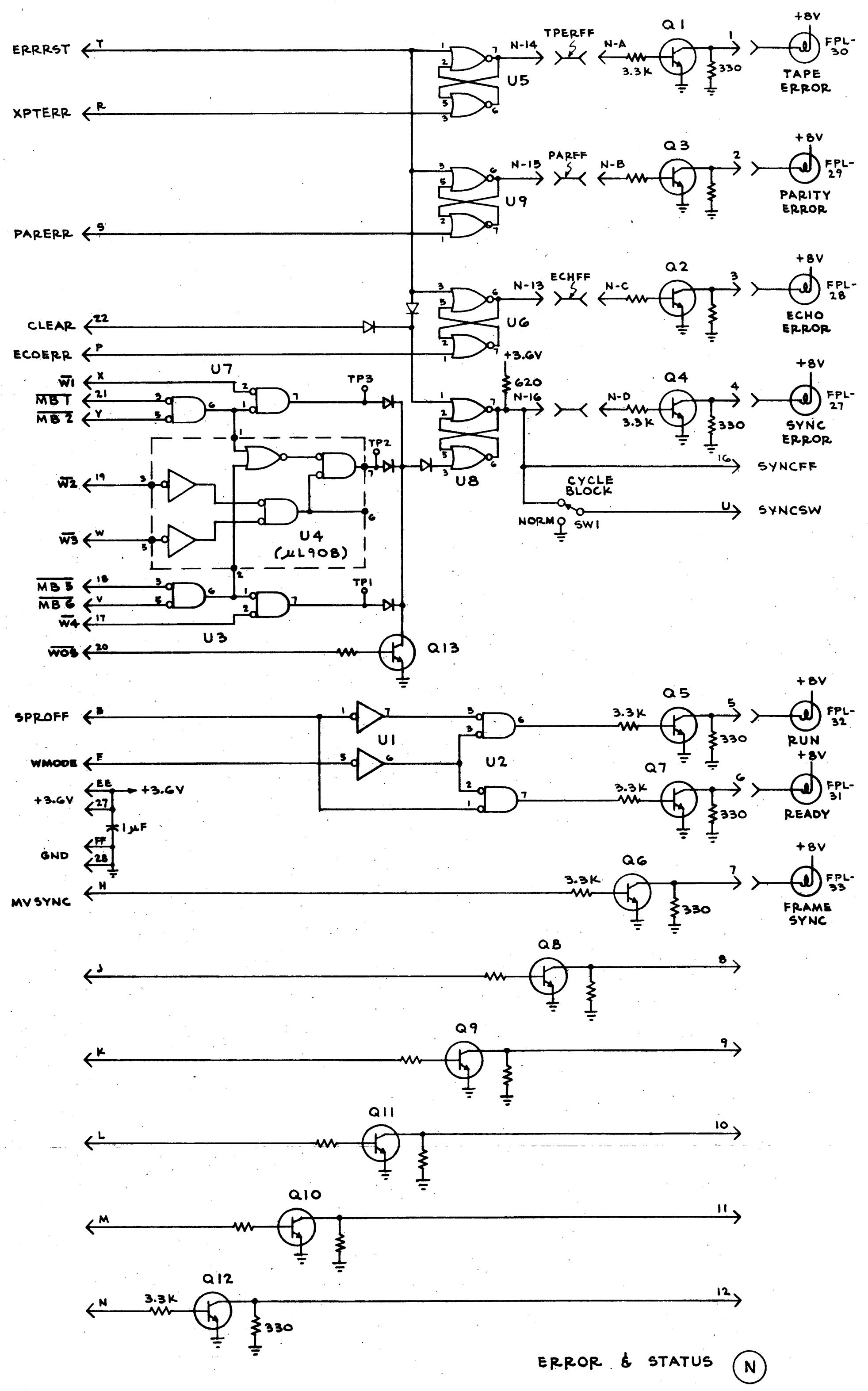




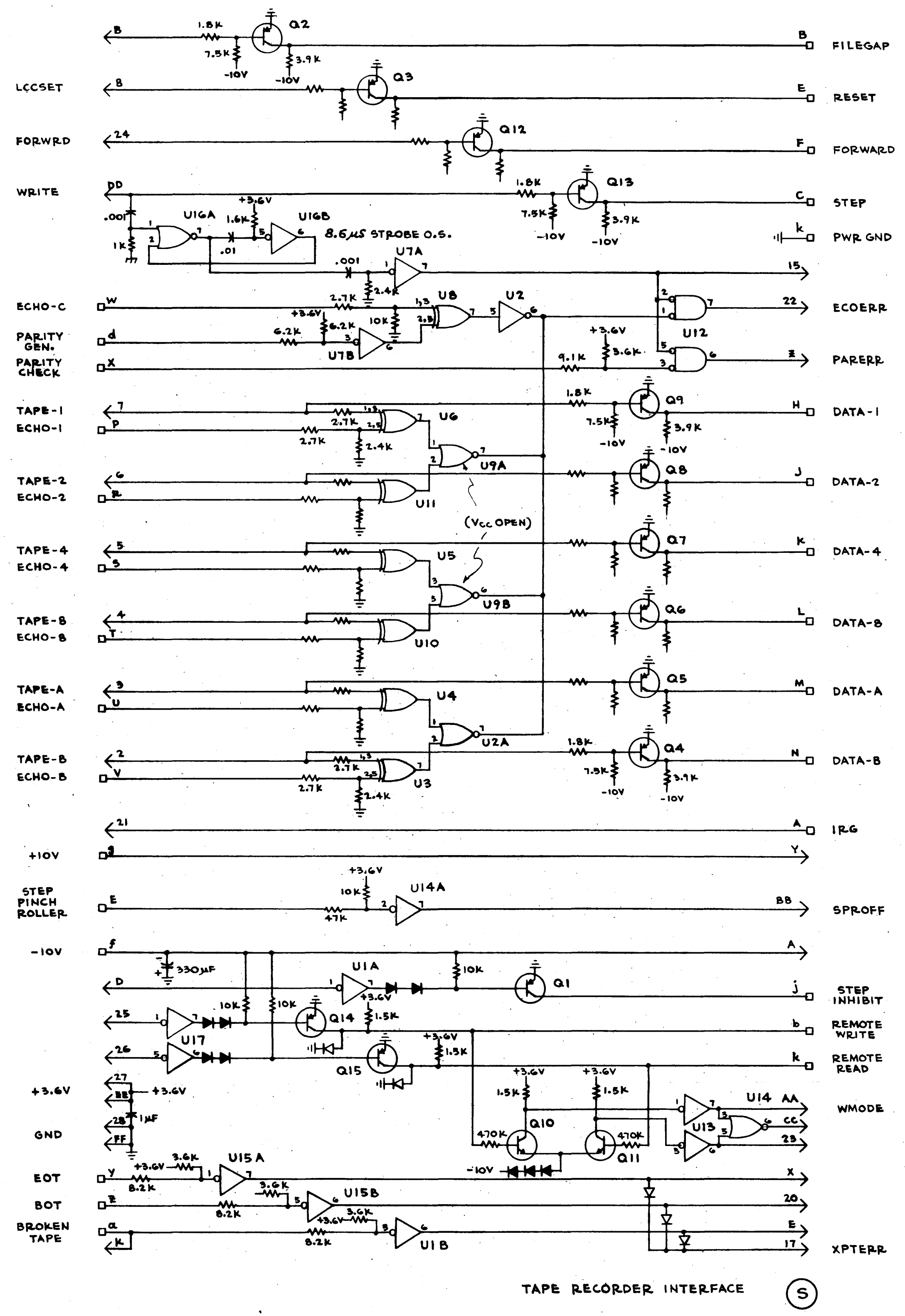




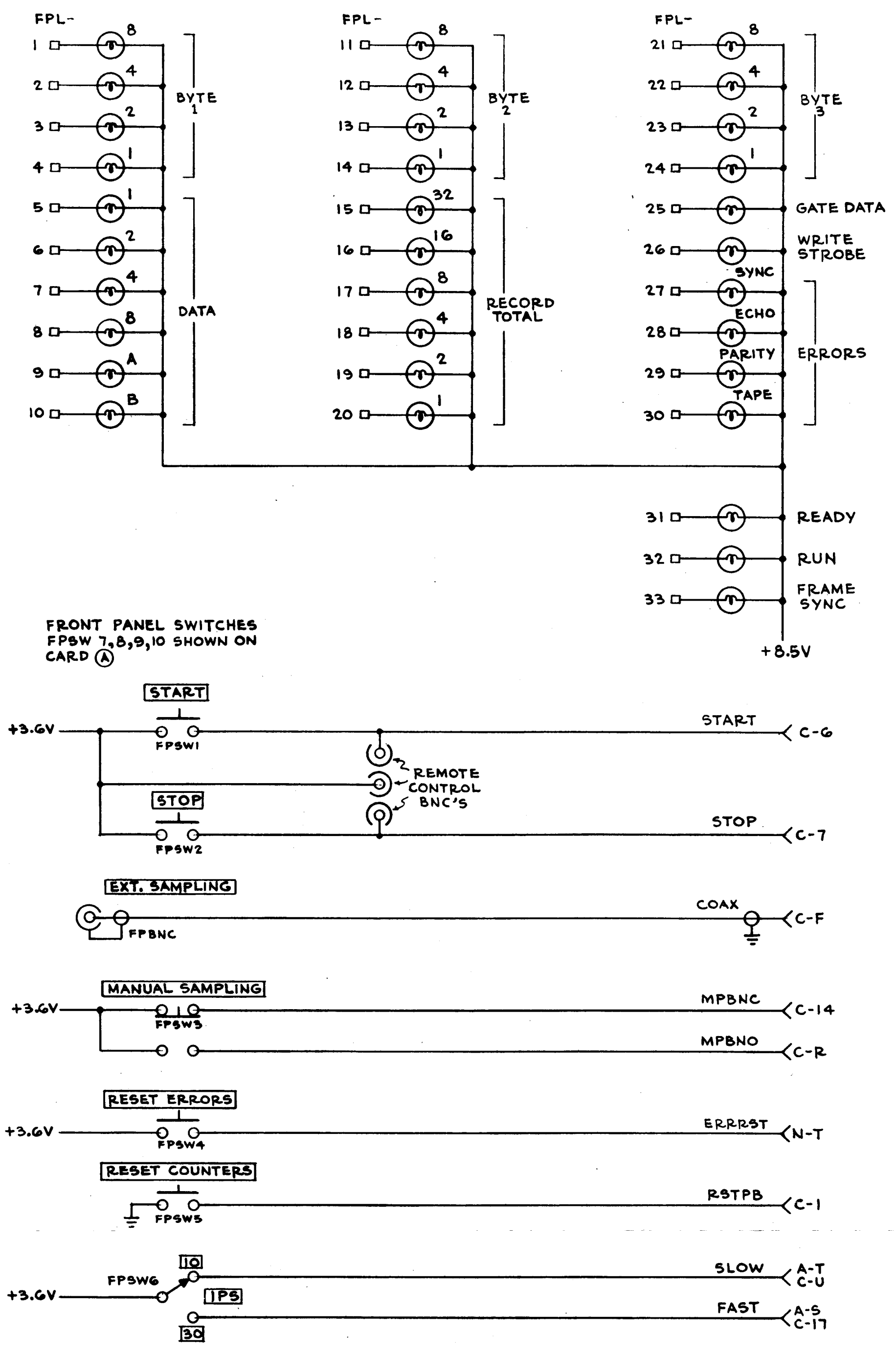

FRONT PANEL 

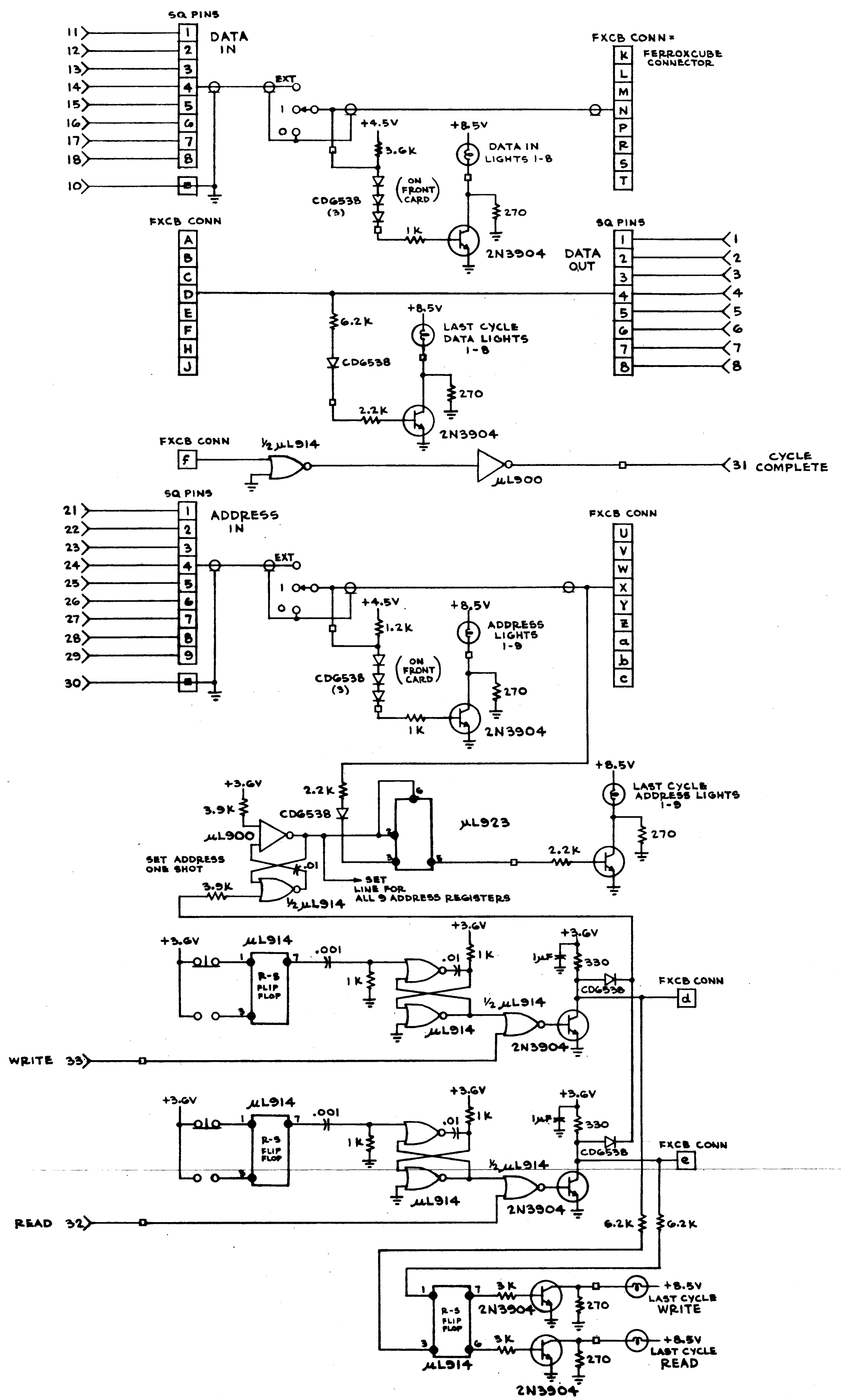

BUFFER MEMORY 

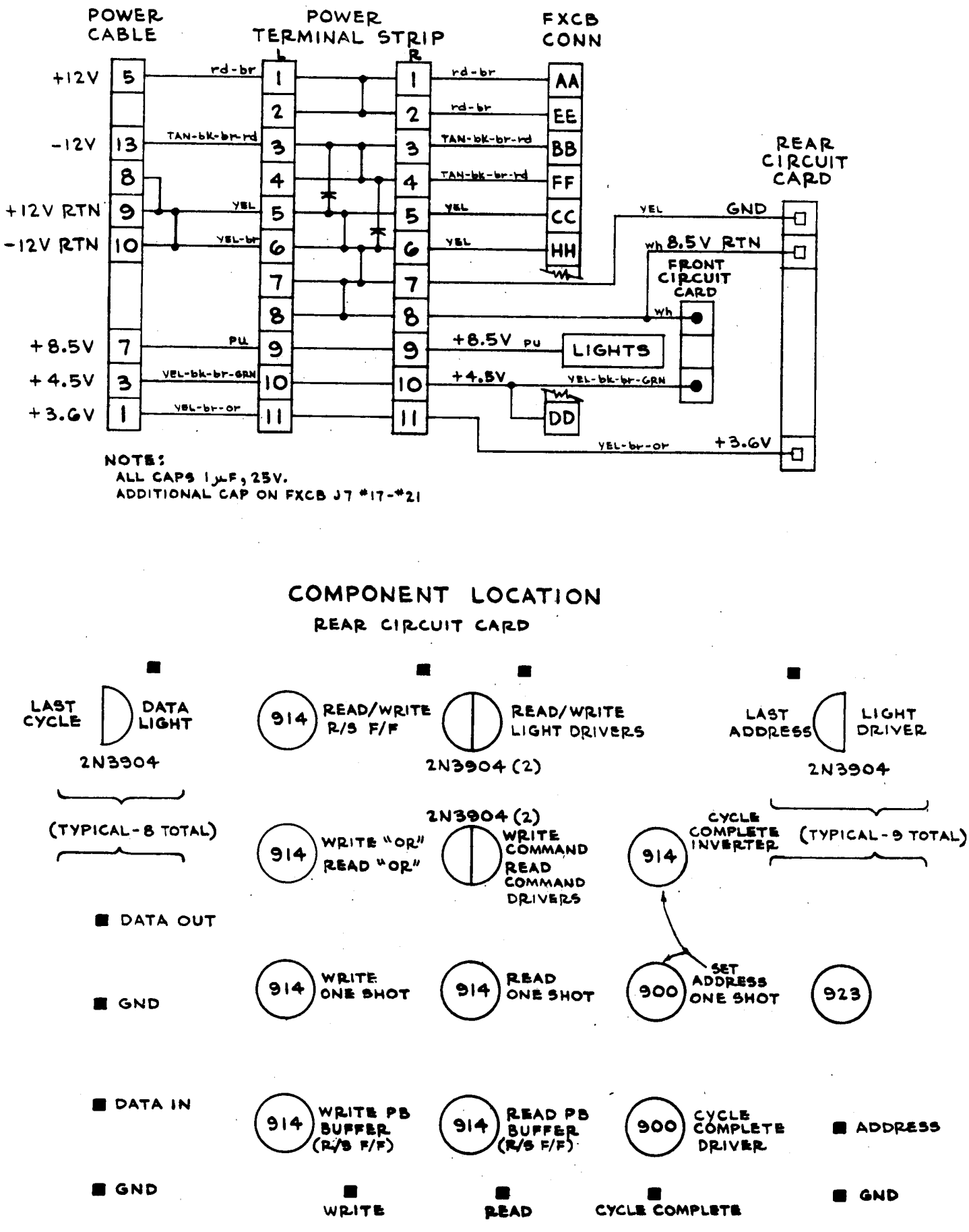

BUFFER MEMORY

SHEET 2 OF 2 


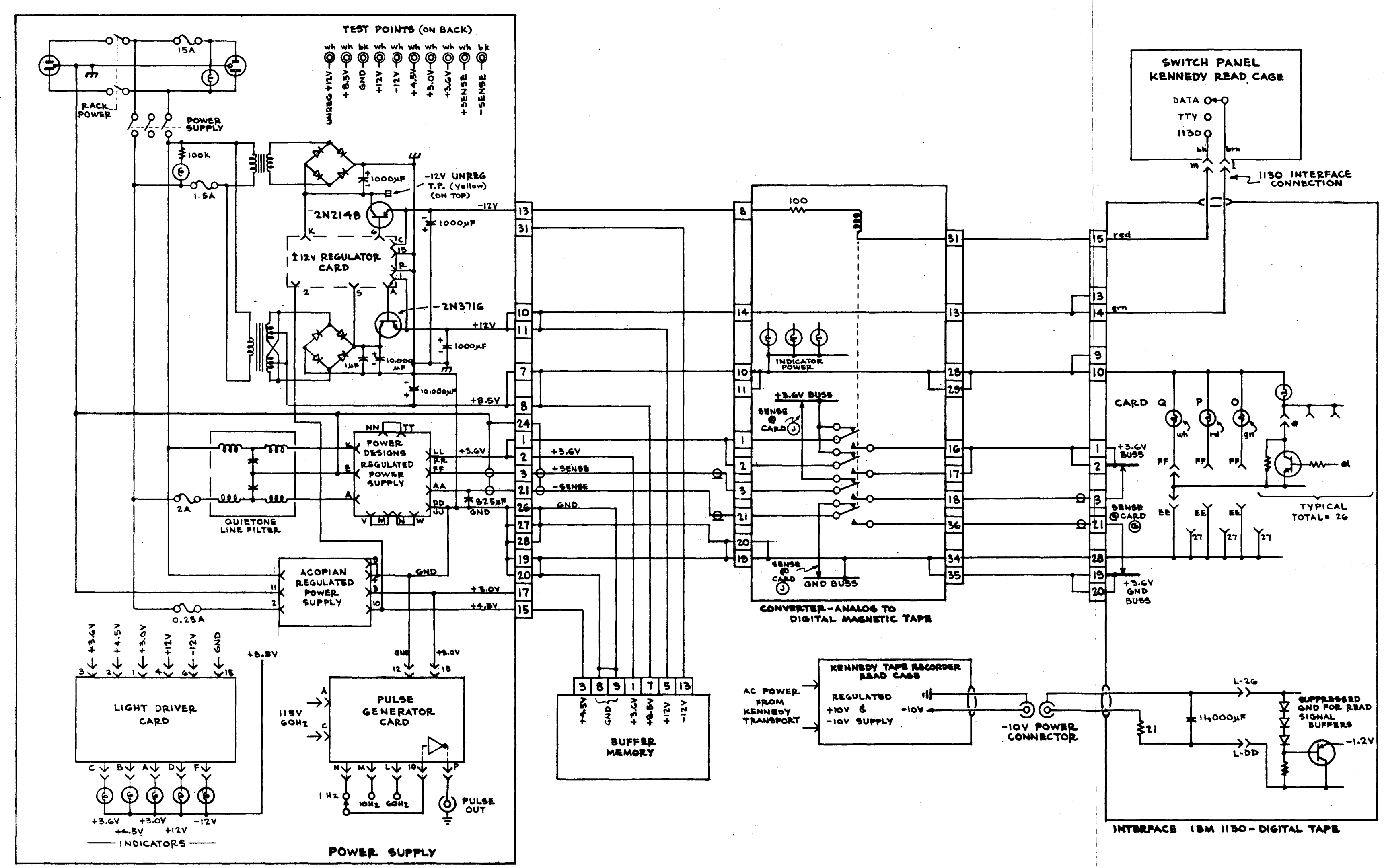




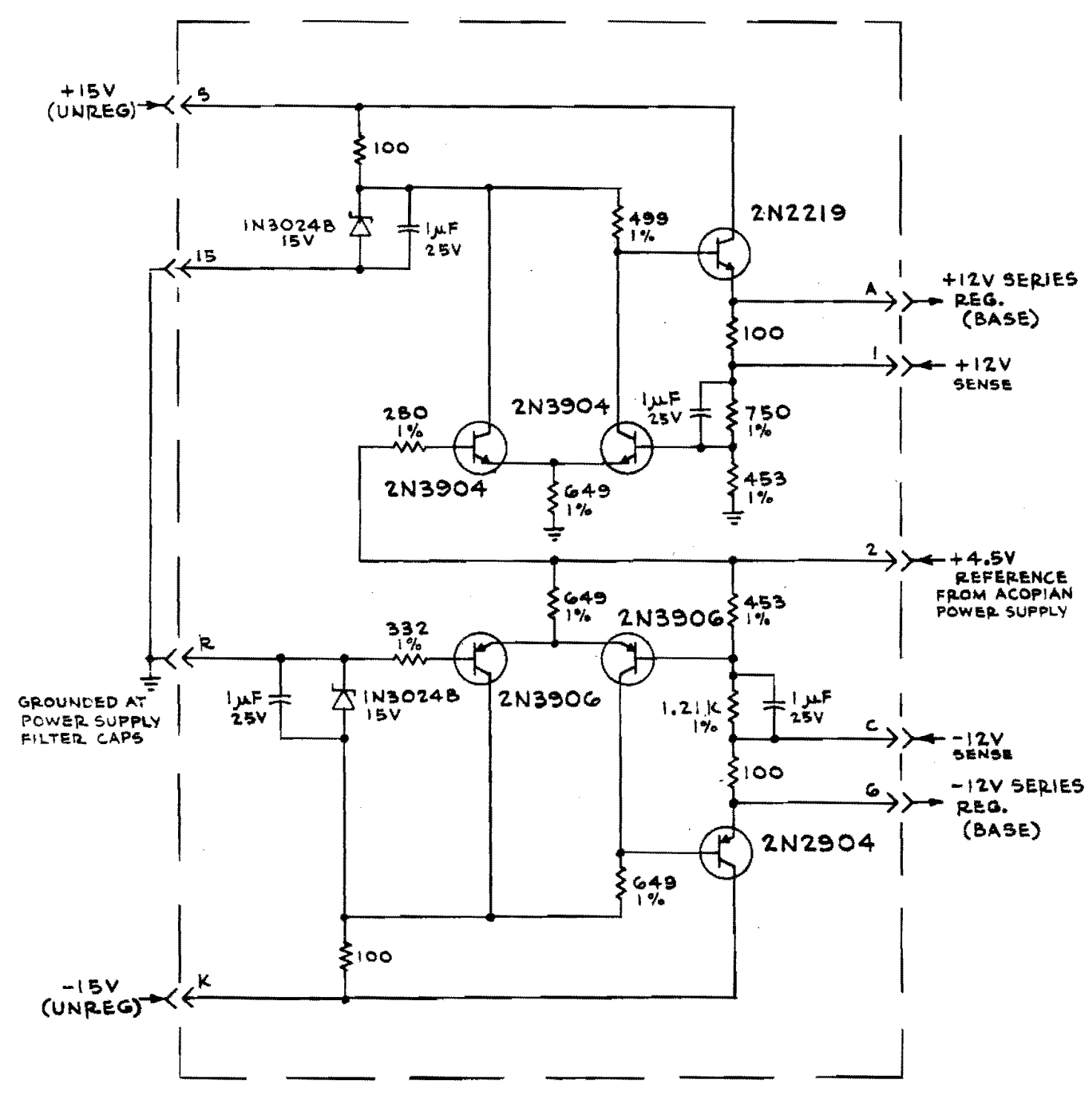

\pm I2V REGULATOR 


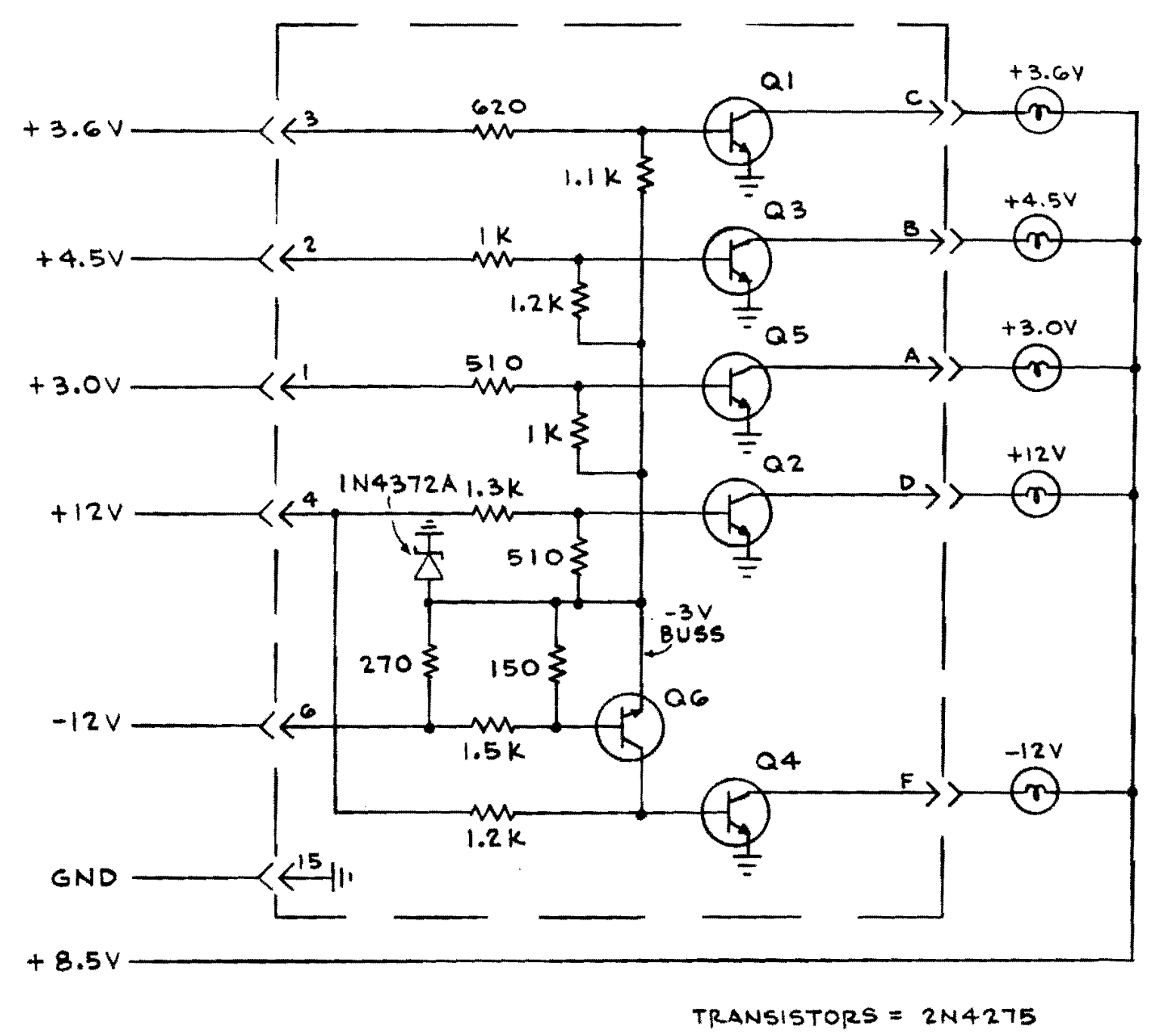

POWER SUPPLY

LIGHT DRIVER CARD 

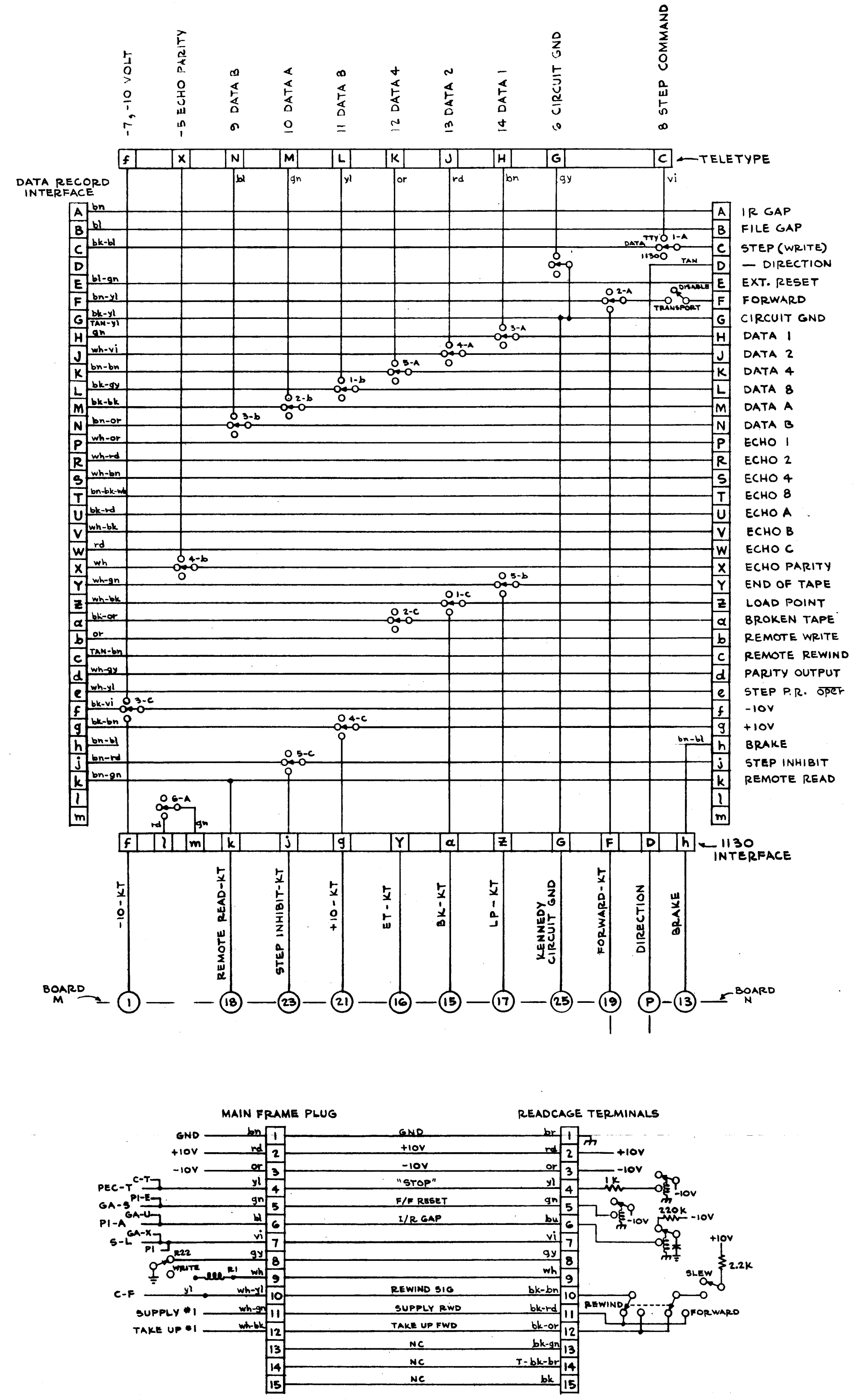

READ CAGE SWITCH-DATA-TTY- 1130 


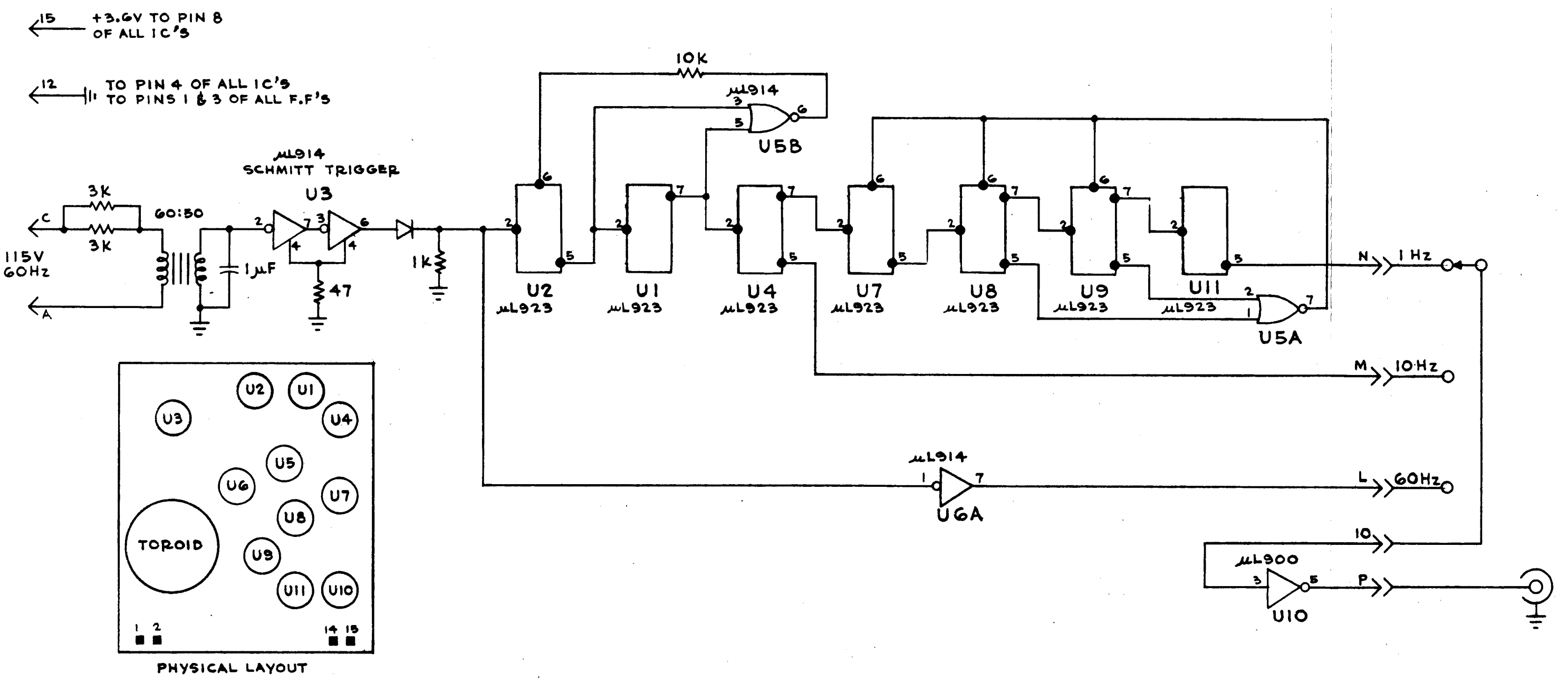

PULSE GENERATOR CARD 
AFPTIDI: II

\section{CAPD LAYOUTS and IIRITG LISTS}

CAD A - Fecond Length Counter and In Gap Gererator

CHD B - Sunchronizer and Coincicence Generator

Cfin C - Start/Stop Control and Clock

CHD D - Data Sampler and Shirters

CARD I - Nacnetic Tape Fomatter

CARD F - Unload Address Counter

CAID G - Load Aldress Counter

CAPD H - Vemory Interface

CARD I - Norory Formatter

CHD J - Hutiventen Interface

CARD H - Light Deivers

CAPD N- Error and Status

CAPD 5 - Tape Record Interface

FP - ront Panel Lients and Sritches. 
Card A - Record Length Counter \& IR Gap Generator 70 Conn. Signal Pin Ckt. Ckt. Pin Signal Conn. FPSW8 RLC-E2 A in U5

$\begin{array}{lllll}\text { GND } & \text { UL923JK } & \text { B } & \text { in } & \text { U5 } \\ \text { FPSW7 } & \text { RLC-U4 } & \text { C } & \text { in } & \text { U3 } \\ \text { B-8 } & \text { WRITE } & \text { D } & \text { in } & \text { U1 } \\ \text { GND } & \text { UL923JK } & \text { E } & \text { in } & \text { U1 } \\ \text { FPSW7 } & \text { RLC-U2 } & \text { F } & \text { in } & \text { U2 } \\ \text { C-12 } & \text { RESET1 } & \text { H } & \text { even U } \\ \text { FPSW10 } & \text { RLC-F2 } & \text { J } & \text { in } & \text { U11 } \\ \text { GND } & \text { UL923JK } & \text { K } & \text { in } & \text { U11 } \\ \text { FPSW9 } & \text { RLC-S4 } & \text { L } & \text { in } & \text { U9 } \\ \text { A-1 } & \text { RLCARY } & \text { M } & \text { in } & \text { U7 } \\ \text { GND } & \text { UL923JK } & \text { N } & \text { in } & \text { U7 } \\ \text { FPSW9 } & \text { RLC-S2 } & \text { P } & \text { in } & \text { U8 } \\ \text { n.C. } & & \text { R } & & \end{array}$

U6 in 1 RLC-E4 FPSW8 4 out RLCARY A-M $\mathrm{U1,U3,U5} 3$ RESET1 $\mathrm{C}-12$ $\mathrm{U} 1$ in 4 RLC-U1 FPSW7 U4 in 5 RLC-E1 FPSW8 $\mathrm{U} 1$ in 6 CLREND C-D U2,U4,U6 7 UL923JK GND U12 in 8 RLC-F4 FPSW10 U9 in 9 UL923JK GND U7,9,11 10 RESET $1 \quad \mathrm{C}-12$ U7 in 11 RLC-S1 FPSW9 U10 in 12 RLC-F1 FPSW10 U8, 10,12 13 UL923JK GND U12 out 14 OVFLOW A-V

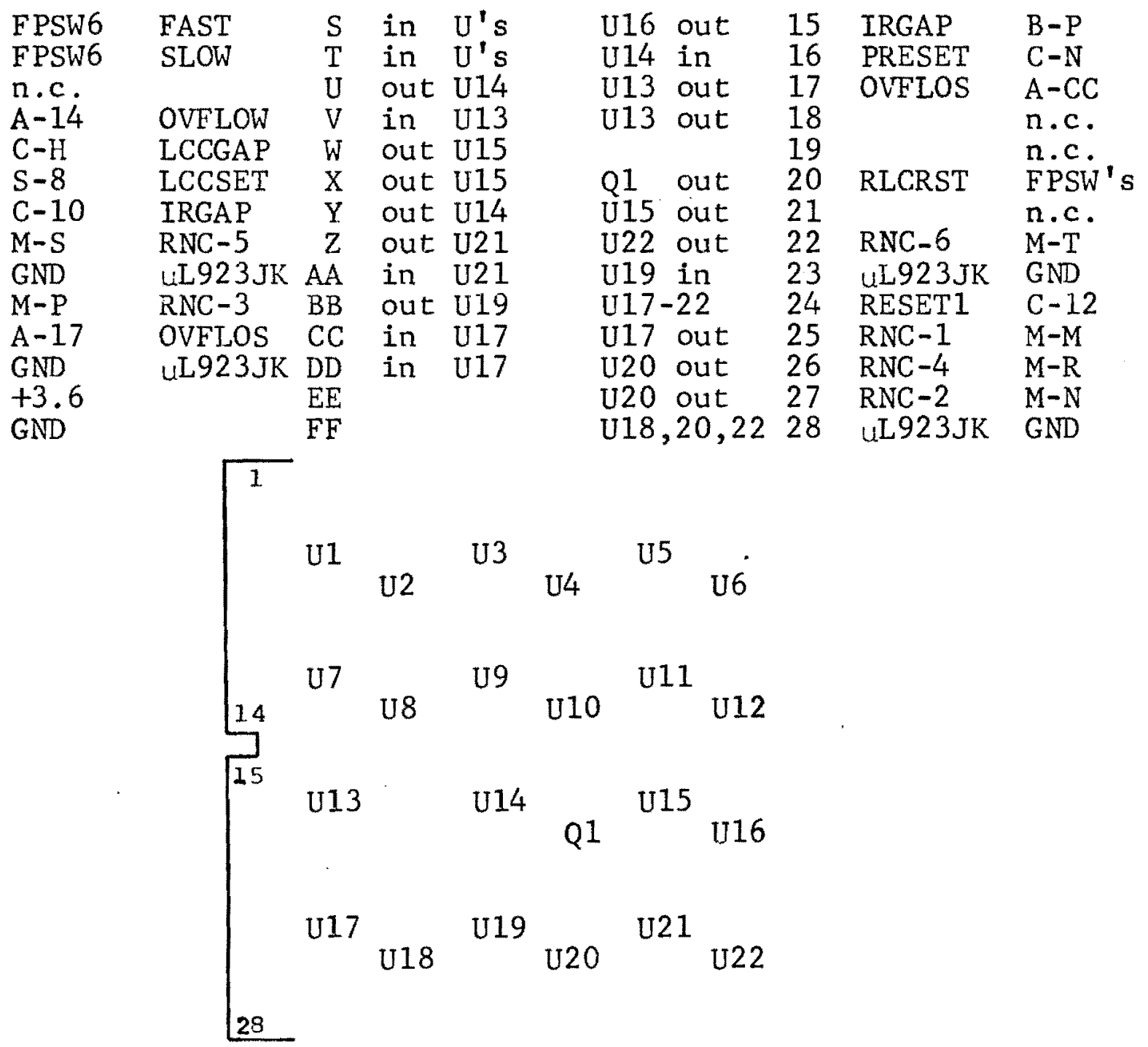


Card B - Synchronizer \& Coincidence Generator 71 Conn. Signal Pin Ckt. $\underline{\text { Ckt. }}$. Pin Signal Conn. n.c. I -9 MVJAM

B U6 in

N-16 SYNCFF

D-T

SHIFT

in $\mathrm{U} 1$

$\mathrm{U} 1$ in

1 CLEAR

U3 out

U5 in

U2 out

2

U8 in

$U^{\prime} s$ out

$\overline{L O A D}^{\prime} G$

C-4

G-7

NOLOAD

D out U10

$E-10$

$\frac{\text { FILLER }}{\text { FOR!VR }}$

$\mathrm{N}-20$

WOS

D-L

C

$\mathrm{F}$ in $\mathrm{U} 8$

$\mathrm{H}$ in $\mathrm{U13}$

U6 out

$\mathrm{K}$ in $\mathrm{U} 14$

D-AA

INDIRC

$C-V$

CLOCK

$\mathrm{D}-17$

WRDRST

A -15

IRGAP $\mathrm{P}$ in U17

$\mathrm{D}-12$

$\overline{\mathrm{LOAD} G} \mathrm{R}$ in $\mathrm{U} 16$

H -19

UNLOAD $S$ out U20

$\mathrm{H}-\mathrm{L}$

$$
\text { CYCOMP }
$$

$\mathrm{E}-\mathrm{P}, \mathrm{F}-\mathrm{M}$

UNCLK

$\mathrm{G}-\mathrm{P}$

LDCO -1

G-12

LDCO-2

$\mathrm{G}-13$

LDCO -3

$\mathrm{G}-\mathrm{X}$

LDCO-4

$G-19$

LDCO-5

G-20

LDCO-6

G-EE

LDCO-7

G-26

$\mathrm{G}-27$

$+3.6 \mathrm{~V}$

LDCO-8

GND

$\mathrm{L}$ in $\mathrm{U} 14$

$M$ in U19

$\mathrm{N}$ out U15

$\mathrm{T}$ in $\mathrm{U} 30$

$\mathrm{U}$ out U30

$\mathrm{V}$ in $\mathrm{U} 23$

$\mathrm{W}$ in $\mathrm{U} 22$

$\mathrm{X}$ in $\mathrm{U} 2 \mathrm{I}$

$\mathrm{Y}$ in $\mathrm{U} 28$

$\mathrm{Z}$ in $\mathrm{U} 27$

$\mathrm{AA}$ in $\mathrm{U} 26$

$B B$ in $U 33$

$\mathrm{CC}$ in $\mathrm{U} 32$

$\mathrm{DD}$ in U31

EE

$\mathrm{U} 15$ in

$U^{\prime}$ s in

U12 out

U17 in

U16 in

U18 out

U25 in

U30 out

$\mathrm{U} 23$ in

$\mathrm{U} 22$ in

$\mathrm{U} 21$ in

U28 in

$\mathrm{U} 27$ in

$\mathrm{U} 26$ in

U33 in

U32 in

U31 in
3 BYTRST D-10,G-D

DIRECT D-B

NOUNLD $\mathrm{F}-7$

W4L

COINC

WRITE

W4N

INDIRC

CLOCK

FORCE

IRGAP

LOAD 'G

15

16

17

18

19

20

21

22

23

24

25

26

27

28

WRIT 'G M-Y

LOAD D-11

LDCLK

G-M

UNCO-1 F-P

UNCO -2

UNCO-3

$\mathrm{F}-12$

UNCO-4

UNCO-5

UNCO -6

UNCO -7

UNCO-8

UNCO -9

$\mathrm{F}-13$

$\mathrm{F}-\mathrm{X}$

$\mathrm{F}-19$

$\mathrm{F}-20$

$\mathrm{F}-\mathrm{EE}$

$\mathrm{F}-26$

$\mathrm{F}-27$

$+3.6 \mathrm{~V}$

GND

\begin{tabular}{llllll}
\hline 1 & U1 & U2 & U3 & U4 & U5 \\
& U6 & U7 & U8 & U9 & U10 \\
& U11 & U12 & U13 & U14 & U15 \\
$\frac{14}{15}$ & U16 & U17 & U18 & U19 & U20 \\
& U21 & U22 & U23 & U24 & U25 \\
& U26 & U27 & U28 & U29 & U30 \\
& U31 & U32 & U33 & U34 & U35
\end{tabular}


Conn. Signal Pin Ckt. Ckt. Pin Signal Conn.

n.c. $A$ U7 in 1 RSTPB FPSW5

$\begin{array}{llll}\text { B-H } & \text { FORWRD } & \text { B } & \text { out U2 } \\ \mathrm{S}-24 & \text { FORWRD } & \text { C } & \text { out SW1 }\end{array}$

A-6 CLREND D out U4

D-15 CLEAR E out U1

FPBNC COAX $F$ in U14

$A-W$ LCCGAP $H$ in $U 6$

n.c.

n.c.

n.c.

n.c.

A -16

$\mathrm{M}-\mathrm{Z}$

$\mathrm{J}$ in $\mathrm{U} 6$

FPSW3

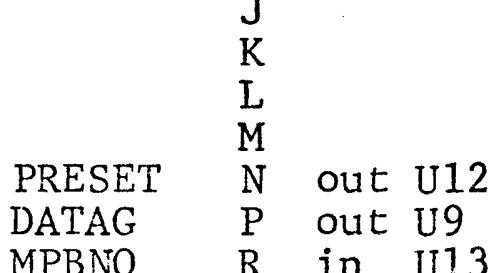

n.c.

$\mathrm{D}-2$

$\begin{array}{lll} & \text { S } & \\ \text { DSAMPL } & \text { T } & \text { out U14 } \\ \text { SLOW } & \text { U } & \text { in U18 } \\ \text { CLOCK } & \text { V } & \text { out U17 } \\ & \text { W } & \\ & \text { X } & \\ & \text { Y } & \\ \text { Z } & \\ \text { AA } & \\ \text { BB } & \\ \text { CC } & \\ \text { DD } & \\ \text { EE } & \\ \text { FF } & \end{array}$

FPSW6 SLOW $U$ in U18

B-M,D-1 $\overline{\text { CLOCK }} \quad \mathrm{V}$ out U17

n.c.

n.c.

n.c.

n.c.

n.c.

n.c.

n.c.

n.c.

$+3.6 \mathrm{~V}$

GND

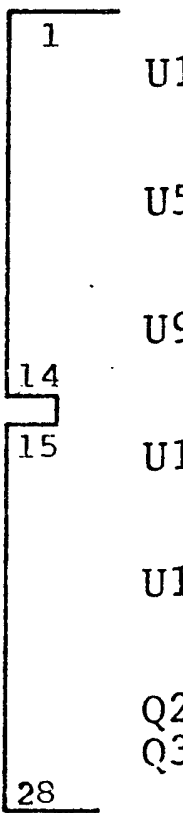

$\begin{array}{llllll}\text { U1 } & \text { U2 } & \text { U3 } & \text { U4 } & \text { Q1 } & \text { I1 }\end{array}$

$\begin{array}{lllll}\text { U5 U6 } & \text { U7 } & \text { U8 } & \text { SW1 }\end{array}$

$\begin{array}{llll}\text { U9 } & \text { U10 } & \text { U11 } & \text { U12 }\end{array}$

U13 U14 U15

SW2

U16 U17 U18

SW3

Q2
Q3

Q4
Q5

Q6

CLEAR $\quad \mathrm{B}-1, \mathrm{~N}-22$

SYNCFF N-16

START FPSW1

STOP FPSW2

COINC B-7

n.c.

$A-Y$

$\begin{array}{ll}\text { RESET1 } & A-3, \text { etc } \\ \text { RESET2 } & F^{\prime} S, G^{\prime} s\end{array}$

MPBNC FPSW3

$\mathrm{U} 15$ in 15 SYNCSW $\mathrm{N}-\mathrm{U}$

U18 in 17 n.c.

FAST FPSW6

n.c.

CLOCK B-11

n.c.

n.c.

n.c.

n.c.

n.c.

n.c.

n.c.

$+3.6 \mathrm{~V}$

GND 
Conn. Signal Pin Ckt. Ckt. Pin Signal Conn.

\begin{tabular}{|c|c|c|c|c|c|c|c|c|c|}
\hline $\begin{array}{l}E-23 \\
B-4 \\
N-U \\
n \cdot c . \\
H-L \\
H-10 \\
E-7 \\
E-8 \\
E-9 \\
B-K, N- \\
E-11, X \\
E-12,19 \\
E-13, W \\
E-14,17\end{array}$ & $\begin{array}{l}\overline{\text { CYCONP }} \\
\text { CYCOMP } \\
\bar{A} \\
\frac{\bar{B}}{C} \\
\frac{C}{\overline{W I}} \\
\frac{\sqrt{2}}{\sqrt{W 3}} \\
\frac{W 4}{W}\end{array}$ & $\begin{array}{l}\text { A } \\
\text { B } \\
\text { C } \\
\text { D } \\
\text { E } \\
\text { F } \\
\text { H } \\
\text { J } \\
\text { K } \\
\text { L } \\
\text { M } \\
\text { N } \\
\text { P } \\
\text { R }\end{array}$ & $\begin{array}{l}\text { in } \\
\text { out } \\
\text { in } \\
\text { out } \\
\text { in } \\
\text { in } \\
\text { out } \\
\text { out } \\
\text { out } \\
\text { out } \\
\text { out } \\
\text { out } \\
\text { out } \\
\text { out }\end{array}$ & $\begin{array}{l}\text { U4 } \\
\text { U4 } \\
\text { U1 } \\
\text { U3 } \\
\text { U5 } \\
\text { U5 } \\
\text { U21 } \\
\text { U31 } \\
\text { U35 } \\
\text { U28 } \\
\text { U22 } \\
\text { U27 } \\
\text { U32 } \\
\text { U33 }\end{array}$ & $\begin{array}{l}\text { U26 } \\
\text { U1 } \\
\text { U2 } \\
\text { U's } \\
\text { U1 } \\
\text { U20 } \\
\text { U25 } \\
\text { U30 } \\
\text { U7 } \\
\text { U's } \\
\text { U6 } \\
\text { U10 } \\
\text { U9 } \\
\text { U12 }\end{array}$ & $\begin{array}{l}\text { in } \\
\text { in } \\
\text { in } \\
\text { in } \\
\text { out } \\
\text { out } \\
\text { out } \\
\text { out } \\
\text { in } \\
\text { in } \\
\text { out } \\
\text { out } \\
\text { out } \\
\text { out }\end{array}$ & $\begin{array}{l}1 \\
2 \\
3 \\
4 \\
5 \\
6 \\
7 \\
8 \\
9 \\
10 \\
11 \\
12 \\
13 \\
14\end{array}$ & $\begin{array}{l}\overline{C L O C K} \\
\text { DSAMPL } \\
\text { MVBUSY } \\
\text { MVSYNC } \\
\text { MVSTRT } \\
\frac{\text { CI }}{\mathrm{C} 2} \\
\overline{C 3} \\
\text { MVJAM } \\
\text { BYTRST } \\
\text { LOAD } \\
\text { LOAD G } \\
\text { LOAD 'G }\end{array}$ & $\begin{array}{l}C-V \\
C-T \\
J-18 \\
J-24 \\
J-D D \\
I-V \\
I-W \\
I-X \\
I-9 \\
B-3 \\
H-20 \\
B-R \\
B-14 \\
n . C .\end{array}$ \\
\hline $\begin{array}{l}\text { C- } 19 \\
\text { B-D } \\
\text { n.c. } \\
\text { n.c. } \\
\text { n.c. } \\
\text { n.c. } \\
\text { n.c. } \\
\text { n.c. } \\
B-L \\
\text { n.c. } \\
\text { n.c. } \\
\text { n.c. } \\
+3.6 \mathrm{~V} \\
\text { GND }\end{array}$ & $\begin{array}{l}\text { CLOCK } \\
\text { SHIFT }\end{array}$ & $\begin{array}{l}\mathrm{S} \\
\mathrm{T} \\
\mathrm{U} \\
\mathrm{V} \\
\mathrm{W} \\
\mathrm{X} \\
\mathrm{Y} \\
\mathrm{Z} \\
\mathrm{AA} \\
\mathrm{BB} \\
\mathrm{CC} \\
\mathrm{DD} \\
\mathrm{EE} \\
\mathrm{FF}\end{array}$ & $\begin{array}{l}\text { in } \\
\text { in } \\
\text { out }\end{array}$ & $\begin{array}{l}\text { U14 } \\
\text { U15 } \\
\text { U19 }\end{array}$ & $\begin{array}{l}\text { U14 } \\
\text { U's }\end{array}$ & in & $\begin{array}{l}15 \\
16 \\
17 \\
18 \\
19 \\
20 \\
21 \\
22 \\
23 \\
24 \\
25 \\
26 \\
27 \\
28\end{array}$ & $\begin{array}{l}\overline{\text { CLEAR }} \\
\text { WRDRST }\end{array}$ & $\begin{array}{l}C-3 \\
n \cdot c . \\
B-N \\
\text { n.c. } \\
\text { n.c. } \\
\text { n.c. } \\
\text { n.c. } \\
\text { n.c. } \\
\text { B-10 } \\
\text { n.c. } \\
\text { n.c. } \\
\text { n.c. } \\
+3.6 \\
\text { GND }\end{array}$ \\
\hline
\end{tabular}

\begin{tabular}{|c|c|c|c|c|c|}
\hline 1 & & U1 & U2 & U3 & U4 \\
\hline & U5 & & U6 & U7 & U8 \\
\hline & U9 & $\mathrm{U} 10$ & U11 & U12 & U13 \\
\hline 14 & U14 & U15 & U16 & U17 & U18 \\
\hline & U20 & U21 & U22 & U23 & U24 \\
\hline & U25 & U26 & U27 & U28 & U29 \\
\hline 28 & U30 & U31 & U32 & U33 & U34 \\
\hline
\end{tabular}


Conn. Signal Pin Ckt. Ckt. Pin Signal Conn.

G-4 DPID-1 A in U2

$G-F$ DPID-2 $B$ in U2

G-C DPID-3 $C$ in U1

G-5 DPID -4 D in U1

G-A DPID-5 $E$ in U5

G-1 DPID $-6 \quad F$ in U5

$\mathrm{F}-4 \quad \mathrm{DPID}-7 \quad \mathrm{H}$ in $\mathrm{U} 4$

$\mathrm{F}-\mathrm{F} \quad \mathrm{DPID}-8 \mathrm{~J}$ in U4

$\mathrm{F}-\mathrm{C}$ DPID-9 $\mathrm{K}$ in U8

$\mathrm{F}-5$ DPID-A $\mathrm{L}$ in U8

$\mathrm{F}-\mathrm{A}$ DPID-B $\mathrm{M}$ in $\mathrm{U} 9$

$\mathrm{F}-1$ DPID-C $\mathrm{N}$ in U9

$\mathrm{B}-\mathrm{U}$ UNCLK $\mathrm{P}$ in U10

n.c.

$R$ out U22

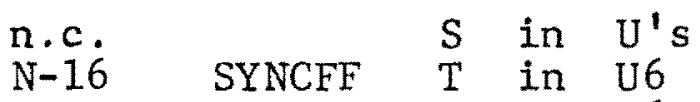

n.c. $U$ in $\mathrm{U} 6$

B-12 FORCE $V$ in $U 6$

$\mathrm{H}-21$ MEM-1 $\mathrm{W}$ in U3

$\mathrm{H}-22$ MEM-2 $\mathrm{X}$ in $\mathrm{U} 7$

$\mathrm{H}-23$ MEM-3 $\mathrm{Y}$ in U1I

$\mathrm{H}-24$ MEM-4 $Z$ in U15

$\mathrm{H}-25$ MEM-5 AA in U19

$\mathrm{H}-26$ MEM-6 BB in U23

$\mathrm{H}-27$ MEM-7 CC in U27

$\mathrm{H}-28$ MEM-8 DD in U3I

$+3.6 \mathrm{~V}$

GND

$\mathrm{EE}$

$\mathrm{FF}$

D's out

1
2
3
4
5

$U^{\prime} s$ in 7

$U^{\prime} s$ in 8

U's in 9

U6 out 10

$\mathrm{U}^{\prime} \mathrm{s}$ in 11

U's in

12

$U^{\prime} s$ in

$U^{\prime} s$ in

$\mathrm{U} 16$ out

U16 out

U17 out

U17 out

13

14

U18 out

U18 out

U3 out

U7 out

U26 out

U30 out

U19 out

15

16

17

18

19

20 TAPE-B

21 MBI

22 MB2

23 W4L

$24 \quad$ W4N

$25 \overline{\mathrm{MB} 5}$

U23 out $26 \quad \overline{M B 6}$

27

28

n. . .

n.c.

n.c.

n.c.

n.c.

n.c.

$\mathrm{D}-\mathrm{H}$

$D-J$

$D-K$

$B-F$

$\mathrm{D}-\mathrm{M}$

$\mathrm{D}-\mathrm{N}$

$\mathrm{D}-\mathrm{P}$

$D-R$

$\mathrm{S}-7, \mathrm{M}-\mathrm{F}$

$\mathrm{S}-6, \mathrm{M}-\mathrm{E}$

$S-5, M-D$

$\mathrm{S}-4, \mathrm{M}-\mathrm{C}$

$S-3, M-B$

$\mathrm{S}-2, \mathrm{M}-\mathrm{A}$

$\mathrm{N}-21$

$\mathrm{N}-\mathrm{Y}$

B $-6, D-A$

B-9

$\mathrm{N}-18$

$\mathrm{N}-\mathrm{V}$

$+3.6 \mathrm{~V}$

GND

\begin{tabular}{|lllll}
\hline 1 & & & & \\
& $\mathrm{U} 1$ & $\mathrm{U} 2$ & $\mathrm{Q} 1$ & $\mathrm{U} 3$ \\
& $\mathrm{U} 4$ & $\mathrm{U} 5$ & $\mathrm{U} 6$ & $\mathrm{U} 7$ \\
& $\mathrm{U} 8$ & $\mathrm{U} 9$ & $\mathrm{U} 10$ & $\mathrm{U} 11$ \\
14 & $\mathrm{U} 12$ & $\mathrm{U} 13$ & $\mathrm{U} 14$ & $\mathrm{U} 15$ \\
& $\mathrm{U} 16$ & $\mathrm{U} 17$ & $\mathrm{U} 18$ & $\mathrm{U} 19$ \\
& $\mathrm{U} 20$ & $\mathrm{U} 21$ & $\mathrm{U} 22$ & $\mathrm{U} 23$ \\
& $\mathrm{U} 24$ & $\mathrm{U} 25$ & $\mathrm{U} 26$ & $\mathrm{U} 27$ \\
& $\mathrm{U} 28$ & $\mathrm{U} 29$ & $\mathrm{U} 30$ & $\mathrm{U} 31$ \\
& & & &
\end{tabular}


Conn. Signal Pin Ckt. Ckt. Pin Signal Conn.

\begin{tabular}{|c|c|c|c|c|c|c|c|c|c|}
\hline $\begin{array}{l}\text { E-M } \\
\text { GND }\end{array}$ & $\begin{array}{l}\text { DPID-B } \\
\text { UL923JK }\end{array}$ & $\begin{array}{l}\mathrm{A} \\
\mathrm{B}\end{array}$ & & $\begin{array}{l}\text { U5 } \\
\text { U's }\end{array}$ & $\begin{array}{l}\text { U6 } \\
\text { U's }\end{array}$ & $\begin{array}{l}\text { out } \\
\text { in }\end{array}$ & $\begin{array}{l}1 \\
2\end{array}$ & $\begin{array}{l}\text { DPID-C } \\
\text { UL923JK }\end{array}$ & $\begin{array}{l}\mathrm{E}-\mathrm{N} \\
G N D\end{array}$ \\
\hline & & C & & U3 & U's & in & & & $C-13$ \\
\hline$G-1$ & PCARY & D & in & & U1 & out & 4 & DPID - 7 & $E-H$ \\
\hline $\mathrm{ND}$ & UL923JK & $\mathrm{E}$ & & $U^{\prime} s$ & U4 & out & 5 & DPID-A & $E-L$ \\
\hline$E-J$ & DPID $=8$ & $\mathrm{~F}$ & out & & $U^{\prime} s$ & in & 5 & RESET2 & $c-13$ \\
\hline i.c. & & H & in & U's & U's & in & 7 & NOUNLD & \\
\hline$-C$ & UNAD - 3 & $\mathrm{~J}$ & out & U12 & U12 & out & 8 & UNCY - 3 & $\mathrm{~F}-\mathrm{V}$ \\
\hline $\mathrm{ND}$ & UL923JK & $\mathrm{K}$ & in & U11 & U9 & in & 9 & UL923JK & GND \\
\hline$[-B$ & UNAD - 2 & L & out & U10 & U's & in & 10 & RESET2 & $c-13$ \\
\hline$-U$ & UNCLK & $\mathrm{M}$ & in & U7 & U8 & out & 11 & UNAD - 1 & $\mathrm{H}-\mathrm{A}$ \\
\hline & UL $923 \mathrm{JK}$ & $\mathrm{N}$ & in & U7 & U9 & out & 12 & UNCO -2 & B-19 \\
\hline $\begin{array}{l}B-18 \\
+3.6 \mathrm{~V}\end{array}$ & UNCO-1 & P & out & U7 & U11 & out & $\begin{array}{l}13 \\
14\end{array}$ & UNCO-3 & $\begin{array}{l}B-20 \\
\text { GND }\end{array}$ \\
\hline$[-F$ & UNAD -6 & S & out & U18 & U18 & out & 15 & UNCY -6 & $\mathrm{~F}-\mathrm{CC}$ \\
\hline ND & uL923JK & & in & U1 & & & 16 & & \\
\hline$H-E$ & UNAD-5 & U & out & U1 & U's & in & 17 & RESET2 & $C-13$ \\
\hline$F-\varepsilon$ & UNCY -3 & $\mathrm{V}$ & in & U1 & U14 & out & 18 & UNAD - 4 & \\
\hline GND & uL923JK & W & in & & & out & 19 & UNCO-5 & $B-22$ \\
\hline B-21 & UNCO-4 & $x$ & out & & & out & 20 & UNCO- 6 & B-23 \\
\hline A.c. & & $\mathrm{Y}$ & in & & $U^{\prime} s$ & in & 21 & NOUNLD & B-5 \\
\hline$H-H$ & UNAD -9 & z & out & & & out & 22 & & \\
\hline GND & UL923JK & $\mathrm{AA}$ & in & U23 & U21 & in & 23 & UI923JK & \\
\hline $\mathrm{H}-\mathrm{J}$ & UNAD -8 & BB & out & & & in & 24 & RESET2 2 & $c-13$ \\
\hline $8-15$ & UNCY - -6 & CC & in & & & out & 25 & UNAD - 7 & $\mathrm{H}-\mathrm{H}$ \\
\hline & بL923JK & DD & in & U. & & it & 26 & UNCO-8 & B-25 \\
\hline$B-2$ & UNCO-7 & & out & U1 & 1. & ut & 27 & UNCO-9 & B-26 \\
\hline & & $\mathrm{FF}$ & in & & & & & & \\
\hline
\end{tabular}

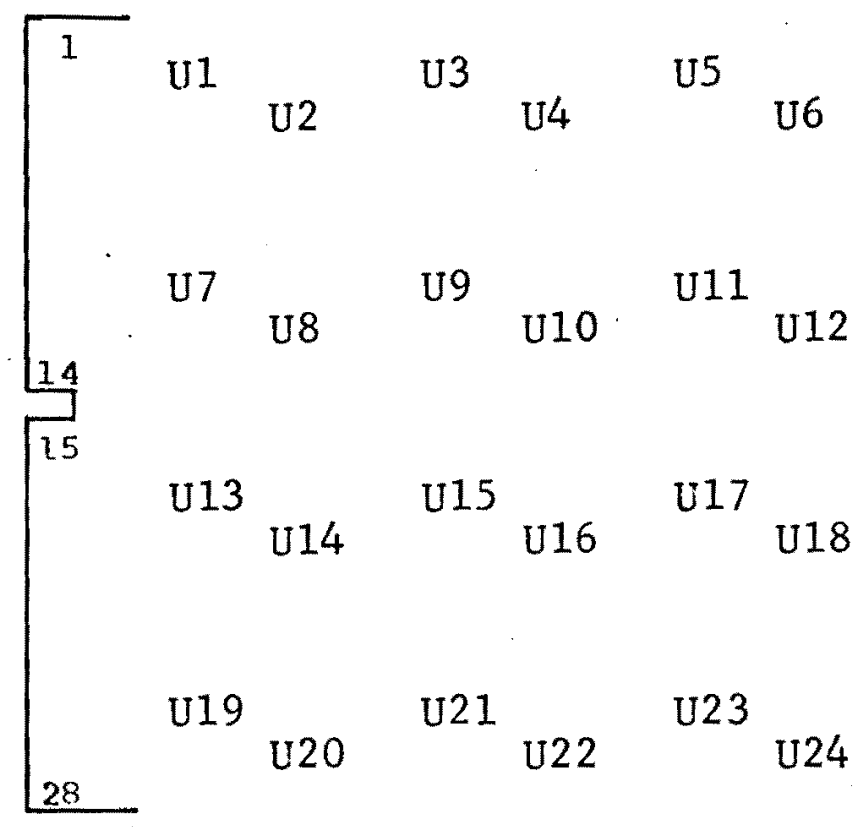


Conn. Sisnal Pin Ckt. Ckt. Pin Signal Conn.

\begin{tabular}{|c|c|c|c|c|c|c|c|c|c|}
\hline$E-E$ & DPID - 5 & A & out & U5 & U6 & out & 15 & DPID-D & $E-F$ \\
\hline GND & UI.923 JK & $\mathrm{B}$ & in & $U^{\prime} s$ & $U^{\prime} s$ & in & 2 & uL923JK & GiD \\
\hline$-C$ & DPID-3 & C & out & U3 & $U^{\prime} s$ & in & 3 & RESET2 & $c-13$ \\
\hline$B-3$ & BYTRST & D & in & vi & U1. & out & 4 & DPID - 1 & $E-A$ \\
\hline SND & LI923JK & E & in & U's & U4 & out & 5 & DPI.D -4 & \\
\hline$;-B$ & DPID - 2 & $\mathrm{~F}$ & out & U2 & $U^{\prime} s$ & in & 6 & RESET2 & $C-13$ \\
\hline a.c. & & $\mathrm{H}$ & in & U's & $U^{\prime} s$ & in & 7 & NOLOAD & \\
\hline-3 & LDAD - 3 & $\mathrm{~J}$ & out & U12 & U12 & out & 8 & LDCY - 3 & $G-V$ \\
\hline ND & UL923.JK & $\mathrm{K}$ & in & U11 & U9 & in & 9 & UL923JK & GND \\
\hline-2 & LDAD-2 & $\mathrm{L}$ & out & U10 & $U^{\prime} s$ & in & 10 & RESET2 & $C-13$ \\
\hline$B-17$ & LDCLK & $M$ & in & U7 & U8 & out & 11 & LDAD - 1 & -1 \\
\hline & UL923.JK & $\mathrm{N}$ & in & U7 & U9 & out & 12 & & \\
\hline $\begin{array}{l}B-V \\
+3.6 V\end{array}$ & LDCO-1 & $\begin{array}{l}P \\
R\end{array}$ & out & U7 & U11 & out & $\begin{array}{l}13 \\
14\end{array}$ & LDCO -3 & $\begin{array}{l}B-X \\
\text { GND }\end{array}$ \\
\hline-6 & & $\mathrm{~S}$ & out & U18 & U18 & out & 15 & LDCY -6 & G-CC \\
\hline NTI & UL 923JK & $\mathrm{T}$ & in & U17 & U15 & in & 16 & UL923JK & \\
\hline$H-5$ & LDAD-5 & $\mathrm{U}$ & out & U16 & U's & in & 17 & & \\
\hline-8 & LDCY - 3 & V & in & U13 & U14 & out & 18 & LDAD - 4 & $\mathrm{H}-4$ \\
\hline GND & UL923JK & W & in & U13 & U15 & out & 19 & LDCO-5 & \\
\hline$B-Y$ & LDCO-4 & $\mathrm{X}$ & out & U13 & U17 & out & 20 & LDCO -6 & $-A A$ \\
\hline n.c. & & $Y$ & in & $U^{\prime} s$ & $U^{\prime} s$ & in & & NOLOAD & \\
\hline$-c$ & LDAD - 9 & 2 & out & $\mathrm{U} 24$ & U24 & out & 22 & & \\
\hline N & UL923JK & $A A$ & in & U23 & U21 & in & 23 & HL923JK & \\
\hline & LDAD -8 & $B B$ & out & U22 & $U^{\prime} s$ & in & 24 & RESET2 & 13 \\
\hline & $D C Y-6$ & $\mathrm{CC}$ & in & U19 & $\mathrm{U} 20$ & out & 25 & LDAD & \\
\hline $3 N$ & $\mu \mathrm{L} 923 \mathrm{JK}$ & $\mathrm{DD}$ & in & U19 & U2 1 & out & 26 & LDCO & \\
\hline DD & LDCO -7 & EE & out & U19 & U23 & out & 27 & & \\
\hline .c. & & FF & in & $U^{\prime} s$ & $U^{\prime} s$ & in & 28 & NOLOAD & \\
\hline
\end{tabular}

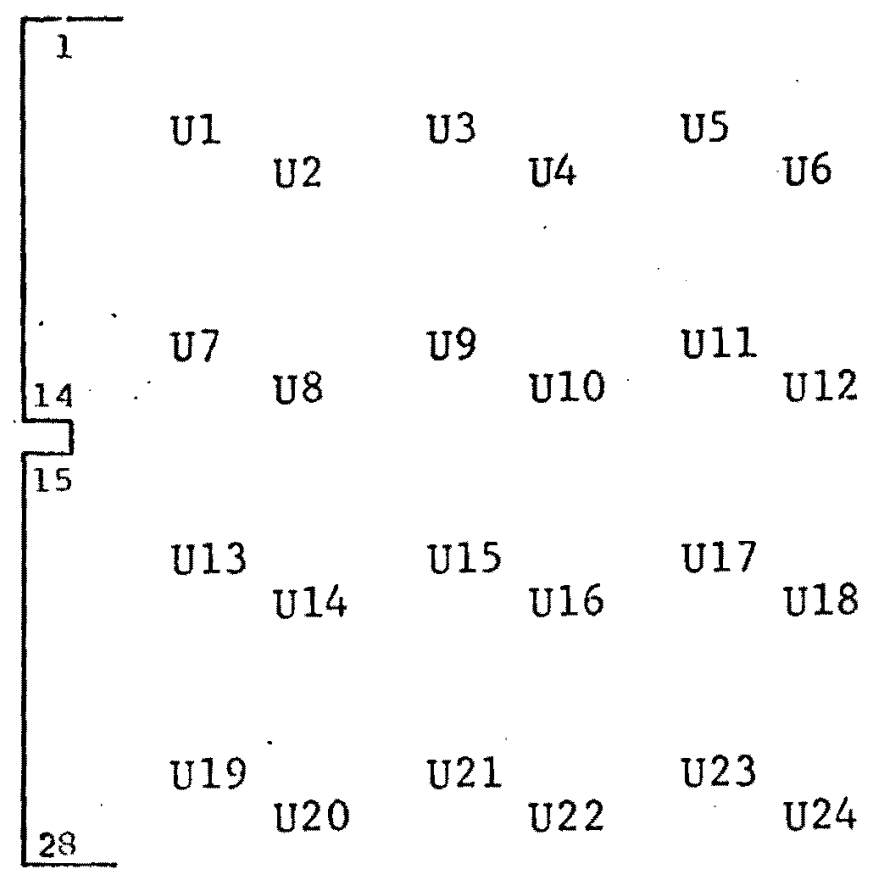


Card H - Memory Interface

Conn. Signal Pin Ckt. Ckt. Pin Signal Conn.

F-11 UNAD-1 A in U5 U5 in 1 LDAD-1 G-11

F-L UNAD-2 $B$ in U4

$\mathrm{U} 4$ in 2 LDAD-2 $\mathrm{G}-\mathrm{L}$

$\mathrm{F}-\mathrm{J} \quad \mathrm{UNAD}-3 \quad \mathrm{C}$ in U3

$\mathrm{F}-18$ UNAD $-4 \quad \mathrm{D}$ in $\mathrm{U} 2$

U3. in 3 LDAD-3 G-J

$\mathrm{F}-\mathrm{U} \quad \mathrm{UNAD}-5 \quad \mathrm{E}$ in $\mathrm{U} 1$

$\mathrm{F}-\mathrm{S}$ UNAD-6 $\mathrm{F}$ in U1

$\mathrm{F}-25$ UNAD $-7 \quad \mathrm{H}$ in $\mathrm{U} 2$

$\mathrm{F}-\mathrm{BB}$ UNAD-8 $\mathrm{J}$ in $\mathrm{U} 3$

$\mathrm{F}-\mathrm{Z}$ UNAD-9 $\mathrm{K}$ in U4

D-E,B-T CYCONP $L$ out U5

$I-11$ CORE-1 $M$ in $U 6$

$\mathrm{I}-12$ CORE-2 $\mathrm{N}$ in $\mathrm{U} 7$

$\mathrm{I}-13$ CORE-3 $\mathrm{P}$ in U8

I-14 CORE-4 $R$ in U9

$\mathrm{U} 2$ in

LDAD $-4 \quad G-18$

$\mathrm{U} 1$ in 5 LDAD-5 G-U

U1 in 6 LDAD-6 G-S

U2 in 7 LDAD-7 G-25

U3 in 8 LDAD-8 G-BB

$\mathrm{U} 4$ in 9 LDAD-9 $\mathrm{G}-\mathrm{Z}$

U5. out 10 CYCOMP $D-F$

$\mathrm{U} 6$ in 11 n.c.

U7 in 12

n.c.

U8 in 13

n.c.

U9 in 14

n.c.

$\begin{array}{llllllllll}\text { I-15 } & \text { CORE-5 } & \text { S } & \text { in } & \text { U11 } & \text { U11 in } & 15 & & \text { n.c. } \\ \text { I-16 } & \text { CORE-6 } & \text { T } & \text { in } & \text { U12 } & \text { U12 in } & 16 & & \text { n.c. } \\ \text { I-17 } & \text { CORE-7 } & \text { U } & \text { in } & \text { U13 } & \text { U13 in } & 17 & & \text { n.c. } \\ \text { I-18 } & \text { CORE-8 } & \text { V } & \text { in U14 } & \text { U14 in } & 18 & & \text { n.c. } \\ \text { n.c. } & & \text { W } & \text { out U23 } & \text { U10 in } & 19 & \text { UNLOAD } & \text { B-S } \\ \text { n.c. } & & X & \text { out U22 } & \text { U15 in } & 20 & \text { LOAD } & \text { D-11 } \\ \text { n.c. } & & \text { Y } & \text { out U16 } & \text { U16 out } & 21 & \text { MEM-1 } & \text { E-W } \\ \text { n.c. } & & \text { Z } & \text { out U17 } & \text { U17 out } & 22 & \text { MEM-2 } & \text { E-X } \\ \text { n.c. } & & \text { AA } & \text { out U18 } & \text { U18 out } & 23 & \text { MEM-3 } & \text { E-Y } \\ \text { n.c. } & & \text { BB } & \text { out U19 } & \text { U19 out } & 24 & \text { MEM-4 } & \text { E-Z } \\ \text { n.c. } & & \text { CC } & \text { out U20 } & \text { U20 out } & 25 & \text { MEM-5 } & \text { E-AA } \\ \text { n.c. } & & \text { DD } & \text { out U21 } & \text { U21 out } & 26 & \text { MEM-6 } & \text { E-BB } \\ +3.6 \mathrm{~V} & & \text { EE } & & & \text { U22 out } & 27 & \text { MEM-7 } & \text { E-CC } \\ \text { GND } & & \text { FF } & & & \text { U23 out } & 28 & \text { MEM-8 } & \text { E-DD }\end{array}$

\begin{tabular}{|c|c|c|c|c|c|}
\hline 1 & U1 & U2 & U3 & $\mathrm{U} 4$ & U5 \\
\hline & U6 & U7 & U8 & U9 & $\mathrm{U} 10$ \\
\hline$\square$ & U11 & U12 & U13 & U14 & U15 \\
\hline & U16 & U17 & U18 & U19 & \\
\hline & U20 & U21 & U22 & U23 & \\
\hline
\end{tabular}


Conn. Signal Pin Ckt. Clkt. Pin Signal Conn.

\begin{tabular}{|c|c|c|c|c|}
\hline $\begin{array}{l}J-1 \\
J-2 \\
J-3 \\
J-4 \\
J-5 \\
J-6 \\
J-7 \\
J-8 \\
J-9 \\
J-10 \\
J-11 \\
J-12 \\
J-13 \\
J-14\end{array}$ & $\begin{array}{l}M V-1 \\
M V-2 \\
M V-3 \\
M V-4 \\
M V-5 \\
M V-6 \\
M V-7 \\
M V-8 \\
M V-9 \\
M V-10 \\
M V-11 \\
M V-12 \\
M V-13 \\
M V-14\end{array}$ & $\begin{array}{l}A \\
B \\
C \\
D \\
E \\
F \\
H \\
J \\
K \\
L \\
M \\
N \\
P \\
R\end{array}$ & $\begin{array}{l}\text { in } \\
\text { in } \\
\text { in } \\
\text { in } \\
\text { in } \\
\text { in } \\
\text { in } \\
\text { in } \\
\text { in } \\
\text { in } \\
\text { in } \\
\text { in } \\
\text { in } \\
\text { in }\end{array}$ & $\begin{array}{l}\text { U1 } \\
\text { U2 } \\
\text { U3 } \\
\text { U6 } \\
\text { U7 } \\
\text { U8 } \\
\text { U13 } \\
\text { U12 } \\
\text { U11 } \\
\text { U17 } \\
\text { U16 } \\
\text { U22 } \\
\text { U21 } \\
\text { U27 }\end{array}$ \\
\hline $\begin{array}{l}\mathrm{J}-15 \\
\mathrm{~J}-16 \\
\mathrm{~J}-17 \\
\mathrm{D}-6 \\
\mathrm{D}-7 \\
\mathrm{D}-8 \\
\mathrm{n} \cdot \mathrm{c} . \\
\mathrm{n} \cdot \mathrm{c} \cdot \\
\mathrm{n} \cdot \mathrm{c} \cdot \\
\mathrm{J}-24 \\
\mathrm{n} \cdot \mathrm{c} . \\
\text { n.c. } \\
+3.6 \mathrm{~V} \\
\text { GND }\end{array}$ & $\begin{array}{l}M V-15 \\
M V-16 \\
\frac{M V-17}{C L} \\
\frac{C 2}{C 3}\end{array}$ & $\begin{array}{l}S \\
T \\
U \\
V \\
W \\
X \\
X \\
Y \\
Z \\
A A \\
B B \\
C C C \\
D D \\
E E \\
F F\end{array}$ & $\begin{array}{l}\text { in } \\
\text { in } \\
\text { in } \\
\text { in } \\
\text { in } \\
\text { in }\end{array}$ & $\begin{array}{l}\mathrm{U} 26 \\
\mathrm{U} 32 \\
\mathrm{U} 31 \\
\mathrm{U}^{\prime} \mathrm{s} \\
\mathrm{U}^{\prime} \mathrm{s} \\
\mathrm{U}^{\prime} \mathrm{s}\end{array}$ \\
\hline
\end{tabular}

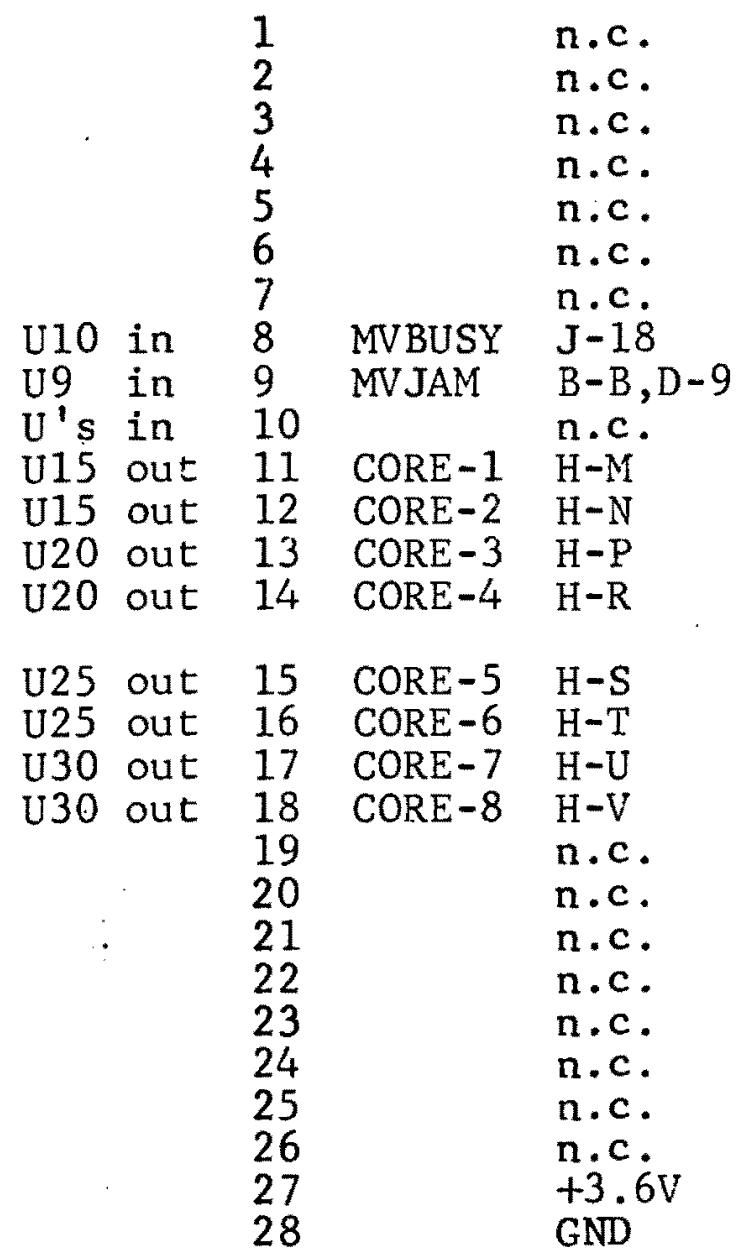

\begin{tabular}{|llllll}
\hline 1 & U1 & U2 & U3 & U4 & U5 \\
& U6 & U7 & U8 & U9 & U10 \\
& U11 & U12 & U13 & U14 & U15 \\
14 & U16 & U17 & U18 & U19 & U20 \\
& U21 & U22 & U23 & U24 & U25 \\
& U26 & U27 & U28 & U29 & U30 \\
& U31 & U32 & U33 & U34 & U35
\end{tabular}


Card J - Multiverter Interface

Conn. Signal Pin $\underline{\text { Ckt. }}$ Ckt. $\underline{\text { Pin }}$ Signal Conn.

n.c.

n.c.

n.c.

n.c.

n.c.

n.c.

n.c.

n.c.

n.c.

n.c.

n.c.

n.c.

n.c.

n.c.

n.c.

n.c.

n.c.

n.c.

n.c.

n.c.

n.c.

n.c.

n.c.

PWR-8

GND

$\mathrm{D}-5$

$+3.6 \mathrm{~V}$

GND

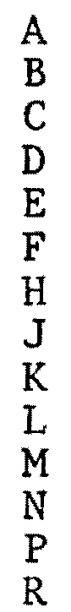

$\mathrm{S}$

$\mathrm{T}$

$\mathrm{U}$

V

W

$\mathrm{X}$

$\mathrm{Y}$

Z

$\mathrm{AA}$

$\mathrm{BB}$

$-12 \mathrm{~V}$
$-12 \mathrm{RTN}$

MVSTRT

$\mathrm{CC}$

$\mathrm{DD}$ in Q5

EE
U3 out 1 MV-1 I-A

U3 out 2 MV-2 I-B

U2. out 3 MV-3 I-C

U2 out 4 MV -4 I-D

U1 out 5 MV -5 I-E

U1 out 6 MV -6 I-F

U6 out 7 MV-7 I-H

U6 out 8 MV-8 $\mathrm{I}-\mathrm{J}$

U5 out 9 MV-9 I-K

U5 out 10 MV-10 I-L

U4 out 11 MV-11 I-M

U4 out 12 MV-12 I-N

U9 out 13 MV-13 I-P

U9 out 14 MV-14 I-R

U8 out 15 MV-15 I-S

U8 out 16 MV-16 I-T

U7 out 17 MV-17 I-U

U7. out 18 MVBUSY $\mathrm{D}-3, \mathrm{I}-8$

Q1 in 19 n.c.

Q3 in 20 n.c.

Q2. in 21 n.c.

Q4 in 22 n.c.

U10 out 24 MVSYNC $\begin{aligned} & \text { n.c. } \\ & 2-4, \mathrm{I}-\mathrm{BB}\end{aligned}$

Q6 in 25 n.c.

n.c.

$+3.6 \mathrm{~V}$

GND

\begin{tabular}{|llll}
\hline & $\mathrm{U} 1$ & $\mathrm{U} 2$ & $\mathrm{U} 3$ \\
& $\mathrm{U} 4$ & $\mathrm{U} 5$ & $\mathrm{U} 6$ \\
& $\mathrm{U} 7$ & $\mathrm{U} 8$ & $\mathrm{U} 9$ \\
14 & & & \\
15 & $\mathrm{Q} 1$ & $\mathrm{Q} 3$ & $\mathrm{U} 10$ \\
& $\mathrm{Q} 2$ & $\mathrm{Q} 4$ & \\
& & $\mathrm{Q}$ & \\
& & $\mathrm{Q} 6$ & \\
& & &
\end{tabular}


Card M - Light Drivers

Conn. Signa1 Pin Ckt. Ckt. Pin Signal Conn.

E-20 TAPE-B $A$ in $Q 1$

E-19 TAPE-A $B$ in Q3

E-18 TAPE-8 $C$ in $Q 2$

E-17 TAPE-4 D in Q4

E-16 TAPE-2 $E$ in $Q 5$

$E-15$ TAPE-1 $F$ in $Q 7$

F-C DPID-9 $\mathrm{H}$ in Q6

$\mathrm{F}-5$ DPID $-\mathrm{A}$ J in $\mathrm{Q} 8$

$\mathrm{F}-\mathrm{A} \quad \mathrm{DPID}-\mathrm{B} \quad \mathrm{K}$ in $\mathrm{Q9}$

$\mathrm{F}-1$ DPID-C $\mathrm{L}$ in Q11

$A-25 \quad R N C-1 \quad M$ in $Q 13$

$A-27 \quad \mathrm{~K} N \mathrm{NC}-2 \quad \mathrm{~N}$ in Q10

$A-B B \quad R N C-3 \quad P$ in $Q 12$

$A-26 \quad \mathrm{RNC}-4 \quad \mathrm{R}$ in $\mathrm{Q} 14$

A-2 RNC-5 $S$ in Q15

$A-22 \quad R N C-6 \quad T$ in 017

G-A DPID-5 U in Q19

G-1 DPID-6 $V$ in Q16

F-4 DPID -7 $W$ in Q18

$F-F \quad D P I D-8 \quad X$ in $Q 20$

B-15 WRIT'G $Y$ in Q21

$C-P$ DATAG $Z$ in $Q 23$

G-4 DPID-1 AA in Q25

$G \cdot F \quad D P I D-2$ BD in Q22

$G-C$ DPID $-3 \quad C$ in $Q 24$

Q1 out 1 DATA-B FPL-10

Q3 out 2 DATA-A FPL-9

Q2. out 3 DATA-8 FPL-8

Q4 out 4 DATA-4 FPL-7

Q5 out 5 DATA-2 FPL-6

Q7 out 6 DATA-1 FPL-5

Q5 out 7 BYTI-1 FPL-4

Q8 out 8 BYTI-2 FPL-3

Q9 out 9 BYT1-4 FPL-2

Q11 out 10 BYT1-8 FPL-1

Q13 out 11 RECL-1 FPL-20

Q10 out 12 RECL-2 FPL-19

Q12 out 13 RECL-4 FPL-13

Q14 out 14 RECL-8 FPL-17

G-5

$\mathrm{DD}$ in Q26

Q15 out 15 RECL-16 FPL-16

Q17 out 16 RECL-32 FPL-15

Q19 out 17 BYT2-1 FPL-14

Q16 cut 18 BYT2-2 FPL-13

Q18 out 19 BYT2-4 FPL-12

Q20 out 20 BYT2-8 FPL-11

Q21 out 21 WRITEL FPI-26

Q23 out 22 GATEDL FPL-25

Q25 out 23 BYT3-1 FPL-24

Q22 out 24 BYT3-2 FPL-23

Q24 out 25 BYT3-4 FPL-22

Q26 out 26 BYT3-8 FPL-21

n.c. $E E$

27

n.c.

GND $+8.5 \mathrm{RTN}$ FF emitters of all Q's $28+8.5 \mathrm{RTN}$ GND

\begin{tabular}{|c|c|c|c|}
\hline \multirow[t]{2}{*}{1} & $\begin{array}{l}\mathrm{Q} 1 \\
\mathrm{Q} 2\end{array}$ & $\begin{array}{l}\text { Q3 } \\
\text { Q4 }\end{array}$ & \\
\hline & $\begin{array}{l}\mathrm{Q} 5 \\
\mathrm{Q} 6\end{array}$ & $\begin{array}{l}\text { Q7 } \\
\text { Q8 }\end{array}$ & \\
\hline \multirow[t]{2}{*}{$\frac{124}{15}$} & $\begin{array}{l}\text { Q9 } \\
\text { Q10 }\end{array}$ & $\begin{array}{l}\text { Q11 } \\
\text { Q12 }\end{array}$ & $\begin{array}{l}\text { Q13 } \\
\text { Q14 }\end{array}$ \\
\hline & $\begin{array}{l}\text { Q15 } \\
\text { Q16 }\end{array}$ & $\begin{array}{l}\text { Q17 } \\
\text { Q18 }\end{array}$ & $\begin{array}{l}\text { Q19 } \\
\text { Q20 }\end{array}$ \\
\hline 28 & $\begin{array}{l}\text { Q21 } \\
\text { Q22 }\end{array}$ & $\begin{array}{l}\text { Q23 } \\
\text { Q24 }\end{array}$ & $\begin{array}{l}\text { Q25 } \\
\text { Q26 }\end{array}$ \\
\hline
\end{tabular}


Conn. Signal Pin Ckt. Ckt. Pin Signal Conn.

N-14 TPERFF A in Q1

$\mathrm{N}-15$ PARFF $\mathrm{B}$ in $\mathrm{Q} 3$

Q1 out 1 TPERL FPL-30

$\mathrm{N}-13$

ECHFF

$\mathrm{C}$ in $\mathrm{O} 2$

Q3 out 2

PARERL FPL-29

$\mathrm{N}-16$

SYNCFF

$D$ in 04

Q2 out 3

$S-B B$

SPROFF

$\mathrm{E}$ in $\mathrm{U} 1, \mathrm{U} 2$

Q4 out 4

ECHERL FPL-28

$\mathrm{S}-\mathrm{AA}$

WMODE

$\mathrm{F}$ in $\mathrm{U} 1$

Q5 out 5

SYNERL FPL-27

$\mathrm{J}-24$

MVSYNC

$\mathrm{H}$ in $\mathrm{Q} 6$

Q7 out 6

RUNL

FPL -32

n.c.

Spare

$\mathrm{J}$ in $\mathrm{Q} 8$

n.c.

Li.ght

$\mathrm{K}$ in $\mathrm{Q} 9$

Q6 out 7

READYL FPL-31

Q8 out 8

ESYNCL FPL-33

Q9 out 9

n.c.

Drivers

in Q11

n.c.

$M$ in $Q 10$

n.c.

" $\mathrm{N}$ in $\mathrm{Q} 12$

S-22 ECOERR $P$ in U6

S-17 XPTERR $R$ in U5

Q11 out 10

n.c.

Q10 out 11

Q12 out 12

Q6 out 13

U5 out 14 TPERFF $\mathrm{N}-\mathrm{A}$

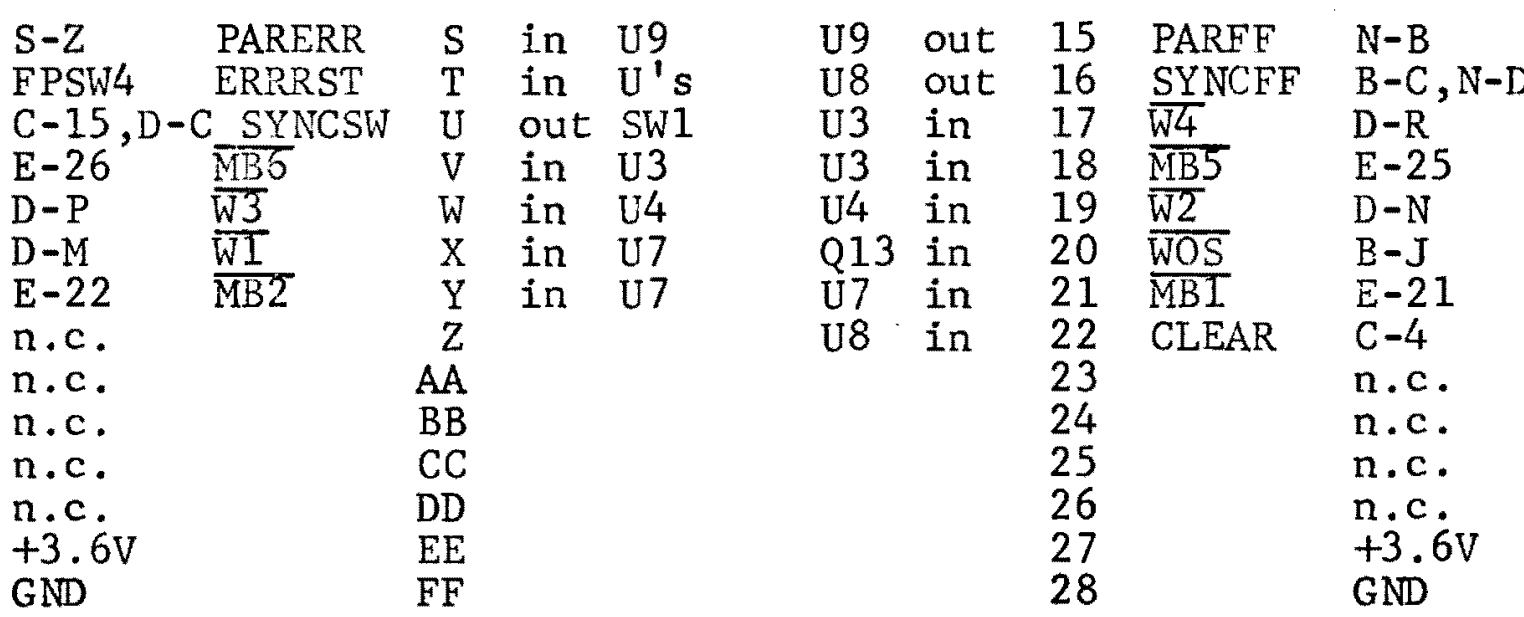

\begin{tabular}{|c|c|c|c|}
\hline $\begin{array}{l}\text { Q1 } \\
\text { Q2 }\end{array}$ & U1 & $\begin{array}{l}\text { Q3 } \\
\text { Q4 }\end{array}$ & TP1 TP2 \\
\hline $\begin{array}{l}\text { Q5 } \\
Q 6\end{array}$ & U2 & $\begin{array}{l}\text { Q7 } \\
\text { Q8 }\end{array}$ & \\
\hline $\begin{array}{l}\text { Q9 } \\
\text { Q10 }\end{array}$ & & $\begin{array}{l}\text { Q11 } \\
\text { Q12 }\end{array}$ & \\
\hline U3 & U4 & U5 & U6 \\
\hline U7 & Q13 & U8 & U9 \\
\hline
\end{tabular}


Card S - Tape Recorder Interface

Conn. Signal Pin Ckt. Ckt. Pin Signal Conn.

n.c.

n.c.

n.c.

$+3.6 \mathrm{~V}$

n.c.

n.c.

n.c.

n.c.

n.c.

n.c.

n.c.

n.c.

n.c.

n.c.

n.c.

n.c.

n.c.

n.c.

n.c.

n.c.

n.c.

$\mathrm{N}-\mathrm{S}$

$\mathrm{C}-3, \mathrm{~N}-\mathrm{F}$

n.c.

$\mathrm{B}-8$

$+3.6 \mathrm{~V}$

GND

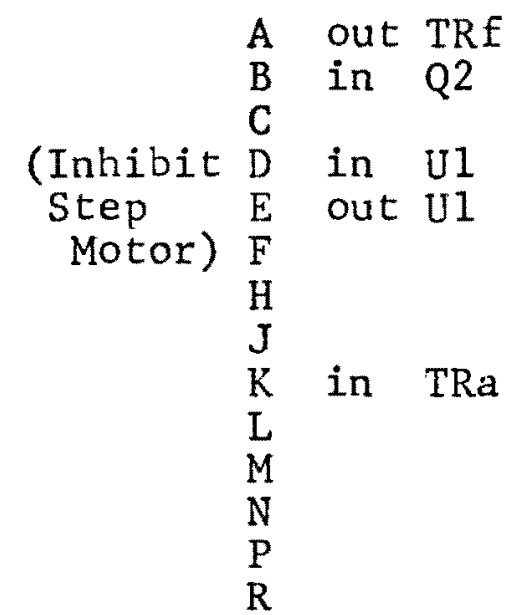

$\mathrm{S}$

$\mathrm{T}$

$\mathrm{U}$

$\mathrm{V}$

W

$\mathrm{X}$ out U15

$Y$ out TRg

PARERR $Z$ out U12

WMODE AA out U13

SPROFF

$\mathrm{BB}$ out U14

CC out U14

WRITE

$\mathrm{DD}$ in Q13

EE

FF
Q4 in 2 TAPE-B $\begin{array}{ll}1 & \mathrm{n} \cdot \mathrm{c} \text {. } \\ 2 & \mathrm{O}\end{array}$

Q5 in 3 TAPE-A E-19

Q6 in 4 TAPE-8 E-18

Q7 in 5 TAPE-4 E-17

Q8 in 6 TAPE-2 $\mathrm{E}-16$

Q9 in 7 TAPE-1 E-15

Q3 in 8 LCCSET $A-X$

9 n.c.

10 n.c.

11 n.c.

12 n.c.

13 n.c.

14 n.c.

U7 out 15 n.c.

16 n.c.

D's out 17 XPTERR N-R

18 n.c.

U15 19 n.c.

U15 out 20 n.c.

TRA in 21 n.c.

U12 out 22 ECOERR N-P

U13 out 23 n.c.

Q12 in 24 FORWRD $\mathrm{C}-\mathrm{C}$

U17 in 25 n.c.

U17 in 26 n.c.

$+3.6 \mathrm{~V}$

GND

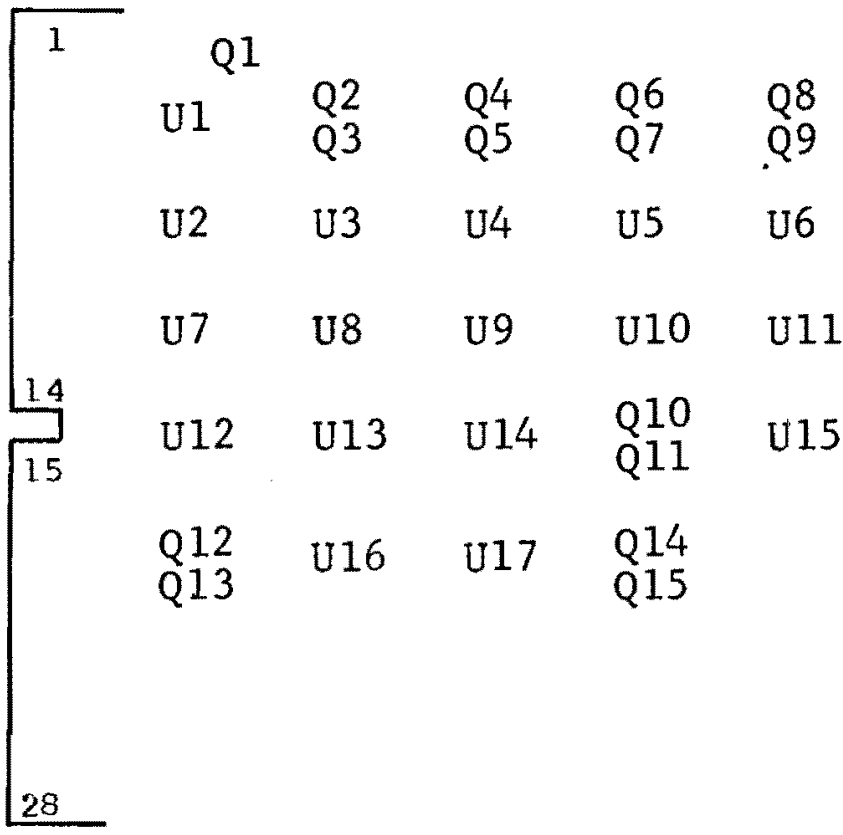


FP - Front Pane1 Lights and Switches

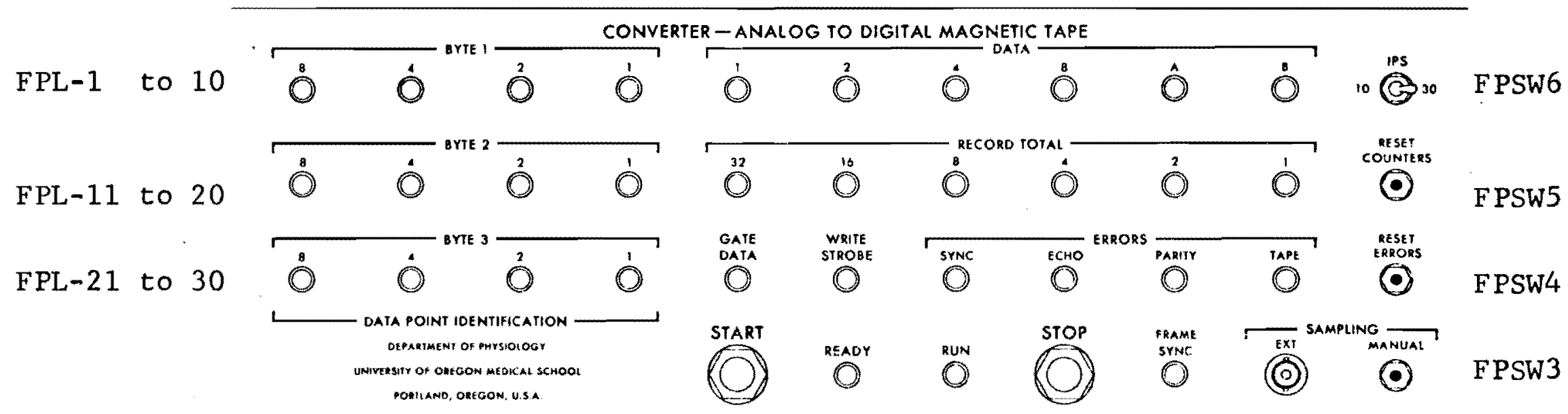

(FPSW7, 8,9,10 behind pane1) FPSW1 FPL-31 FPL-32 FPSW2 FPL-33 FPBNC

$\begin{array}{lll}\text { FPL-1 } & \text { BYT 1-8 } & M-10 \\ \text { FPL-2 } & \text { BYT 1-4 } & M-9 \\ \text { FPL-3 } & \text { BYT 1-2 } & M-8 \\ \text { FPL-4 } & \text { BYT 1-1 } & M-7 \\ \text { FPL-5 } & \text { DATA-1 } & M-6 \\ \text { FPL-6 } & \text { DATA-2 } & M-5 \\ \text { FPL-7 } & \text { DATA-4 } & M-4 \\ \text { FPL-8 } & \text { DATA-8 } & M-3 \\ \text { FPL-9 } & \text { DATA-A } & M-2 \\ \text { FPL-10 } & \text { DATA-B } & M-1 \\ \text { FPL-11 } & \text { BYT2-8 } & M-20 \\ \text { FPL-12 } & \text { BYT2-4 } & M-19 \\ \text { FPL-13 } & \text { BYT2-2 } & M-18 \\ \text { FPL-14 } & \text { BYT2-1 } & M-17 \\ \text { FPL-15 } & \text { RECL-32 } & M-16 \\ \text { FPL-16 } & \text { RECL-16 } & M-15 \\ \text { FPL-17 } & \text { RECL-8 } & M-14\end{array}$

$\begin{array}{lll}\text { FPL-18 } & \text { RECL-4 } & M-11 \\ \text { FPL-19 } & \text { RECL-2 } & M-12 \\ \text { FPL-20 } & \text { RECL-1 } & M-13 \\ \text { FPL-21 } & \text { BYT3-8 } & M-26 \\ \text { FPL-22 } & \text { BYT3-4 } & \mathrm{M}-25 \\ \text { FPL-23 } & \text { BYT3-2 } & \mathrm{M}-24 \\ \text { FPL-24 } & \text { BYT3-1 } & \mathrm{M}-23 \\ \text { FPL-25 } & \text { GATEDL } & \mathrm{M}-22 \\ \text { FPL-26 } & \text { WRTTEL } & \mathrm{M}-21 \\ \text { FPL-27 } & \text { SYNERL } & \mathrm{N}-4 \\ \text { FPL-28 } & \text { ECHERL } & \mathrm{N}-3 \\ \text { FPL-29 } & \text { PARERL } & \mathrm{N}-2 \\ \text { FPL-30 } & \text { TPERL } & \mathrm{N}-1 \\ \text { FPL-31 } & \text { READYL } & \mathrm{N}-6 \\ \text { FPL-32 } & \text { RUNL } & \mathrm{N}-5 \\ \text { FPL-33 } & \text { FSYNCL } & \mathrm{N}-7 \\ & & \end{array}$

FPSW1 START $\mathrm{C}-6 \quad$ FPSW7

FPSW2 STOP $\mathrm{C}-7$ :

1: RLC-U1 A-4

FPSW3

out: MPBNC $\mathrm{C}-14 \quad 4$ : RLC-E4 A-1

in: MPBNO C-R 2: RLC-E2 A-A

FPSW4 ERRRST N-T FPSW 9 RLC-E1 A-5

FPSW5 RSTPB $\mathrm{C}-1$ : RLC-S4 A-L

FPSW6 FPSW10 RLC-S1 A-11

10: SLOW A-T, 4: RLC-F4 A-8

30. FAST $\mathrm{C}-\mathrm{U} \quad 2:$ RLC-F2 $A-J$

A-S, $\quad 1:$ RLC-F1 A-12

$\begin{array}{lll}\text { FPL-16 } & \text { RECL-16 } & \text { M-15 } \\ \text { FPL-17 } & \text { RECL-8 } & \text { M-14 }\end{array}$ $\mathrm{C}-17$

FPSW's RLCRST

$A-20 \omega$ 
ADPISIX III

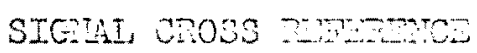




\begin{tabular}{|c|c|c|c|c|c|}
\hline SOURCE & SIGNAL & DESTINATION & SOURCE & SIGNAL & DESTINATION \\
\hline $\mathrm{D}-\mathrm{H}$ & $\bar{A}$ & $E-7$ & $\begin{array}{l}M-3 \\
M-2\end{array}$ & $\begin{array}{l}\text { DATA-8 } \\
\text { DATA-A }\end{array}$ & $\begin{array}{l}\text { Ken-L, F PL-8 } \\
\text { Ken-M, F PL-9 }\end{array}$ \\
\hline$D-J$ & $\overline{\mathrm{B}}$ & $E-8$ & $\mathrm{M}-1$ & DATA-B & Ken-N,FPL-10 \\
\hline $\begin{array}{r}\text { MVRTR } \\
1-17\end{array}$ & $\begin{array}{l}\text { BIT1- } \\
\text { BIT17 }\end{array}$ & Card J & $\begin{array}{l}C-P \\
D-B\end{array}$ & $\frac{\text { DATAG }}{\text { DIRECT }}$ & $\begin{array}{l}M-Z \\
B-4\end{array}$ \\
\hline Ken-Z & $\mathrm{BOT}$ & Card S & $G-1$ & DPCARY & $F-D$ \\
\hline Ken-a & $\begin{array}{l}\text { Broken } \\
\text { Tape }\end{array}$ & Card S & $\begin{array}{l}G-4 \\
G-F\end{array}$ & $\begin{array}{l}\text { DPID - } 1 \\
\text { DPID - }\end{array}$ & $\begin{array}{l}E-A, M-A A \\
E-B, M-B B\end{array}$ \\
\hline$M V-18$ & BUSY & Card J & $G-C$ & DPID - 3 & $E-C, M-C C$ \\
\hline$M-7$ & BYI1-1 & FPL-4 & $G-5$ & DPID -4 & $E-D, M-D D$ \\
\hline$M-8$ & BYTI-2 & FPL-3 & $G-A$ & DPID - 5 & $E-E, M-U$ \\
\hline$M-9$ & BYT1-4 & FPL-2 & $G-1$ & DPID - 6 & $E-F, M-V$ \\
\hline$M-10$ & BYT1-8 & FPL-1 & $F-4$ & DPID -7 & $E-H, M-W$ \\
\hline$M-17$ & BYT2 - 1 & FPL-14 & $F-F$ & DPID - 8 & $E-J, M-X$ \\
\hline$M-18$ & BYT2 - 2 & FPL -13 & $F-C$ & DPID -9 & $\mathrm{E}-\mathrm{K}, \mathrm{M}-\mathrm{H}$ \\
\hline$M-19$ & BYT 2-4 & FPL-12 & $F-5$ & DPID-A & $E-L, M-J$ \\
\hline$M-20$ & BYT2-8 & FPL-11 & $F-A$ & DPID-B & $\mathrm{E}-\mathrm{M}, \mathrm{M}-\mathrm{K}$ \\
\hline$M-23$ & BYT 3-1 & FPL-24 & $F-1$ & DPID-C & $E-N, M-L$ \\
\hline$M-24$ & BYT 3-2 & FPL-23 & $\mathrm{C}-\mathrm{T}$ & DSAMPL & $D-2$ \\
\hline$M-25$ & BYT $3-4$ & FPL -22 & & & \\
\hline$M-26$ & BYI $3-8$ & FPL-21 & $N-3$ & ECHERL & FPL-28 \\
\hline$B-3$ & BYTRST & $D-10, G-D$ & $\begin{array}{l}\mathrm{N}-13 \\
\text { Ken }-\mathrm{P}\end{array}$ & $\begin{array}{l}\text { ECHFF } \\
\text { ECHO-1 }\end{array}$ & $\begin{array}{l}\mathrm{N}-\mathrm{C} \\
\text { Card } \mathrm{S}\end{array}$ \\
\hline$D-L$ & C & $B-K$ & Ken-R & $\mathrm{ECHO}-2$ & Card S \\
\hline $\mathrm{D}-\mathrm{K}$ & $\overline{\mathrm{C}}$ & $E-9$ & Ken-S & $\mathrm{ECHO}-\overline{\mathrm{Y}}$ & Card $\mathrm{S}$ \\
\hline$D-6$ & $\overline{\mathrm{CI}}$ & $I-V$ & Ken-T & $\mathrm{ECHO}-8$ & Card S \\
\hline$D-7$ & $\overline{\mathrm{C} 2}$ & $I-W$ & Ken-U & ECHO-A & Card S \\
\hline$D-8$ & $\overline{\mathrm{C} 3}$ & $I-X$ & Ken-V & ECHO-B & Card S \\
\hline$C-4$ & CLEAR & $\mathrm{B}-1, \mathrm{~N}-22$ & Ken-W & $\mathrm{ECHO}-\mathrm{W}$ & Card S \\
\hline$C-E$ & CLEAR & $D-15$ & $S-22$ & ECOERR & $\mathrm{N}-\mathrm{P}$ \\
\hline$C-\bar{V}$ & $\overline{\mathrm{CLOCK}}$ & $B-M, D-1$ & Ken-Y & EOT & Card S \\
\hline$C-19$ & CLOCK & $B-11, D-S$ & FPSW4 & ERRRST & $\mathrm{N}-\mathrm{T}$ \\
\hline$C-D$ & CLREND & $A-6$ & & & \\
\hline EPBNC & COAX & $C-F$ & FPSW6 & FAST & $A-S, C-17$ \\
\hline$B-7$ & COINC & $C-8$ & Ken-B & FILEGAP & \\
\hline $\mathrm{I}-11$ & CORE-1 & $\mathrm{H}-\mathrm{M}$ & $E-10$ & FILLER & $B-F$ \\
\hline$I-12$ & CORE-2 & $\mathrm{H}-\mathrm{N}$ & $B-12$ & FORCE & $E-V$ \\
\hline$I-13$ & CO?E-3 & $\mathrm{H}-\mathrm{P}$ & Ken-F & FORWARD & \\
\hline$I-14$ & $C O \geq E-4$ & $\mathrm{H}-\mathrm{R}$ & $C-B$ & FORWRD & $\mathrm{B}-\mathrm{H}$ \\
\hline$I-15$ & CORE-5 & $\mathrm{H}-\mathrm{S}$ & $C-C$ & FORWRD & $S-24$ \\
\hline$I-16$ & CORE-6 & $\mathrm{H}-\mathrm{T}$ & $M V-45$ & FRAME1 & \\
\hline $\mathrm{I}-17$ & CORE-7 & $\mathrm{H}-\mathrm{U}$ & $N-7$ & ESYNCL & FPL-33 \\
\hline $\mathrm{T}-18$ & CORE- 8 & $\mathrm{H}-\mathrm{V}$ & & & \\
\hline $\mathrm{H}-\mathrm{L}$ & CYCOMP & $B-T, D-E$ & $M-22$ & GATEDL & FPL-25 \\
\hline $\mathrm{H}-10$ & CYCOMP & $D-F$ & & TNDTPC & $B-T$ \\
\hline$M-6$ & DATA-1 & Ken-H, FPL-5 & $D-23$ & INDIRC & $B-10$ \\
\hline$M-5$ & DATA-2 & Ken-J,FPL-6 & Ken-A & IRG & Card S \\
\hline$M-4$ & DATA-4 & Ken-K,FPL-7 & $A-15$ & IRGAP & $\mathrm{B}-\mathrm{P}$ \\
\hline
\end{tabular}


SOURCE SIGNAL DESTINATION

$\begin{array}{lll}\text { A-Y } & \text { IRGAP } & \text { C-10, B-13 } \\ \text { A-W } & \text { LCCGAP } & \text { C-H } \\ \text { A-X } & \text { LCCSET } & \text { S-8 } \\ \text { G-11 } & \text { LDAD-1 } & \text { H-1 } \\ \text { G-L } & \text { LDAD-2 } & \text { H-2 } \\ \text { G-J } & \text { LDAD-3 } & \text { H-3 } \\ \text { G-18 } & \text { LDAD-4 } & \text { H-4 } \\ \text { G-U } & \text { LDAD-5 } & \text { H-5 } \\ \text { G-S } & \text { LDAD-6 } & \text { H-6 } \\ \text { G-25 } & \text { LDAD-7 } & \text { H-7 } \\ \text { G-BB } & \text { LDAD-8 } & \text { H-8 } \\ \text { G-Z } & \text { LDAD-9 } & \text { H-9 } \\ \text { B-17 } & \text { LDCLK } & \text { G-I } \\ \text { G-P } & \text { LDCO-1 } & \text { B-V } \\ \text { G-12 } & \text { LDCO-2 } & \text { B-W } \\ \text { G-13 } & \text { LDCO-3 } & \text { B-X } \\ \text { G-X } & \text { LDCO-4 } & \text { B-Y } \\ \text { G-19 } & \text { LDCO-5 } & \text { B-Z } \\ \text { G-20 } & \text { LDCO-6 } & \text { B-AA } \\ \text { G-EE } & \text { LDCO-7 } & \text { B-BB } \\ \text { G-26 } & \text { LDCO-8 } & \text { B-CC } \\ \text { G-27 } & \text { LDCO-9 } & \text { B-DD } \\ \text { G-8 } & \text { LDCY-3 } & \text { G-V } \\ \text { G-19 } & \text { LDCY-6 } & \text { G-CC } \\ \text { D-11 } & \text { LOAD } & \text { B-16, H-20 } \\ \text { D-12 } & \text { LOAD G } & \text { B-R, B-2 } \\ \text { D-13 } & \text { LOAD 'G } & \text { B-14 } \\ \text { MV-28 } & \text { LOGIC RETURN Card } \\ \text { MV-27 } & \text { LOGIC VOLTAGE J } \\ \text { L } & & \end{array}$

$\begin{array}{lll}\text { E-21 } & \text { MB1 } & \text { N-21 } \\ E-22 & \text { MB2 } & \text { N-Y } \\ \text { E-25 } & \text { MB5 } & \text { N-18 } \\ \text { E-26 } & \text { MB6 } & \text { N-V } \\ \text { H-21 } & \text { MEM-1 } & \text { E-W } \\ \text { H-22 } & \text { MEM-2 } & \text { E-X } \\ \text { H-23 } & \text { MEM-3 } & \text { E-Y } \\ \text { H-24 } & \text { MEM-4 } & \text { E-Z } \\ \text { H-25 } & \text { MEM-5 } & \text { E-AA } \\ \text { H-26 } & \text { MEM-6 } & \text { E-BB } \\ \text { H-27 } & \text { MEM-7 } & \text { E-CC } \\ \text { H-28 } & \text { MEM-8 } & \text { E-DD } \\ \text { MV-46 } & \text { MODLSB } & \text { Card J } \\ \text { MV-47 } & \text { MODMSB } & \text { Card J } \\ \text { FPSW3 } & \text { MPBNC } & \text { C-14 } \\ \text { FPSW3 } & \text { MPBNO } & \text { C-R } \\ \text { MV-41 } & \text { MPX5SB } & \text { Card J } \\ \text { MV-42 } & \text { MPX6SB } & \text { Card J }\end{array}$

SOURCE SIGNAL DESTINATION

\begin{tabular}{|c|c|c|}
\hline $\begin{array}{l}M V-43 \\
M V-44 \\
J-1 \\
J-2 \\
J-3 \\
J-4 \\
J-5 \\
J-6 \\
J-7 \\
J-8 \\
J-9 \\
J-10 \\
J-11 \\
J-12 \\
J-13 \\
J-14 \\
J-15 \\
J-16 \\
J-17 \\
J-18 \\
I-9 \\
D-5 \\
J-24\end{array}$ & $\begin{array}{l}\text { MPX7SB } \\
\text { MPXLSB } \\
\text { MV -1 } \\
\text { MV-2 } \\
\text { MV-3 } \\
\text { MV-4 } \\
\text { MV-5 } \\
\text { MV-6 } \\
\text { MV-7 } \\
\text { MV-8 } \\
\text { MV-9 } \\
\text { MV-10 } \\
\text { MV -11 } \\
\text { MV-12 } \\
\text { MV-13 } \\
\text { MV-14 } \\
\text { MV-15 } \\
\text { MV-16 } \\
\text { MV-17 } \\
\text { MVBUSY } \\
\text { MVJAM } \\
\text { MVSTRT } \\
\text { MVSYNC }\end{array}$ & $\begin{array}{l}\text { Card J } \\
\text { Card } \mathrm{J} \\
\text { I-A } \\
\text { I-B } \\
\text { I-C } \\
\text { I-D } \\
\text { I-E } \\
\text { I-F } \\
\text { I-H } \\
\text { I-J } \\
\text { I-K } \\
\text { I-L } \\
\text { I-M } \\
\text { I-N } \\
\text { I-P } \\
\text { I-R } \\
\text { I-S } \\
\text { I-T } \\
\text { I-U } \\
\text { D-3,I-8 } \\
\text { B-B,D-9 } \\
\text { J-DD } \\
\text { D-4,I-BB , N-H }\end{array}$ \\
\hline $\begin{array}{l}B-E \\
B-5\end{array}$ & $\begin{array}{l}\text { NOLOAD } \\
\text { NOUNLD }\end{array}$ & $\begin{array}{l}\mathrm{G}-7, \mathrm{G}-28, \mathrm{G}-21 \\
\mathrm{~F}-7, \mathrm{~F}-28, \mathrm{~F}-21\end{array}$ \\
\hline $\begin{array}{l}A-17 \\
A-14\end{array}$ & $\begin{array}{l}\text { OVFLOS } \\
\text { OVFLOW }\end{array}$ & $\begin{array}{l}A-C C \\
A-V\end{array}$ \\
\hline
\end{tabular}

N-2 PARERL FPL-29

$\mathrm{S}-\mathrm{Z}$ PARERR N-S

N-15 PARFF N-B

Ken-X PARITY Card S CHECK

Ken-d PARITY Card $S$

GEN

C-N PRESET A-16

Ken-K PWRGND Card S

N-6 READYL FPL-31

M-11 RECL-1 FPL-20

M-12 RECL-2 FPL-19

M-13 RECL-4 FPL-18

M-14 RECL-8 FPL-17

M-15 RECL-16 FPL-16

M-16 RECL-32 FPL=15

Ken-b REMOTE READ Card

Ken-k REMOTE WRITE S 
SOURCE SIGNAL DESTINATION SOURCE SIGNAL DESTINATION

\begin{tabular}{|c|c|c|c|c|c|}
\hline $\begin{array}{l}\text { Ken-E } \\
\text { C-12 } \\
C-13\end{array}$ & $\begin{array}{l}\text { RESET } \\
\text { RESET1 } \\
\text { RESET2 }\end{array}$ & $\begin{array}{l}\text { Card S } \\
A-24, H, 3,10 \\
F-3,6,10,17,24 \\
G-3,6,10,17,24\end{array}$ & $\begin{array}{l}E-19 \\
E-20 \\
N-14 \\
N-1\end{array}$ & $\begin{array}{l}\text { TAPE-A } \\
\text { TAPE-B } \\
\text { TPERFF } \\
\text { TPERL }\end{array}$ & $\begin{array}{l}S-3, M-B \\
S-2, M-A \\
N-A \\
\text { FPL }-30\end{array}$ \\
\hline $\begin{array}{l}\text { A-1 } \\
\text { FPSW8 } \\
\text { FPSW8 } \\
\text { FPSW8 } \\
\text { FPSW10 } \\
\text { FPSW10 } \\
\text { FPSW10 } \\
\text { A-20 } \\
\text { FPSW9 } \\
\text { FPSW9 } \\
\text { FPSW9 } \\
\text { FPSW7 } \\
\text { FPSW7 } \\
\text { FPSW7 } \\
\text { A-25 } \\
\text { A-27 } \\
\text { A-BB } \\
\text { A-26 } \\
\text { A-Z } \\
\text { A-22 } \\
\text { FPSW5 } \\
\text { N-5 }\end{array}$ & $\begin{array}{l}\text { RLCARY } \\
\text { RLC-E1 } \\
\text { RLC-E2 } \\
\text { RLC-E4 } \\
\text { RLC-F1 } \\
\text { RLC-F2 } \\
\text { RLC-F4 } \\
\text { RLCRST } \\
\text { RLC-S1 } \\
\text { RLC-S2 } \\
\text { RLC-S4 } \\
\text { RLC-U1 } \\
\text { RLC-U2 } \\
\text { RLC-U4 } \\
\text { RNC-1 } \\
\text { RNC-2 } \\
\text { RNC-3 } \\
\text { RNC-4 } \\
\text { RNC-5 } \\
\text { RNC-6 } \\
\text { RSTPB } \\
\text { RUNL }\end{array}$ & $\begin{array}{l}A-M \\
A-5 \\
A-A \\
A-1 \\
A-12 \\
A-J \\
A-8 \\
F P S W 7,8,9,10 \\
A-11 \\
A-P \\
A-L \\
A-4 \\
A-F \\
A-C \\
M-M \\
M-N \\
M-P \\
M-R \\
M-S \\
M-T \\
C-1 \\
F P L-32\end{array}$ & $\begin{array}{l}F-11 \\
F-L \\
F-J \\
F-18 \\
F-U \\
F-S \\
F-25 \\
F-B B \\
F-Z \\
B-U \\
F-P \\
F-12 \\
F-13 \\
F-X \\
F-19 \\
F-20 \\
F-E E \\
F-26 \\
F-27 \\
F-8 \\
F-15 \\
B-S\end{array}$ & $\begin{array}{l}\text { UNAD-1 } \\
\text { UNAD-2 } \\
\text { UNAD - } \\
\text { UNAD-4 } \\
\text { UNAD-5 } \\
\text { UNAD-6 } \\
\text { UNAD-7 } \\
\text { UNAD-8 } \\
\text { UNAD-9 } \\
\text { UNCLK } \\
\text { UNCO-1 } \\
\text { UNCO-2 } \\
\text { UNCO-3 } \\
\text { UNCO-4 } \\
\text { UNCO-5 } \\
\text { UNCO-6 } \\
\text { UNCO-7 } \\
\text { UNCO-8 } \\
\text { UNCO-9 } \\
\text { UNCY - - } \\
\text { UNCY -6 } \\
\text { UNLOAD }\end{array}$ & $\begin{array}{l}H-A \\
H-B \\
H-C \\
H-D \\
H-E \\
H-F \\
H-H \\
H-J \\
H-K \\
F-M, E-P \\
B-18 \\
B-19 \\
B-20 \\
B-21 \\
B-22 \\
B-23 \\
B-24 \\
B-25 \\
B-26 \\
F-V \\
F-C C \\
H-19\end{array}$ \\
\hline $\begin{array}{l}\text { B-D } \\
\text { FPSW6 } \\
\text { S-BB } \\
\text { FPSW1 } \\
\text { MV -50 } \\
M V-49\end{array}$ & $\begin{array}{l}\text { SHIFT } \\
\text { SLOW } \\
\text { SPROFF } \\
\text { START } \\
\text { START } \\
\text { START } \\
\text { RETURN }\end{array}$ & $\begin{array}{l}D-T \\
A-T, C-U \\
N-E \\
C-6 \\
\text { Card J } \\
\text { Card J }\end{array}$ & $\begin{array}{l}D-M \\
D-N \\
D-P \\
D-R \\
E-23 \\
E-24\end{array}$ & $\begin{array}{l}\frac{\text { WI }}{W 2} \\
\frac{W 3}{W 4} \\
\text { W4L } \\
\text { W4N }\end{array}$ & $\begin{array}{l}E-11, N-X \\
E-12, N-19 \\
E-13, N-W \\
E-14, N-17 \\
B-6, D-A \\
B-9\end{array}$ \\
\hline $\begin{array}{l}\text { Ken-C } \\
\text { Ken-j }\end{array}$ & $\begin{array}{l}\text { STEP } \\
\text { STEP IN- } \\
\text { HIBIT }\end{array}$ & $\begin{array}{l}\text { Card S } \\
\text { Card } \\
\text { S }\end{array}$ & $\begin{array}{l}S-A A \\
B-J \\
B-N\end{array}$ & $\begin{array}{l}\text { WMODE } \\
\overline{\text { WOS }} \\
\text { WRDRST }\end{array}$ & $\begin{array}{l}\mathrm{C}-3, \mathrm{~N}-\mathrm{F} \\
\mathrm{N}-20 \\
\mathrm{D}-17\end{array}$ \\
\hline Ken-E & $\begin{array}{l}\text { STEP PIN } \\
\text { ROLLER }\end{array}$ & $\mathrm{NCH}$ Card & $\begin{array}{l}B-8 \\
M-21\end{array}$ & $\begin{array}{l}\text { WRITE } \\
\text { WRITEL }\end{array}$ & $\begin{array}{l}\text { S-DD,A-D } \\
\text { F PL-26 }\end{array}$ \\
\hline $\begin{array}{l}\text { FPSW2 } \\
N-16\end{array}$ & $\begin{array}{l}\text { STOP } \\
\text { SYNCEF }\end{array}$ & $\begin{array}{l}C-7 \\
B-C, N-D\end{array}$ & B-15 & WRIT 'G & $M-Y$ \\
\hline $\begin{array}{l}N-U \\
N-4\end{array}$ & $\begin{array}{l}\text { SYNCSW } \\
\text { SYNERL }\end{array}$ & $\begin{array}{l}C-15, D-C \\
\text { FPL }-27\end{array}$ & $3-16$ & XFIEKK & $N-K$ \\
\hline $\begin{array}{l}E-15 \\
E-16 \\
E-17 \\
E-18\end{array}$ & $\begin{array}{l}\text { TAPE }-1 \\
\text { TAPE- } \\
\text { TAPE }-4 \\
\text { TAPE }-8\end{array}$ & $\begin{array}{l}S-7, M-F \\
S-6, M-E \\
S-5, M-D \\
S-4, M-C\end{array}$ & & & \\
\hline
\end{tabular}


ATP DI: IV

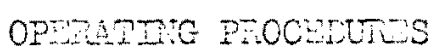


I. EQUIPNENT LOCATION AND ABBREVIATIONS:

The Analog to Digital Data Conversion System is located in a single electronics rack organized from top to bottom as follows:

1) Kennedy Tape Recorder Transport $=T R$

2) Kennedy Read Electronics Cage = RC

3) 1130 Interface Electronics = IF

4) Converter System Controlier = $\mathrm{CV}$

5) Buffer Menory = $\mathrm{BM}$

6) Multiverter $A / D$ Converter = MV

7) Analog Input Pane1 = AP

8) Power Supply = PS

II. PRELIMINARY SWITCH SETTINGS:

1) $T R, M V, P S$ : POWER SW. OFF.

2) TR: READ/WRITE Sw. to READ.

3) RC: TRANSPORT/DISABLE Sw. to DISABLE.

4) RC: DATA/TTY/1130 Sw, to DATA.

5) IF: INTERRUPT/DISABLE Sw. to DISABLE.

III. POWER ON:

1) PS: RACK POWER Sw. ON.

2) TR: POWER SW. ON.

3) MV: POWER SW. ON.

4) PS: POWER SUPPLY SW. ON. 
IV. READY MULTIVFRTER:

1) AP: Connect analog inputs from left to right.

2) MV: Select number of channels to be converted on OCTAL CHANNEL SELECT Sw. (Switch Settings = Number - 1; e.g., 7 channels $=006)$.

3) MV: Turn NORM/CALIBRATE Sw. from. NORM to CALIBRATE, and then back to NORM.

4) CV: Check to see that FRAME SYNC Light is on. If not, cycle NORM/CALIBRATE Sw. (MV) until it comes on.

V. REMOVE DIGITAL TAPE (if necessary):

1) RC: FAST FCRWARD/REWIND Sw. to REWIND.

2) TR: Make sure tape is properly threaded.

3) TR: Engage Tape Reel Servos by gently rocking upper reel CCW.

4) TR: Push REWIND button; the tape should rewind. If a reflective marker is encountered the tape may stop. Push REWIND again.

5) TR: Remove upper tape reel by unscrewing rectangular Ree1 Lock (CCW) and pulling tape reel from hub.

VI. LOAD DICITAL TAPE:

1) Install tape reel on upper hub. Hold tape reel firmly on hub while turning rectangular Reel Lock CW to lock reel to hub.

2) TR: Thread tape directly onto lower reel in a CW fashion. (Moisture on end of tape readily assures that tape end will adhere to lower reel).

3) TR: Put 3-4 turns of tape onto the lower reel.

4) TR:. Draw out 2-3 feet of tape between the reels.

5) TR: Gently drape the tape over the white tape guide on the upper tension arm - WITHOUT MOVING IT!?! 
6) TR: Thread the tape properly through the tape guides, heads and capstans.

7) TR: Guide the tape around the lower tension arm and take up the slack with the lower reel.

8) TR: ENGAGE TAPE SERVOS by gently rocking upper reel CCW.

9) TR: Push READ button.

10) TR: Push and hold down LOAD FORWARD button until the tape advances to the first reflective marker, at which time the READ Sw. will disengage and the forward motion will stop.

VII. ADVANCE TAPE PAST PREVIOUSLY WRITTEN FILES (if necessary):

1) RC: Set FAST FORWARD/REWIND Sw. to FAST FORWARD.

2) TR: Push REWIND button. Tape should advance in forward direction.

3) RC: Push STOP button prior to the end of the files to be skipped.

4) RC: Change DATA/TTY/1130 Sw. to 1130.

5) IF: Push STOP and RESET.

6) TR: Set READ SPEED Sw. to 30 IPS.

7) RC: Set TRANSPORT/DISABLE Sw. to TRANSPORT to engage capstans.

8) IF: Push FORWARD REC. button. The tape should advance to an Inter-Record Gap (IRG). If it doesn't stop within a few seconds hit STOP on the 1130 Interface (IF). The written portion of the tape has been passed over and it will be necessary to backspace to the File Marks by pushing BACKWARD FILE.

9) IF: If the tape did stop at an IRG in step 8, push FORWARD FILE to reach the end of that File. It must be ascertained yet whether the FILE MARK is the last File Mark. By pushing. FORWARD REC, and observing the INTERFACE Lights, it is possible to know where the records and File Marks are. If more records are found past the initially found File Mark, it will be necessary to EORWARD FILE again. 
10) IF: Ultimately the end of the written area on the tape is found. At this point it will be necessary to BACKWARD FILE over the last File Mark as in Step 8. NOTE: The tape is now positioned for writing, but it is necessary to return the system electronics back to the state at which they were in Section VI, step 10.

11) RC: Set TRANSPORT/DISABLE Sw, to DISABLE.

12) RC: Push STOP to disengage the Kennedy READ Mode.

13) RC: IMPORTANT: Move DATA/TTY/1130 Sw. to TTY; the READ Mode will automatically come on in the Kennedy Transport.

14) RC: Disengage the READ Mode again by pushing STOP.

15) RC: Move DATA/TTY/1130 Sw. from TTY to DATA.

VIII. ENGAGE WRTTE MODE:

1) TR: Turn READ SPEED Sw. to 30 IPS.

2) TR: Turn READ/WRITE Sw. to WRITE.

3) TR: Push WRITE button, it should 1ight and the tape should advance.

4) TR: Insert appropriate number of File Marks by pushing the FILE GAP button. (See Section X, Step 4).

IX. READY CONVERTER SYSTEM:

1) CV: Connect up external sampling rate generator and select pulse rate. $(1,10$, and 60 pulses are avai1able on Power Supply).

2) CV: Push RESET COUNTERS and RESET ERRORS to clear converter. SYNC ERROR Light may remain ON.

3) TR: Set READ SPEED SW. to 10 or 30 IPS as desired.

4) CV: Set IPS Sw, to same setting (10 or 30 IPS) as transport. 
5) BM: Check that the ADDRESS and DATA switches on the BUFFER MEMORY are all DOWN.

6) CV: If the magnetic tape records are to be other than 4096 characters plus longitudinal check character, set the Record Length Switches immediately behind the Converter Front Panel to appropriate positions.

7) RC: Set TRANSPORT/DISABLE Sw. to TRANSPORT.

X. CONVERTING DATA.

1) : Start Analog Input. (E.g., with an FM Tape Recorder start Playback.)

2) CV: Push START.

3) CV: Push STOP when sufficient ANALOG DATA has been converted.

4) TR: Insert File Marks by pushing the FILE GAP button. Three File Marks are suggested at the beginning of new tapes. Two file marks are suggested between files. It is also suggested that three file marks be written at the end of the last file. If that is done, then two file marks will always appear between adjacent files: the BACKWARD FILE discussed in Sec. VII, Steps 8) and 10) will stop the tape between the second and third file marks and subsequent writing of a new file will overwrite the third file mark leaving only two file marks between files.

File Mark surmary:

a) 3 at beginning of new tape.

b) none at completion of sec. VII.

c) 2 between files.

d) 3 at completion of data conversion. *kr.

5) TR: Return READ SPEED Sw, to appropriate position for further conversion. 